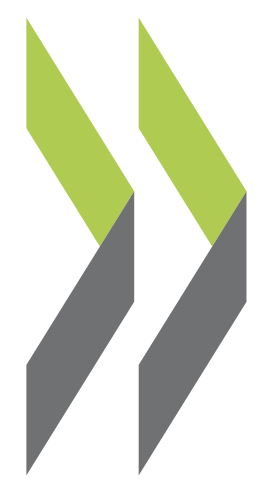

OECD Economics Department Working Papers No. 1488

An empirical investigation on the drivers of income redistribution across OECD countries

Orsetta Causa, Anna Vindics, Oguzhan Akgun 
ECONOMICS DEPARTMENT

\section{AN EMPIRICAL INVESTIGATION ON THE DRIVERS OF INCOME REDISTRIBUTION ACROSS OECD COUNTRIES}

\section{ECONOMICS DEPARTMENT WORKING PAPERS No. 1488}

\section{By Orsetta Causa, Anna Vindics and Oguzhan Akgun}

OECD Working Papers should not be reported as representing the official views of the OECD or of its member countries. The opinions expressed and arguments employed are those of the author(s).

Authorised for publication by Alain de Serres, Deputy Director, Policy Studies Branch, Economics Department.

All Economics Department Working Papers are available at www.oecd.org/eco/workingpapers.

JT03434582 
OECD Working Papers should not be reported as representing the official views of the OECD or of its member countries. The opinions expressed and arguments employed are those of the author(s).

Working Papers describe preliminary results or research in progress by the author(s) and are published to stimulate discussion on a broad range of issues on which the OECD works.

Comments on Working Papers are welcomed, and may be sent to OECD Economics Department, 2 rue André-Pascal, 75775 Paris Cedex 16, France, or by e-mail to eco.contact@oecd.org.

All Economics Department Working Papers are available at www.oecd.org/eco/workingpapers.

This document and any map included herein are without prejudice to the status of or sovereignty over any territory, to the delimitation of international frontiers and boundaries and to the name of any territory, city or area.

The statistical data for Israel are supplied by and under the responsibility of the relevant Israeli authorities. The use of such data by the OECD is without prejudice to the status of the Golan Heights, East Jerusalem and Israeli settlements in the West Bank under the terms of international law.

On 3 May 2018, the OECD Council invited Lithuania to become a Member. At the time of preparation the deposit of Lithuania's instrument of accession to the OECD Convention was pending and therefore Lithuania does not appear in the list of OECD Members and is not included in the OECD zone aggregates.

On 25 May 2018, the OECD Council invited Colombia to become a Member. At the time of preparation the deposit of Colombia's instrument of accession to the OECD Convention was pending and therefore Colombia does not appear in the list of OECD Members and is not included in the OECD zone aggregates.

(C) OECD (2018)

You can copy, download or print OECD content for your own use, and you can include excerpts from OECD publications, databases and multimedia products in your own documents, presentations, blogs, websites and teaching materials, provided that suitable acknowledgment of OECD as source and copyright owner is given. All requests for commercial use and translation rights should be submitted to rights@oecd.org 


\section{ABSTRACT/RESUMÉ \\ An empirical investigation on the drivers of income redistribution across OECD countries}

This paper provides an empirical investigation on the drivers of tax and transfer income redistribution to working-age households across the OECD over the last two decades, in a context where it has been declining in the vast majority of countries. The analytical approach is based on a reduced-form model of income redistribution which is estimated through cross-country-time series regressions. The baseline model builds on the political economy literature of income redistribution and includes a set of non-policy drivers such as labour market and socio-demographic conditions as well as measures of globalisation and technological change. The baseline model is augmented with major direct policy drivers of income redistribution covering tax revenue and social spending as well as a selection of tax and transfer policy parameters. Changes in the size of the tax and transfer systems likely to have contributed to the decline in income redistribution include the decline in social spending on cash support for working-age population and the diminishing role of personal income taxes in reducing inequality under the effect of increasing trade openness. Changes in specific tax and transfer policy instruments and parameters likely to have contributed to the decline in income redistribution include a flattening of the tax schedule in the upperpart of the wage distribution, a decline in the generosity and duration of unemployment-related transfers, including cuts to social assistance, and pension and early retirement reforms to encourage longer working life.

JEL codes: D31, H23, H53, I38.

Keywords: income inequality, redistribution, taxes, transfers, progressivity.

$* * * * * * * * * * *$

\section{Une analyse empirique au sujet des déterminants de la redistribution des revenus par les impôts et les transferts dans les pays de l'OCDE}

Ce document présente une étude empirique des déterminants de la redistribution des revenus via taxes et transferts dans la population d'âge actif des pays de l'OCDE au cours des vingt dernières années, période pendant laquelle celle-ci a diminué dans la majorité des pays. L'approche analytique est basée sur l'estimation en panel de la forme réduite d'un modèle de redistribution. Ce modèle est fondé sur la littérature d'économie politique de la redistribution et inclut un ensemble de déterminants non directement liés aux politiques de taxes et transferts, tels que les conditions sur le marché du travail et sociodémographiques ainsi que des mesures de globalisation et changement technique. Le modèle de base est ensuite augmenté avec ensemble de déterminants politiques majeurs de la redistribution, incluant les recettes fiscales et les dépense sociales mais également une sélection de paramètres spécifiques associés aux différents instruments de taxes et transferts. Les changements associés au budget fiscal de redistribution ayant contribué à réduire celle-ci incluent la baisse de la dépense sociale vis-à-vis de la population d'âge actif et le moindre effet égalisateur de l'impôt sur le revenu sous l'effet d'une intégration commerciale croissante. Les changements associés aux instruments et paramètres fiscaux spécifiques ayant contribué à réduire la redistribution incluent : une moindre progressivité de l'impôt sur le revenu vis-à-vis des ménages plus aisés, une diminution de la générosité et de la durée des indemnités chômage -- y compris des coupes dans les indemnités d'assistance --, et les réformes de systèmes de retraite et pré-retraites visant à encourager l'allongement de la vie active.

Codes JEL : D31, H23, H53, I38.

Mots clés : inégalités de revenu, redistribution, taxes, transferts, progressivité. 


\section{Table of contents}

\section{An empirical investigation on the drivers of income redistribution across OECD countries ........ 6}

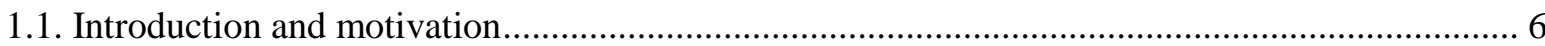

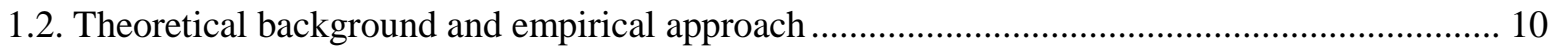

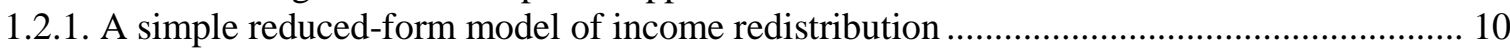

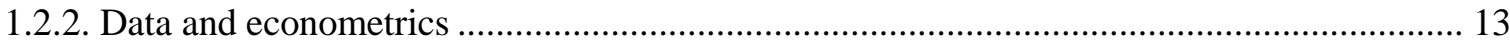

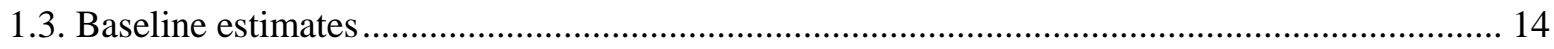

1.3.1. The labour market and the socio-demographic composition of working-age households ... 14

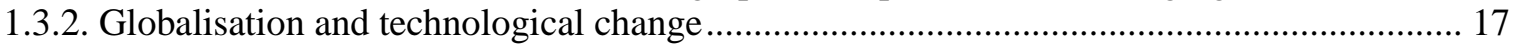

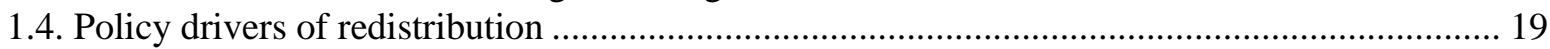

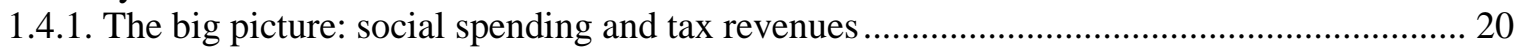

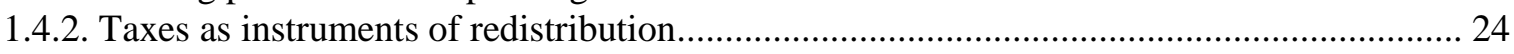

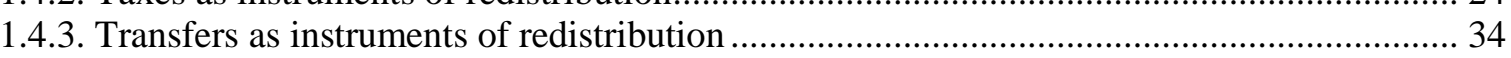

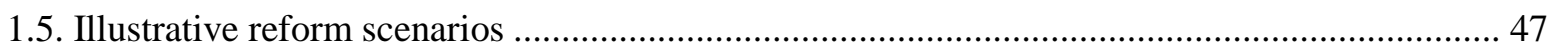

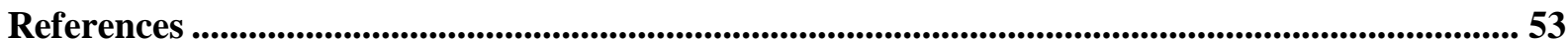

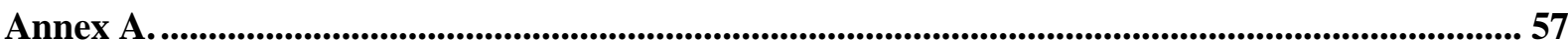

\section{Tables}

Table 1. Redistribution: the effects of labour market conditions and the socio-demographic composition

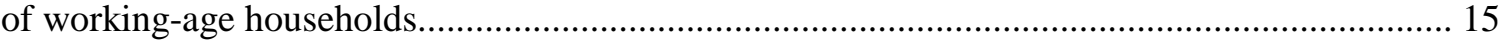

Table 2. Redistribution: the effects of technological change and globalization .................................... 18

Table 3. Redistribution: the effects of social spending and tax revenues........................................... 21

Table 4. Taxes and redistribution: a focus on the overall progressivity of personal income taxes on wage

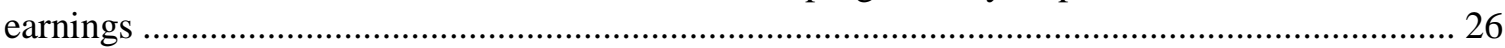

Table 5. Taxes and redistribution: a focus on top tax rates and on the taxation of capital income ....... 31

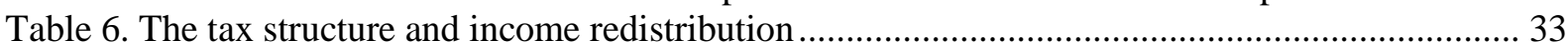

Table 7. Transfers and redistribution: A focus on unemployment-related transfers ............................. 36

Table 8. Transfers and redistribution: A focus on public policies for families and children ................ 41

Table 9. The effects of old-age pension systems and early retirement incentives on redistribution to the working-age population.

\section{Figures}

Figure 1. Redistribution has declined for almost all available OECD countries since the mid-1990s.... 8 Figure 2. The interaction between trade openness and the size of PIT in shaping income redistribution24 Figure 3. Developments in the progressivity of personal income taxes between 2000 and 2015, OECD average.

Figure 4. Net unemployment benefit replacement rates for low-income married couples across OECD countries 
Figure 5. Public spending on early childhood education and care: developments across OECD countries

Figure 6. Reform-driven changes in redistribution for the working-age population. 43

Figure 7. Illustrative income redistribution effects of selected transfer reforms. 50 52 


\title{
An empirical investigation on the drivers of income redistribution across OECD countries
}

\author{
By Orsetta Causa, Anna Vindics and Oguzhan Akgun ${ }^{1}$
}

\subsection{Introduction and motivation}

Over the past decades, household incomes have become more unequally distributed in most OECD countries. ${ }^{2}$ Rising income inequality has not only been driven by soaring top income shares, but also by a tendency for lower-income households to fall behind relative to the rest of the population. While the size, timing and characteristics of rising inequalities vary across OECD countries, rising wage dispersion and in a number of countries increasing job polarization are common features. ${ }^{3}$ Such disequalising forces are not likely to disappear in a still uncertain future of digitalisation and prolonged technological change. This poses a great challenge to governments' fiscal redistribution through taxes and transfer systems, all the more in a context where new forms of work are questioning the effectiveness of traditional social safety nets and population ageing is putting pressure on the redistributive capacity of government's budgets.

Work has been going on for a long time, not least at the OECD, to shed light on the distributional effects of pro-growth structural reforms. ${ }^{4}$ This has allowed for integrating distributional and more broadly, inclusiveness objectives in policy analysis and recommendations. ${ }^{5}$ By contrast, evidence-based analysis on the distributional (and growth) effects of pro-equity reforms (in particular of tax and transfer reforms) is scarcer, at least from a cross-country comparative perspective. Yet, tax and transfer systems are

\footnotetext{
${ }^{1}$ The authors are members of the Economics Department of the OECD. They are grateful to Isabelle Wanner for research assistance and to Faustin Schneider for important contributions during the initial steps of the empirical work. They would like to thank colleagues James Browne, Michael Förster, Herwig Immervoll and Horacio Levy from the OECD Employment, Labour and Social Affairs directorate for collaboration and discussions on this paper. They thank Pierce O'Reilly from the Center for Tax Policy Analysis for sharing the data on tax progressivity and Christian Geppert for the sharing the data on old-age pension parameters. They would also like to thank OECD Economics Department colleagues Alain de Serres, Luiz de Mello, Dorothée Rouzet, Nicolas Ruiz and participants in the Working Party No. 1 of the Economic Policy Committee, participants in the Employment, Labour and Social Affairs Committee for useful comments and suggestions.

2 OECD (2016; 2015; 2011).

${ }^{3} \operatorname{OECD}(2011,2016)$.

${ }^{4}$ See for inter aliia Chapter 2 of OECD (2011) and Causa et al. (2015, 2016).

${ }^{5}$ For example in Going for Growth (OECD, 2017a).
} 
fundamental pillars of an inclusive growth policy agenda that aims at sharing the benefits of growth more equally and securing decent living standards for those in most need.

This paper aims at addressing this important knowledge gap by providing an empirical investigation on the drivers of income redistribution through taxes and transfers. Redistribution is quantified as the relative reduction in market income inequality achieved by personal income taxes, employees' social security contributions and cash transfers, based on household-level micro data. As income inequality is quantified by the Gini coefficient, the redistributive effect of taxes and transfers is defined as the difference between the Gini coefficient of household market incomes and the Gini coefficient of household disposable incomes. This is measured in relative terms, that is, in percentage of the market income Gini coefficient. This normalisation allows for taking into account cross-country differences in the initial level of market income inequality.

This approach has been widely used in the literature as it provides a method for assessing income redistribution in a cross-country comparative perspective. However, it also comes with limitations, most of which are data-driven. The data do not allow for adopting a lifecycle perspective. For this reason, the analysis is centred on interpersonal redistribution among the working-age population, so as to largely exclude retired households relying on pension transfers. Moreover, the data does not include wider instruments of redistribution such as in-kind public services and subsidised employment. Ongoing progress in data construction reconciling micro-sources with the system of national accounts should make it possible to address some of these limitations in future work.

Prior to this paper, related work by Causa and Hermansen (2017) has taken stock of the extent to which tax and transfer systems mitigate market income inequality among the working-age population today, and how this has changed over the last two decades of rising globalisation and technological change. The paper shows a widespread decline in redistribution across the OECD, both on average and in the majority of countries for which data going back to the mid-1990s are available (Figure 1), confirming and extending previous findings by Immervoll and Richardson (2011). Such decline was primarily associated with a decline in cash transfer redistribution while personal income taxes played a less important and more heterogeneous role across countries. In turn, the decline in the redistributive effect of cash transfers reflected a decline in their size and in particular by less redistributive insurance transfers. In some countries, this was mitigated by more redistributive assistance transfers but the resulting increase in the targeting of total transfers was not sufficient to prevent transfer redistribution from declining. 
Figure 1. Redistribution has declined for almost all available OECD countries since the mid1990s

Change in redistribution for the working-age population

A. Mid-1990s to 2015 or latest available year

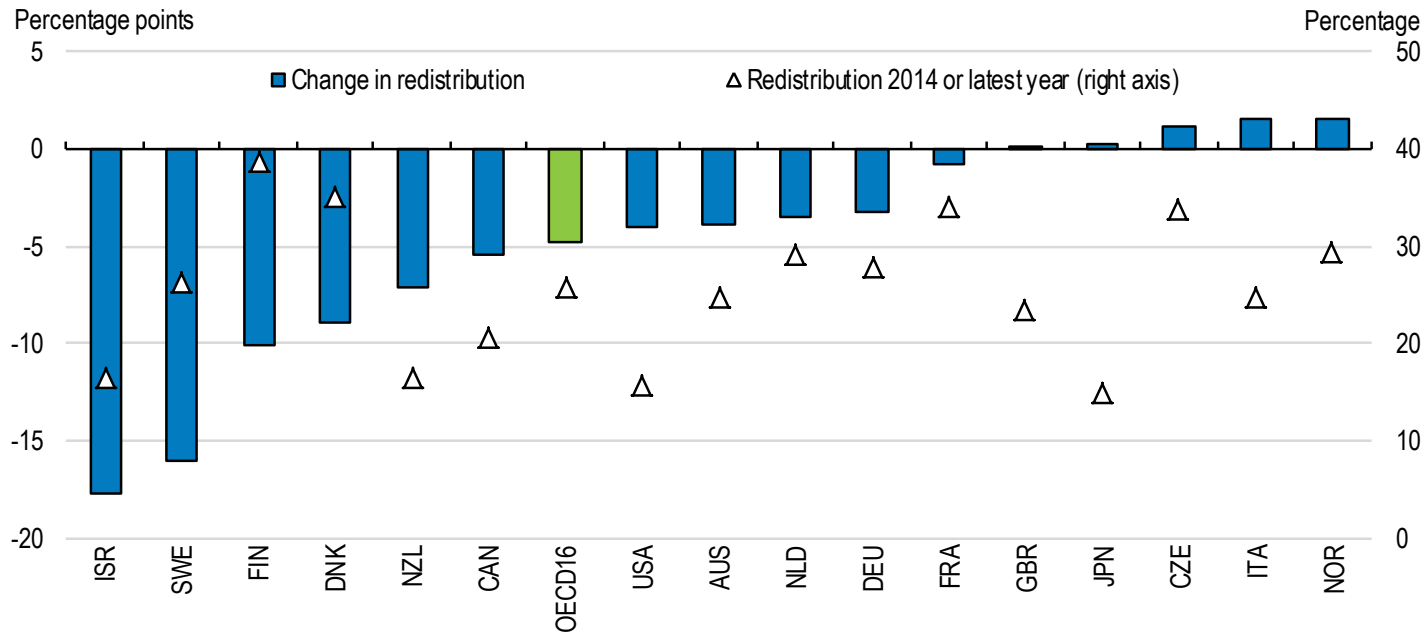

B. Mid-2000s to 2015 or latest available year

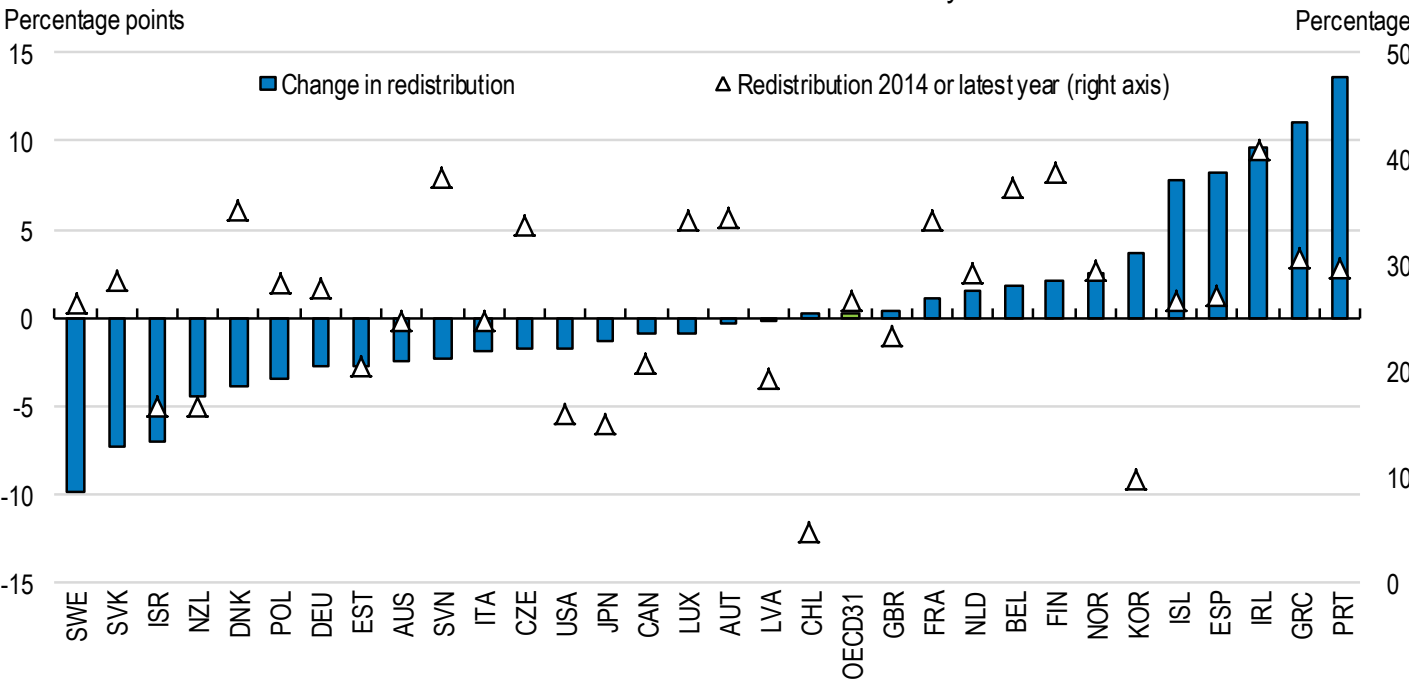

Note: Measured redistribution for Hungary, Mexico and Turkey only captures the impact of cash transfers because of data limitations which makes the results less comparable to the other OECD countries. For Panel A data refer to 1994-2015 for the United Kingdom; 1995-2012 for Japan; 1995-2015 for Finland, Israel, the Netherlands and the United States; 1996-2014 for Czech Republic and France; and 1995-2014 for the rest. For Panel B data refer to 2003-2012 for Japan; 2003-2014 for New Zealand; 2004-2015 for Finland and the United Kingdom; 2005-2014 for Denmark, France and Poland; 2005-2015 for Israel, the Netherlands and the United States; 2006-2015 for Chile and Korea; and 2004-2014 for the rest. See text and Causa and Hermansen (2017) for further details on redistribution measure and working-age population.

Source: OECD Income Distribution Database.

The finding of a widespread decline in income redistribution across OECD countries is striking and calls for further investigation. Indeed, this finding captures the combined impact of: i) discretionary policy changes; ii) changes induced by structural forces such as demography and household composition as well as globalisation, technology and the 
nature of work and; iii) changes in economic conditions, in particular in the extent of unemployment. The objective of this paper is to investigate the relative contribution of these various drivers. This is achieved by regression analysis covering developments in redistribution for the working-age population over the last decades and attempting to identify major drivers of redistribution among a broad set of structural and policy factors. A complementary and companion paper by Browne and Immervoll (2018) addresses the same question by microsimulation analysis, covering a more recent period and isolating the effect of tax and transfer reforms from other effects (i.e. by holding the distribution of market incomes and population structure constant).

This paper delivers the following main findings on the major drivers of income redistribution to working-age households, in a context where it has declined in most OECD countries since the mid-1990s:

- Changes in the size of the tax and transfer systems likely to have contributed to the decline in income redistribution include: i) the relatively widespread decline in social spending on cash support for working-age population and ii) the diminishing role of personal income taxes in reducing inequality, under the effect of increasing trade openness.

- Changes in specific tax and transfer policy instruments and parameters likely to have contributed to the decline in income redistribution include:

- The decline in the progressivity of personal income taxes, driven by a flattening of the tax schedule in the upper-part of the wage distribution as well as by a decline in top personal income tax rates and in the taxation of dividend income at the personal level.

- The decline in the generosity and duration of unemployment-related transfers, including cuts to social assistance for the long-term unemployed, in combination with an increase in spending on active labour market policies.

- The reforms of pensions to encourage a longer working life, for instance increases in the age of full pension eligibility and/or reductions in replacement rates.

- The impact of these factors has been partly mitigated by progressive family-friendly policies, such as widespread increases in spending on early education and childcare, as well as by tax cuts to low wage earners.

- Policy results are used to simulate the income redistribution effect of selected tax and transfer reform scenarios, taking into account of countries' relative starting point in each policy area:

- Tax reforms to increase the progressivity of personal income taxes, top marginal tax rates and the taxation of dividend income at the personal level would deliver large redistribution gains in countries that feature close to flat PIT systems, such as Eastern European countries.

- Transfer reform to increase cash transfers for long-term unemployed as well as public support on early education and childcare would deliver major redistribution gains, especially in countries that exhibit relatively high levels of child poverty such as the United States and Turkey.

The rest of this paper is organised as follows. Section 2 briefly introduces the empirical approach based on relevant theoretical background underscoring the choice of a simple 
reduced-form model of income redistribution. Section 3 delivers baseline estimates, starting with fundamental drivers, i.e. labour market and socio-demographic conditions; then uncovering the role of structural trends such as globalisation and technological change. Section 4 augments baseline estimates to investigate the role of policies in the area of taxes and transfers, starting with their size and then going more granular into their design. Building on selected empirical estimates, Section 5 produces some illustrative simulations of specific policy reform scenarios to make tax and transfer systems more effective at mitigating income inequality.

\subsection{Theoretical background and empirical approach}

\subsubsection{A simple reduced-form model of income redistribution}

The simple reduced-form model of income redistribution builds on the large literature on inequality reduction and the political economy of income redistribution. In this respect, one key point is that redistribution can change in the absence of changes to tax and transfer policy settings, in particular due to: i) conditions on the labour market e.g. the prevalence of unemployment, and ii) socio-demographic conditions e.g. the prevalence of single parent families or families with children, especially if workless. The intuition is simple and as follows. When unemployment goes up, redistribution is likely to increase even with constant benefit amount per jobseeker, simply because more people claim unemployment benefits. This points to the fact that part of taxes and transfers act as publicly-provided risk insurance schemes, not only as redistributive schemes. When the share of families with children goes up, especially if this is associated with income vulnerability because of joblessness, redistribution is also likely to increase in the presence of mandated minimum cash support for such families, which is the case in just about all advanced countries. The baseline model of income redistribution therefore systematically includes the unemployment rate (and, as robustness check, additional cyclical variables). The analysis also investigates the impact of socio-demographic household composition; along with the potential indirect effect of population ageing on redistribution to the working-age population.

The baseline model also includes various measures and components of market income inequality, in particular earnings inequality. Changes in market income inequality are largely driven by unemployment, but also by changes in the level and structure of earnings inequality ${ }^{6}$. In fact, while rising unemployment is consensually found to translate into rising redistribution, rising market income and earnings inequality are not. The link between inequality before taxes and transfers and redistribution is a longstanding controversial question in the welfare state and political science literature ${ }^{7}$. Early studies have attempted to validate the canonical model associated with Romer (1975) and Melzer and Richard (1981) - the so-called RMR model - according to which income redistribution should increase with market income inequality. Most studies have found a weak relation and some have found that the opposite holds: governments in countries

\footnotetext{
${ }^{6}$ Other drivers pertain to capital income. This important aspect is not investigated in this paper as it would require an accurate coverage of top incomes and an accurate assessment of capital income, which is not possible with the data at-hand but is possible with administrative or registerbased data. See Piketty et al. (2016) .

${ }^{7}$ See Esping-Andersen and Myles (2009) in the Handbook of Economic Inequality
} 
with relatively higher market income dispersion tend to engage in relatively less income redistribution ${ }^{8}$; leading to the so-called "Robin-Hood paradox" firstly introduced by Lindert (2004).

Various explanations have been put forward to explain why rising market income inequality does not systematically translate into rising income redistribution. One argument is that social transfer systems are designed to serve not only the objective of "static" redistribution defined as inequality reduction but also that of lifecycle redistribution defined as individual insurance against certain risks such as unemployment, sickness and disability. To the extent that the demand for insurance relative to redistribution differs across income groups and in particular that it increases with income, more market income inequality can translate into less redistribution ${ }^{9}$. Another argument is that the rise in inequality gives the rich more power to fight off demands for redistribution and the way in which they do this is to put resources into persuading people that incentives are very important which translates into a decline in the demand for redistribution ${ }^{10}$. Finally, partisans of the so-called "power resource theory"11 argue that the inequality-reducing effect of taxes and transfers depends on a range of mediating political economy factors that shape the supply of redistribution, such as government partisanship, union power and voter turnout ${ }^{12}$. As a result, the baseline model investigates the effect of some political drivers in addition to that of earnings inequality.

The model includes measures of globalisation, building on an extensive literature on the subject. ${ }^{13}$ Two broad hypotheses have been put forward: the efficiency hypothesis predicts that globalisation induces tax competition hence a downward pressure on mobile factors tax rates and a shift in the tax burden from capital to labour, ultimately eroding government size and capacity to finance the welfare state. By contrast, the compensation hypothesis (Rodrik, 2011) predicts that globalisation increases the size of government and in particular social spending by increasing workers' demand for compensation against risk arising from rising exposure to international economic forces; to which governments respond by expanding social safety nets. Empirical evidence is relatively consensual in finding that globalisation has not been associated with a decline in the overall size of governments and social spending. However, evidence on the effects of globalisation on

\footnotetext{
${ }^{8}$ E.g. Alesina and Glaeser (2004). Previous work found that among OECD countries, those with a more unequal distribution of market income tend to redistribute more (Joumard et al., 2012), but relying on a non-standard redistribution measure (see above). Such assessment is generally sensitive to the countries included and the redistribution measure.

9 Moene and Wallerstein (2001, 2003); Andersen (2015). Of course, the redistributive and insurance functions are often related and the two aspects not so easy to disentangle.

${ }^{10}$ Georgiadis and Manning (2007) provide empirical support for this argument on the basis of UK data covering the 1983-2004 period. See Inequality and redistribution: why such a weak link? VOX, CEPR's Policy Portal.

${ }^{11}$ See e.g. Esping-Andersen and Myles (2009); Bradley et al. (2003); Kenworthy and Pontusson (2005); Swank (2015); Iversen and Soskice (2006).

${ }^{12}$ See e.g. Alesina and Glaeser (2004). Other political arguments pertain to governments' capture: in unequal societies, the rich are able to buy enough political power to buy regressive fiscal policies, see Acemoglu and Robinson (2007, 2012).

${ }^{13}$ See Potrafke, (2015), and Meinhard and Potrafke, (2012).
} 
tax policy is mixed, not least because the numerous studies on the subject have relied on a wide array of data and empirical approaches. ${ }^{14}$

The effect of technological change is analysed alongside that of globalisation. Studies on the link between technological change and market income, especially wage inequality and the labour share of income, are numerous and tend to find dis-equalising effects, due notably to rising skill premia and declines in routine-tasks occupations. However, the evidence on disposable income inequality is more mixed, while it is non-existent when it comes to the impact on income redistribution. ${ }^{15}$

The model attempts to uncover the link between non-standard work and income redistribution. Indeed, many non-standard workers (in particular the self-employed) are not covered by traditional social protection systems. Therefore, an increase in the share of such workers may imply a decline in income redistribution. However such analysis faces statistical and analytical obstacles: i) existing data is relatively poor and measuring nonstandard work in a harmonised way across countries over time is still only work-in progress, and ii) non-standard workers are heterogeneous in a non-distributionally neutral way (earnings levels), which implies that for a given incidence of non-standard work, compositional differences are likely to have an impact on redistribution outcomes.

This model is then augmented with major direct policy drivers of income redistribution. The analysis starts by introducing macroeconomic tax revenue and social spending variables, and then moves to uncover the effects of more granular redistribution instruments and tax/transfer policy parameters such as net unemployment benefit replacement rates or personal income tax rates at various points of the distribution. A key distinction is to be made between the estimated effects of those tax/transfer instruments that are included in the redistribution measure used as the dependent variable, that is, personal income taxes, employees' social security contributions and cash transfers to the working-age population; and those that are not, such as consumption and property taxes; as well as in-kind transfers and transfers to the old-age population. The latter effects have a less clear interpretation than the former.

Keeping this limitation in mind, one example of a potentially relevant question on the tax side is that of the redistributive effect of a growth-oriented tax reform, e.g. a revenueneutral shift from personal income taxes to consumption and property taxes. In the context of ageing societies, another potentially relevant question on the transfer side is that of the effect of social spending on old-age population on redistribution to the working-age population.

The estimation of a reduced-form model of redistribution implies that it is not possible to identify the respective role of "mechanical" as opposed to "second-round" effects of taxes and transfers on income redistribution. ${ }^{16}$ Indeed, taxes and transfers cause changes in

${ }^{14}$ One of the latest studies on this topic relies on instrumental variable approach and shows that globalisation has induced a shift from firm-borne to employee-borne taxes and an increase in relative tax burdens on the broad middle class relative to the very-high and very-low income earners (Egger et al. 2016).

15 On the effects of globalisation on wage inequality and the labour share, see OECD (2011), Berlingieri et al. (2017), OECD (2017b), Schwellnus et al. (2017). On skilled-biased technological change and routinisation, see Card and Di Nardo (2002), Acemoglu and Autor (2011).

${ }^{16}$ See Figari et al. (2015), Bourguignon and Spadaro (2006). 
market prices and household behaviour, hence can affect the difference between market and disposable income through effects on the distribution of both market and disposable incomes. Behavioural effects can be relevant in particular because tax and transfer reforms are often motivated by the primary objective of encouraging labour supply, rather than redistributing income. For example, a tightening of unemployment benefits to encourage job search will "mechanically" reduce redistribution but, if successful, such reform will also reduce market income inequality. The empirical approach in this paper will capture the combination of these two effects on income redistribution.

\subsubsection{Data and econometrics ${ }^{17}$}

The empirical analysis is based on country-level panel data regressions covering OECD countries from the early 1990 s to the latest available year. The dependent variable, natural logarithm of income redistribution through taxes and transfers among working-age households $\ln (R E)$, is based on the OECD Income Distribution Database (IDD). The IDD covers all OECD countries, but for a number of them the data do not start before the mid2000s. In addition, the data are not available on a yearly basis over the 1990s while they usually are after the mid-2000s. The option of interpolating the missing data is ruled out in order to avoid artificially narrowing the standard errors; and also with a view to exploiting the variance to identify long-term effects. As detailed in the Appendix, the explanatory variables are sourced in various databases, mostly produced at the OECD, in particular regarding taxes and transfers. ${ }^{18}$ The estimation is based on the following empirical model:

$\ln (R E)_{i t}=\beta^{\prime} Z_{i t}+\delta_{1}{ }^{\prime} S_{i t}+\delta_{2}{ }^{\prime} P_{i t}+\alpha_{i}+\lambda_{t}+\epsilon_{i t}$

, where $Z_{i t}$ includes non-policy variables such as the labour market and sociodemographic conditions, $S_{i t}$ includes measures of the size of the tax and transfer system and $P_{i t}$ includes selected policy parameters of tax and transfer systems. $\alpha_{i}$ and $\lambda_{t}$ are country and year fixed effects, respectively. Country fixed effects are included not only to reduce the risk of time-invariant omitted variable bias, but also to focus on countries' developments in income redistribution rather than cross-country differences in the levels of income redistribution. ${ }^{19}$ All the regressions also include year fixed effects. ${ }^{20}$ In the baseline case this model is estimated using within estimator with period dummies.

\footnotetext{
${ }^{17}$ See Appendix for data sources and definitions.

${ }^{18}$ Some relevant explanatory variables are only available for a relatively recent period (starting in e.g. 2000): such is the case of income tax progressivity indicators from the OECD Taxing Wages dataset; as well as net unemployment benefit replacement rates indicators from the OECD Tax and Benefit dataset. These variables are not discarded from the analysis because they convey granular measurement of tax and transfer systems. However, the short nature of the panel in such cases should be kept in mind when interpreting the regression results.

19 For comparison purposes, baseline estimates without fixed effects are also reported in the appendix at the end of the paper.

${ }^{20}$ These effects are, more precisely, period fixed effects because IDD data are not available on a yearly basis over the nineties which implies that time dummies initially refer to several years (e.g. 1990-1994) and then refer to single years (e.g. from 2005 to latest observation).
} 
Standard errors are clustered at the country level. ${ }^{21}$ The results are robust when tested against a battery of sensitivity tests discussed in the Appendix. Still, caution is needed in interpreting the results of this empirical exercise: there is no pretention to identify causal relationships. The idea is rather to provide an indication of what have been the important proximate drivers of income redistribution across OECD countries over the last decades.

\subsection{Baseline estimates}

\subsubsection{The labour market and the socio-demographic composition of working- age households}

The estimates strongly confirm the major influence of labour market conditions in driving redistribution to working-age households (Table 1). ${ }^{22}$ In particular, changes in unemployment rates are found to be the primary labour market drivers of changes in redistribution within countries, while changes in the incidence of long-term unemployment or in employment rates have no additional significant effects (columns 13 ). The data indicate that the responsiveness of automatic stabilizers decrease with the level of unemployment. For example, as persistently high unemployment increases its long-term incidence, redistribution no longer increases as long-term unemployed lose access to insurance-base unemployment transfers. ${ }^{23}$ Taken at face value, the estimates imply that an increase in unemployment of $10 \%$ is associated with an increase in income redistribution of around $2 \%$. This effect is largely cyclical, in the sense that changes in redistribution respond relatively closely to changes in unemployment, as illustrated in Causa and Hermansen (2017).

${ }^{21}$ Fixed effects are included for countries where the redistribution measure from the IDD only refers to transfers (Hungary, Mexico and Turkey), which becomes irrelevant when the focus is on the within-country variation.

${ }^{22}$ This is in line with descriptive analysis in Causa and Hermansen (2017) and Immervoll and Richardson (2011); as well with regression-based analysis such as Swank (2015), Huber and Stephens (2014) and Moene and Wallerstein (2003).

${ }^{23}$ This intuition is tentatively confirmed by comparing Table 1, based on within-country estimates (with country fixed effects), with table A4 in the appendix, based on simple OLS estimates (without country fixed effects): while the former results suggest that the rate of unemployment is the most important labour market driver of redistribution, the latter suggest that it is the incidence of long-term unemployment. 
Table 1. Redistribution: the effects of labour market conditions and the socio-demographic composition of working-age households

\begin{tabular}{|c|c|c|c|c|c|c|c|c|c|c|c|c|c|c|c|c|c|}
\hline Dependent variable is $\ln$ (redistribution) & 1 & 2 & 3 & 4 & 5 & 6 & 7 & 8 & 9 & 10 & 11 & 12 & 13 & 14 & 15 & 16 & 17 \\
\hline \multicolumn{18}{|l|}{ Labour market conditions } \\
\hline In (Unemployment rate) & $\begin{aligned} 0.24^{* * *} & (0.04)\end{aligned}$ & $\begin{array}{l}0.25^{* \star *} \\
(0.05)\end{array}$ & $\begin{aligned} 0.25^{* * *} \\
(0.06)\end{aligned}$ & $0.24^{\star \star \star}$ & $0.24^{\star \star \star}$ & $0.24^{\star \star \star}$ & $0.23^{\star \star \star}$ & $0.24^{\star \star \star}$ & $0.22^{\star \star \star}$ & $0.18^{\star * *}$ & $0.19^{\star \star \star}$ & $0.18^{\star \star \star}$ & $0.18^{\star \star}$ & & & $0.17^{\star \star \star}$ & $0.18^{* * *}$ \\
\hline \multirow{2}{*}{ Long-term unemployment } & & -0.03 & & & & & & & & & & & & & & & \\
\hline & & $(0.17)$ & & & & & & & & & & & & & & & \\
\hline \multirow[t]{2}{*}{ Employment rate } & & & 0.17 & & & & & & & & & & & & & & \\
\hline & & & $(0.62)$ & & & & & & & & & & & & & & \\
\hline \multicolumn{18}{|l|}{ Demographic and socioeconomic conditions } \\
\hline \multirow[t]{2}{*}{ Youth dependency rate } & & & & -0.50 & & -0.61 & & & & & & & & & & & \\
\hline & & & & $(0.84)$ & & $(0.87)$ & & & & & & & & & & & \\
\hline \multirow{2}{*}{ Old-age dependency rate } & & & & & 0.66 & 0.73 & & & & & & & & & & & \\
\hline & & & & & $(0.89)$ & $(0.94)$ & & & & & & & & & & & \\
\hline \multirow{2}{*}{ Share of lone parents among working-age households } & & & & & & & 1.89 & & & & & & & & & & \\
\hline & & & & & & & $(1.29)$ & & & & & & & & & & \\
\hline \multirow[t]{2}{*}{ Share of families with children among working-age households } & & & & & & & & -0.55 & & & & & & & & & \\
\hline & & & & & & & & $(0.49)$ & & & & & & & & & \\
\hline \multirow[t]{2}{*}{ Share of workless families with children among working-age households } & & & & & & & & & $0.85^{\star \star *}$ & $1.88^{\star *}$ & 1.42 & $2.22^{\star \star}$ & $0.77^{\star \star \star}$ & $4.65^{\star \star *}$ & $1.06^{\star \star \star}$ & 1.44 & 1.43 \\
\hline & & & & & & & & & $(0.21)$ & $(0.85)$ & $(0.89)$ & $(0.95)$ & $(0.21)$ & $(0.91)$ & $(0.32)$ & $(0.90)$ & $(0.94$ \\
\hline \multicolumn{18}{|l|}{ Income inequality before taxes and transfers } \\
\hline \multirow{2}{*}{ Earnings inequality: $\ln (\mathrm{d} 9 \mathrm{~d} 1)$} & & & & & & & & & & $-0.50^{\star \star \star}$ & & & & $-0.63^{\star \star \star}$ & & $-0.52^{* *}$ & \\
\hline & & & & & & & & & & $(0.15)$ & & & & $(0.17)$ & & (0.25) & \\
\hline \multirow{2}{*}{ Earnings inequality:In (d9d5) } & & & & & & & & & & & $-0.70^{\star \star \star}$ & & & & & & \\
\hline & & & & & & & & & & & $(0.22)$ & & & & & & \\
\hline \multirow[t]{2}{*}{ Earnings inequality: $\ln (\mathrm{d} 5 \mathrm{~d} 1$ ) } & & & & & & & & & & & & $-0.68^{\star \star \star}$ & & & & & \\
\hline & & & & & & & & & & & & $(0.25)$ & & & & & \\
\hline \multirow[t]{2}{*}{ Gini market income } & & & & & & & & & & & & & 0.78 & & $2.38^{\star \star \star}$ & & \\
\hline & & & & & & & & & & & & & $(0.95)$ & & $(0.50)$ & & \\
\hline \multicolumn{18}{|l|}{ Government partisanship and union power } \\
\hline \multirow[t]{2}{*}{ Left-wing gov. parties' seat share } & & & & & & & & & & & & & & & & $5.70^{\star}$ & $5.18^{*}$ \\
\hline & & & & & & & & & & & & & & & & $(3.00)$ & $(2.84$ \\
\hline \multirow[t]{2}{*}{ Union density } & & & & & & & & & & & & & & & & 0.44 & $0.62^{*}$ \\
\hline & & & & & & & & & & & & & & & & $(0.33)$ & $(0.31$ \\
\hline Voter turnout & & & & & & & & & & & & & & & & $\begin{aligned}-0.11 \\
(0.12)\end{aligned}$ & $\begin{array}{l}-0.16 \\
(0.12\end{array}$ \\
\hline Time fixed effects & Yes & Yes & Yes & Yes & Yes & Yes & Yes & Yes & Yes & Yes & Yes & Yes & Yes & Yes & Yes & Yes & Yes \\
\hline Country fixed effects & Yes & Yes & Yes & Yes & Yes & Yes & Yes & Yes & Yes & Yes & Yes & Yes & Yes & Yes & Yes & Yes & Yes \\
\hline Observations & 380 & 371 & 380 & 380 & 380 & 380 & 380 & 380 & 380 & 362 & 362 & 362 & 380 & 362 & 381 & 300 & 311 \\
\hline R squared & 0.41 & 0.41 & 0.41 & 0.41 & 0.41 & 0.42 & 0.42 & 0.41 & 0.42 & 0.44 & 0.43 & 0.44 & 0.43 & 0.35 & 0.37 & 0.47 & 0.45 \\
\hline
\end{tabular}

Note: Dependent variable is the natural logarithm of redistribution. Standard errors are clustered at the country level. R squared does not incorporate the effect of country fixed effects. Significance levels: $* \mathrm{p}<.1 ; * * \mathrm{p}<.05 ; * * * \mathrm{p}<.01$

Bold highlights significant coefficients 
Demographic conditions, in particular the old-age and youth dependency rates are found to have no statistically significant effect on redistribution to working-age households (columns 4-6) ${ }^{24}$. Thus, the data do not corroborate the intuitive assumption that the pressure from ageing and the subsequent need to finance pension obligations would have been major drivers of the decline in redistribution to working-age households observed in the majority of OECD countries over the period under consideration. One reason may be the concomitant increasing reliance on private pension systems which has indeed been fundamentally driven by the need to ensure the sustainability of public pension systems.

By contrast with pure demographic conditions, the results indicate significant effects from sociodemographic conditions defined by the interplay between joblessness and household structure: rising proportions of workless families with children among working-age households are associated with rising redistribution, and this effect applies over and above that of unemployment (column 9). This result is likely to reflect that a number of social transfers, in particular social assistance, are often designed to protect children from income hardship, implying stronger generosity towards families with children. While the share of lone parents among working-age households is not statistically significant (column 7), an alternative measure based on the share of children living with a single parent is positively and significantly associated with redistribution. The latter is consistent with findings from previous papers. ${ }^{25}$ However, using this alternative variable reduces the sample size and hence is not retained in the baseline. ${ }^{26}$

Earnings inequality is strongly negatively associated with income redistribution to working-age households. This result is robust and holds across various earnings inequality measures (columns 10-12). Taken at face value, the estimates imply that a rise in the wage gap between the top and bottom of the distribution by $10 \%$ would be associated with a decline in redistribution by $5 \%$. Such an increase in the wage dispersion has been quite common across the OECD and has been seen, for instance, in Finland between 2000 and 2013 and in Italy between 2011 and 2014. By contrast with earnings inequality, market income inequality, a more comprehensive measure of inequality before taxes and transfers but very likely to be endogenous in this empirical setting, is not found to have a statistically significant effect on income redistribution (column 13). Further inspection strongly suggests that this is driven by the presence of unemployment in the model: when unemployment is not controlled for, market income inequality has a significant positive effect of income redistribution (column 15). By contrast, the effect of earnings inequality holds regardless of the presence of unemployment in the model (column 14).

\footnotetext{
${ }^{24}$ The analysis of demographic variables has been much more extensive than what is reported here yet consistently inconclusive which is why no more results are shown in the paper. For example, similar non-significant results are obtained by using very granular data on the age structure of total and working-age populations. Also, similar non-significant results are obtained by using projected old-age dependency ratios based on the idea that governments would react to future pressures.

${ }^{25}$ For example Huber and Stephens (2015).

${ }^{26}$ Results not reported but available upon request. The data on the share of children living with a single parent is from the OECD Family Database.
} 
The redistributive effect of union power (here proxied by union density) ${ }^{27}$ is positive only when the model does not control for earnings inequality. The effect is not significant conditional on earnings inequality (columns $16 \& 17$ ). This is consistent with the idea that the inequality-reducing effect of unions is channelled through their influence on wage dispersion rather than on income redistribution through taxes and transfers. ${ }^{28}$ Voter turnout is not found to trigger a significant effect on redistribution. This is contrary to early studies but is in line with most recent ones. ${ }^{29}$ By contrast, there is some evidence of a significant redistributive effect from government left partisanship, as measured by leftwing government parties' seat share, though the coefficient is not precisely estimated (column 17). This is a relevant result in line with number of political science studies on redistribution. However, the partisanship control variable will not be further included in the subsequent regressions because this reduces the already- small sample size. ${ }^{30}$

\subsubsection{Globalisation and technological change}

Increased economic integration is found to increase income redistribution through taxes and transfers. This result holds across a variety of globalisation measures (Table 2): from largely available "traditional" measures, i.e. openness, imports and exports (columns 1-3), to more sophisticated ones that better reflect the current nature of trade through countries' integration in global value chains, i.e. the share of imported value added in final domestic demand (column 4). The disadvantage with the latter measure is that it substantially reduces the sample as it is available only over a shorter time period. The broad finding that rising economic integration is associated with rising redistribution is in line with the majority of comparable empirical studies, as discussed before along the lines of the socalled "compensation hypothesis". ${ }^{31}$

\footnotetext{
${ }^{27}$ The same result holds with union coverage.

${ }^{28}$ It is also in line with other empirical papers such as Huber and Stephens (2015).

${ }^{29}$ For example, Lupu and Pontusson (2011).

${ }^{30}$ Including this variable does not change the qualitative findings of this paper.

${ }^{31}$ See Potrafke (2015) for a recent survey. For example, most recently Egger et al (2016), Tanninen et al (2017); earlier studies include Kwon and Pontusson (2010), Lupu and Pontusson (2011), Meinhard and Potrafke (2012), Dreher (2005), Rodrik (1998), Onaran and Boesch (2014), Gemmel et al (2008). See also Potrafke (2009) for a study on the effect of globalisation on partisan politics.
} 
Table 2. Redistribution: the effects of technological change and globalization

\begin{tabular}{|c|c|c|c|c|c|c|c|}
\hline Dependent variable is $\ln$ (redistribution) & 1 & 2 & 3 & 4 & 5 & 6 & 7 \\
\hline \multicolumn{8}{|l|}{ Technological change \& Globalisation } \\
\hline \multirow[t]{2}{*}{ In (openness) } & $0.20^{\star \star}$ & & & & $0.21^{\star *}$ & $0.25^{\star}$ & $0.20^{\star \star}$ \\
\hline & $(0.09)$ & & & & $(0.09)$ & $(0.14)$ & $(0.07)$ \\
\hline \multirow[t]{2}{*}{ In (exports) } & & $0.21^{\star \star}$ & & & & & \\
\hline & & $(0.10)$ & & & & & \\
\hline \multirow[t]{2}{*}{ In (imports) } & & & $0.12^{\star}$ & & & & \\
\hline & & & $(0.07)$ & & & & \\
\hline \multirow[t]{2}{*}{ In (imported value added to final demand) } & & & & $0.26^{\star \star \star}$ & & & \\
\hline & & & & $(0.07)$ & & & \\
\hline \multirow{2}{*}{ In (migration inflows share of working-age population) } & & & & & 0.02 & & \\
\hline & & & & & $(0.03)$ & & \\
\hline \multirow[t]{2}{*}{ In (migration stock by nationality share of working-age population) } & & & & & & $-0.02^{\star \star}$ & \\
\hline & & & & & & $(0.01)$ & \\
\hline \multirow[t]{2}{*}{ In (MFP change) } & $-0.51^{\star \star}$ & $-0.58^{\star \star \star}$ & $-0.42^{\star \star}$ & $-0.44^{\star \star}$ & $-0.50^{\star \star}$ & $-0.59 * \star \star$ & -0.23 \\
\hline & $(0.19)$ & $(0.20)$ & $(0.20)$ & $(0.20)$ & $(0.22)$ & $(0.21)$ & $(0.19)$ \\
\hline \multicolumn{8}{|l|}{ Changes in the nature of work } \\
\hline \multirow[t]{2}{*}{ Share of temporary employment in total employment } & & & & & & & -0.33 \\
\hline & & & & & & & $(0.54)$ \\
\hline \multicolumn{8}{|l|}{ Labour market, sociodemographic conditions and earnings inequality } \\
\hline \multirow[t]{2}{*}{ In (Unemployment rate) } & $0.15^{\star \star \star}$ & $0.12^{\star \star \star}$ & $0.17^{\star \star \star}$ & $0.21^{\star \star \star}$ & $0.16^{\star \star \star}$ & $0.13^{\star \star \star}$ & $0.17^{\star \star \star}$ \\
\hline & $(0.03)$ & $(0.03)$ & $(0.04)$ & $(0.04)$ & $(0.03)$ & $(0.03)$ & $(0.04)$ \\
\hline \multirow[t]{2}{*}{ Earnings inequality: $\ln (\mathrm{d} 9 \mathrm{~d} 1$ ) } & $-0.49^{\star \star \star}$ & $-0.45^{\star \star \star}$ & $-0.51^{\star \star \star}$ & $-0.64^{\star \star \star}$ & $-0.47^{\star \star \star}$ & $-0.65^{\star \star \star}$ & $-0.46^{\star \star \star}$ \\
\hline & $(0.15)$ & $(0.15)$ & $(0.15)$ & $(0.18)$ & $(0.17)$ & $(0.16)$ & $(0.16)$ \\
\hline \multirow[t]{2}{*}{ Share of workless families with children among working-age households } & 1.43 & 1.47 & 1.57 & 0.28 & 1.37 & 1.31 & $2.18^{\star \star}$ \\
\hline & $(0.98)$ & $(0.94)$ & $(0.98)$ & $(0.87)$ & $(0.99)$ & $(1.18)$ & $(0.99)$ \\
\hline Time fixed effects & Yes & Yes & Yes & Yes & Yes & Yes & Yes \\
\hline Country fixed effects & Yes & Yes & Yes & Yes & Yes & Yes & Yes \\
\hline Observations & 357 & 357 & 357 & 254 & 345 & 302 & 319 \\
\hline R squared & 0.48 & 0.49 & 0.47 & 0.53 & 0.48 & 0.48 & 0.49 \\
\hline
\end{tabular}

Note: Dependent variable is the natural logarithm of redistribution. Standard errors are clustered at the country level. R squared does not incorporate the effect of country fixed effects. Significance levels: * $\mathrm{p}<.1 ; * * \mathrm{p}<.05 ; * * * \mathrm{p}<.01$

Bold highlights significant coefficients 
The effects from increased migration are less clearly identified than those from increased trade openness (not least because of a reduction in sample size), but would tend to suggest a very small negative effect on redistribution. The measure that relates migration inflows to the working-age population has no significant effects on redistribution (column 5). Meanwhile, the one that relates migration stocks to the working-age population has a significant negative effect on redistribution, yet based on a reduced sample (column 6). Taken at face value, the estimates would imply that an increase in the share of migrants' stock to the working age population by $10 \%$ would imply a decrease in redistribution by $0.2 \%$.

The finding that a rising proportion of migrants in the working-age population may lead to a decline in redistribution is consistent with the fact that migrants, especially recentlyarrived, are less likely to benefit from comparable levels of social protection than natives, either because they are not entitled (for example because of shorter employment tenure) or because they are not claiming the transfers they are entitled to (for example because of lack of information). Thus, these results do not support the so-called "welfare magnet" hypothesis (Borjas, 1999) according to which migrants would be attracted by countries that exhibit more generous welfare states. However, the migration variable will not be included in the subsequent regressions because this reduces the already- small sample size. $^{32}$

By contrast with economic integration, technological change, as proxied by total factor productivity growth, is found to influence negatively income redistribution. This result cannot be benchmarked to existing theoretical and empirical literature on redistribution due to the lack of comparable studies. One channel of interpretation is that technological change tends to increase market income inequality via a number of channels such as rising wage inequality due to rising skill premia, rising non-standard work and declining labour shares $;{ }^{33}$ and that taxes and transfers fail to fully compensate for such technologydriven disequalising effects. The analysis fails to find any significant effect of rising nonstandard work on redistribution, although the sign is negative as expected (column 7). Also, adding this variable to the model does not alter the effect of wage inequality. Using the share of temporary employment in total employment is the best available, yet a far from perfect proxy of non-standard work. ${ }^{34}$

\subsection{Policy drivers of redistribution}

This section presents the empirical analysis of major policy drivers of redistribution. In a first stage, the model is augmented with broad macro-based measures of the size of tax and transfer redistribution, that is, tax revenue and social spending variables. In a second stage, the model is again augmented with more granular and specific instruments of redistribution, that is, tax and transfer policy parameter variables. The separation between

\footnotetext{
${ }^{32}$ Including this variable does not change the qualitative findings of this paper.

${ }^{33}$ See OECD (2017b, 2018b).

34 An accurate measure of non-standard work should cover a variety of labour relationships patterns which are difficult to portray in a single and comparable measure with sufficient time series. See OECD $(2015,2018 b)$.
} 
tax and transfer instruments allows for better structuring the analysis and the presentation of the results but is somewhat artificial. Income redistribution is the result of the interplay between a variety of taxes and transfers, but the limited size of the sample precludes from identifying the joint effect of a high number of policy variables. ${ }^{35}$

\subsubsection{The big picture: social spending and tax revenues}

The policy analysis starts by a simple investigation of the income redistribution effects of fiscal deployment through taxes and transfers, conditional on the various non-policy drivers of redistribution, in particular unemployment and earnings inequality. Proper quantification of the effects of macro-based tax and spending variables on redistribution comes close to automatic stabilisers analysis which is not the focus of this project. The quantitative estimates should then be taken with caution because of potential endogeneity bias due to the cyclical nature of redistribution. Regressions systematically include the unemployment rate and the robustness of results is tested via the inclusion of additional measures of the economic cycle as well as by lagging macro-based tax and spending variables. ${ }^{36}$

Two types of fiscal deployment variables are introduced:

- Tax revenue and social spending variables coinciding with the fiscal instruments included in the redistribution measure; namely social spending on cash support to working-age population and tax revenue from PIT and employees' SSC.

- Tax revenue and social spending variables going beyond the fiscal instruments included in the redistribution measure, that is, total social spending and total tax revenue. These variables measure the actual overall size of the tax and transfer system. Their inclusion allows for coming closer to fiscally-neutral policy scenarios ${ }^{37}$ when introducing specific policy instruments in the regressions.

The results presented in Table 3 suggest that the size of the redistribution system plays a major role for income redistribution, in particular on the spending side, confirming findings in Causa and Hermansen (2017) as well as in Immervoll and Richardson (2011):

35 That said, in practice, a number of policy parameter variables used in the empirical analysis already encompass both taxes and transfers: for example unemployment-related transfer measures which are studied in the transfer section are net of taxes payable on such transfers.

${ }^{36}$ See appendix for robustness analysis.

${ }^{37}$ Fiscal neutrality here pertains to tax revenue and social spending and not to the overall size of government. Controlling for the overall size of government is doable but it is not an advisable option for the purpose of this paper as it would dilute the analysis from income redistribution and make the interpretation much more tentative. 
Table 3. Redistribution: the effects of social spending and tax revenues

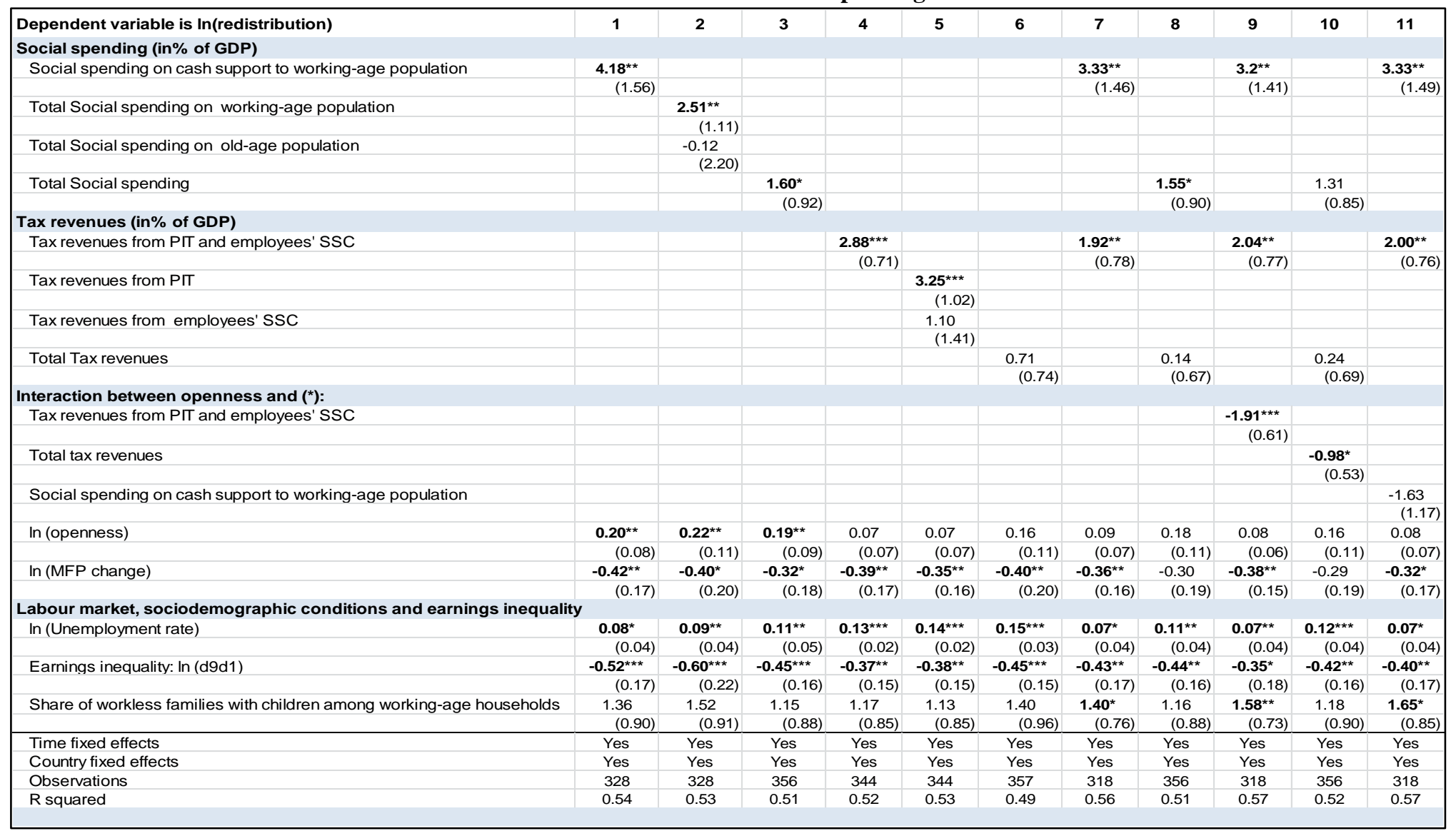

Note: Dependent variable is the natural logarithm of redistribution. Standard errors are clustered at the country level. $(*)$ every variable in the interactions is demeaned. R squared does not incorporate the effect of country fixed effects.

Significance levels: $* \mathrm{p}<.1 ; * * \mathrm{p}<.05 ; * * * \mathrm{p}<.01$

Bold highlights significant coefficients. 
- Social spending on cash support to the working-age population is found to have the strongest redistributive effect, with an increase in spending of 1 percentage GDP point being associated with an increase of around $4 \%$ in redistribution (column 1). This effect seems to be largely driven by the deployment of unemployment-related automatic stabilisers associated, as suggested by the fact that the elasticity of redistribution to unemployment is almost reduced by one-half when social spending on cash support to the working-age population is included.

- Tax revenue raised from personal income taxes and employees' SSC is also found to have a strong redistributive effect, with an increase in revenue of 1 percentage GDP point being associated with an increase of around $3 \%$ in redistribution (column 4). This effect is driven by personal income taxes which are confirmed to be major instruments of tax redistribution (column 5), whereas the effect of employee SSC is not statistically significant, consistent with evidence showing that SSC have little redistributive effect and in fact are regressive in number of countries. $^{38}$

- Total social spending on working-age population, which encompasses cash but also in-kind transfers, is also positively associated with redistribution to the working-age population but the effect is smaller than that of spending on cash support alone (column 2). The effect of total social spending, which also covers spending on old-age population, remains positive but is less than the third of the effect social spending on cash support to the working-age population (column 3). The effect of social spending on old-age population is not statistically significant which can be interpreted as further confirmation of the failure to capture a significant negative effect from ageing-related fiscal pressure on income redistribution to working-age households. ${ }^{39}$

- Total tax revenue has a positive effect on redistribution to the working-age population but the estimate is not statistically significant (column 6) - it is statistically significant and large in the cross-section. ${ }^{40}$

Overall, these results confirm the prior that tax revenue and social spending variables coinciding with the fiscal instruments included in the redistribution measure, especially social spending on cash support to working-age population and tax revenue from PIT, have strong inequality-reducing effect. These findings hold when tax and social spending variables are entered jointly in the specification (columns 7 and 8) though the estimates show a small decline because of the high correlation between the fiscal variables.

Extending the analysis to uncover potential interactions between globalisation and income redistribution through fiscal deployment suggests that increased economic integration has tended to reduce the redistributive effect of tax revenues, and in particular of tax revenue raised from PIT and employees' SSC (columns $9 \& 10$ ). In other words, increased economic integration has made a given level of fiscal deployment through the

\footnotetext{
${ }^{38}$ Causa and Hermansen (2017), Immervoll and Richardson (2011).

39 A detailed breakdown of public social spending by age is not available in the SOCX Database. As standard practice, the measure for the old-age population is defined as the spending categories for old-age and survivors.

${ }^{40}$ Simple OLS results available on request.
} 
tax system less effective at reducing income inequality. This result is relevant as it is fully in line with recent research that has shown that: ${ }^{41}$ i) globalisation and international tax competition have put pressure on governments in OECD countries to shift taxation towards less mobile bases, and ii) this has been achieved mainly increasing the labour tax burden on the middle and upper-middle classes while reducing the burden on the top of the distribution - leading to a decline in the progressivity of PIT. By contrast with tax revenue, redistribution through social spending is not found to be affected by globalisation (column, 11), suggesting that the shaping of social policy is less directly influenced by the degree of exposure to external developments.

The finding of an interaction between economic integration and the size of the tax system in shaping income redistribution is tentatively illustrated in Figure 2(complemented in the Appendix). This figure shows the estimated marginal effect of PIT-to-GDP ratio on redistribution depending on countries' openness (Panel A) and conversely, that of openness on redistribution depending on countries' PIT-to-GDP ratio (Panel B). ${ }^{42}$ The figure points to strong non-linearities in the link between openness, PIT and redistribution:

- For around half of OECD countries, the effect of the PIT-to-GDP ratio on redistribution is significantly positive but this effect declines with openness levels. For a country at the OECD average level of trade openness, a one percentage point increase in the PIT-to-GDP ratio is associated with a $2 \%$ increase in redistribution. For the countries for which such effect is statistically significant, it ranges from $3.7 \%$ (USA) to around $1.5 \%$ (Korea)

- The positive effect of openness on redistribution fits well low-tax OECD countries, but not average and high-tax ones in which case the effect is not statistically significant. In fact, in countries that exhibit high PIT-to-GDP ratios such as Denmark, the estimated effect of trade openness is negative (although it is insignificant). For the low-tax countries for which such effect is statistically significant, its range is quite narrow: a $10 \%$ increase in trade openness increases redistribution from around 2\% (Slovakia) to around 1.2\% (Poland).

${ }^{41}$ Egger et al (2016). These findings are also largely in line with Martinez-Vazquez et al (2014) who similarly to us show that the effect of tax on inequality is "eroded" with openness.

${ }^{42}$ The appendix provides complementary cross-country scatters. 
Figure 2. The interaction between trade openness and the size of PIT in shaping income redistribution

Panel A. The effect of the size of PIT on redistribution decreases with trade openness

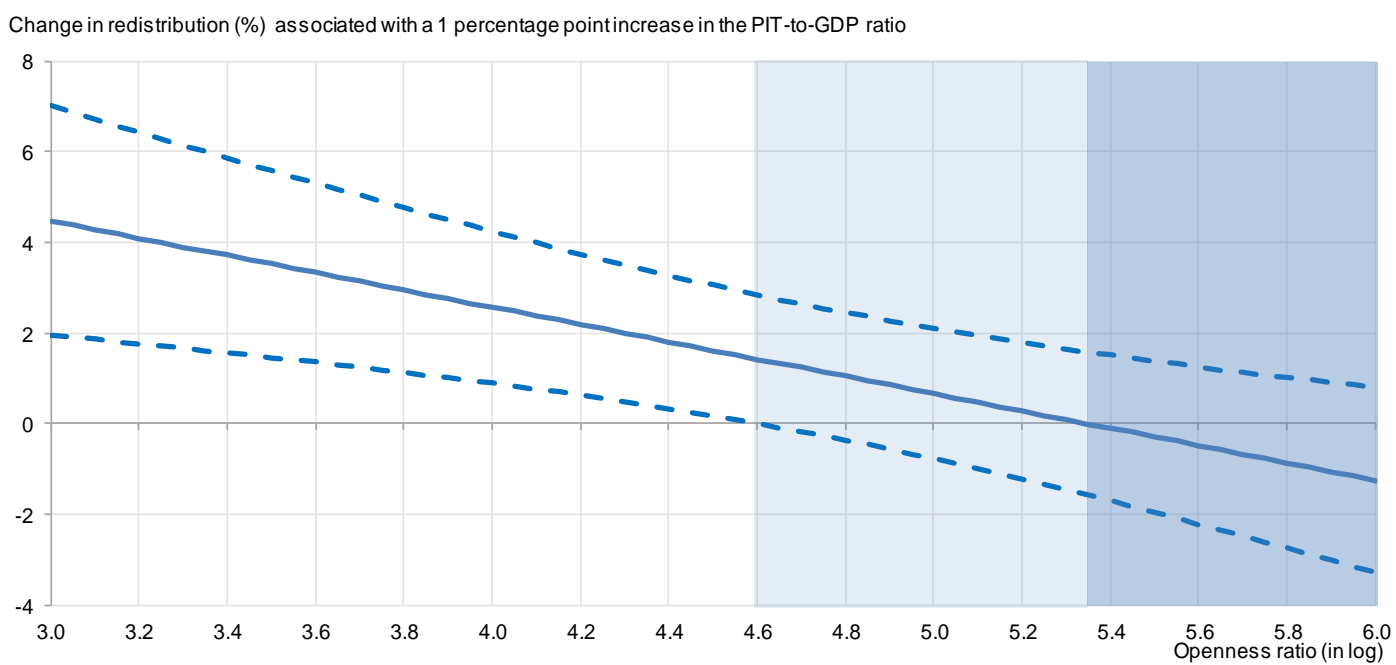

Panel B. The effect of trade openness on redistribution decreases with the size of PIT

Change in redistribution (\%) associated with a $1 \%$ increase in trade openness

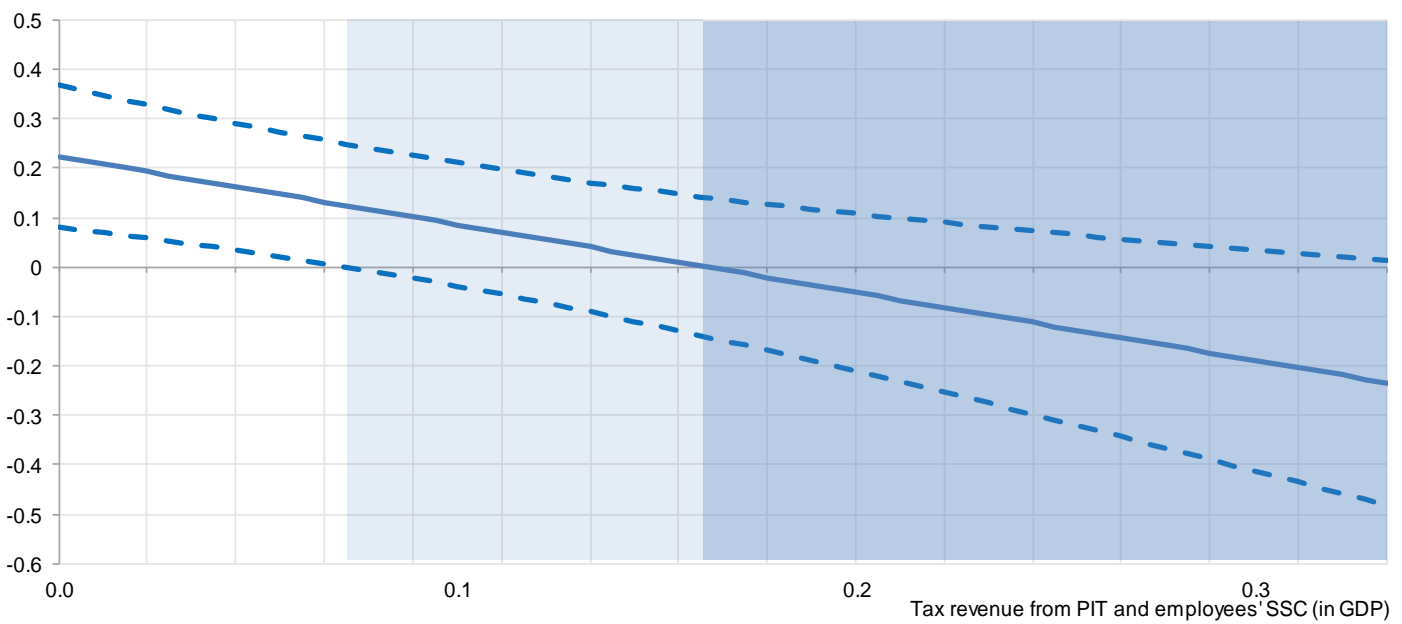

Note: The dashed lines indicate the $95 \%$ confidence interval. Light shading indicates a positive not significant effect and darker shading indicates a negative not significant effect. Tax-to-GDP ratio is tax on income and employees' SSC.

Source: Calculations are based on Table 3, column 9.

Overall, these results nuance the finding of a positive effect from globalisation on income redistribution and point to the potential challenge that increased economic integration poses for governments' capacity and effectiveness to deliver income redistribution through personal income taxes.

\subsubsection{Taxes as instruments of redistribution}

This section investigates the effect of selected parameters of the tax system that are likely to affect income redistribution. The focus is largely on personal income tax systems to be 
consistent with what is being measured as redistribution. ${ }^{43,44}$ The empirical model builds on the baseline and systematically controls for total tax revenue (as a share of GDP) so as to consider revenue-neutral policy scenarios. Regressions where both total tax revenue and tax revenue from PIT and employees' SSC are controlled for are reported in the Appendix. Policy parameter results are broadly unaffected when total tax revenue is interacted with openness, which is why for simplicity this interaction is not considered in what follows.

\section{The progressivity of personal income taxes on wage earnings $s^{45}$}

For a given size of the tax system, cross-country differences in income redistribution are strongly driven by differences in tax progressivity, as demonstrated in Causa and Hermansen (2017). Moving from descriptive to regression analysis confirms that the progressivity of PIT is an important driver of income redistribution both across countries but also within countries over time (Table 4, columns 1-4). This finding is based on a recently-developed overall structural tax progression indicator whereby progression is measured over the interval going from $50 \%$ of the average wage (AW) to $500 \%$ of the $\mathrm{AW} .^{46}$ The indicator measures how the average PIT rate increases per percentage point increase in labour income, measured as multiple of the AW, over the income interval. For example, a progression indicator of 0.10 (Germany, 2010) means that the personal average tax rate increases with 0.1 percentage points per percentage point increase in the average wage over the 50\%-500\% income level. The increase in the average PIT at 500\% of the AW compared to the rate at $50 \%$ of the AW then equals 0.1 multiplied by 450 , i.e. 45 percentage points. Taken at face value, the estimations imply that a decline in PIT progressivity by 1 standard deviation (of the current OECD distribution), which is equivalent to 0.06 , would be associated with a decline in redistribution by $2.15 \%$. This is close to the observed decline in in PIT progressivity in Norway between 2000 and 2006 and to 2015 difference in PIT progressivity between Sweden (0.097) and Poland (0.034).

\footnotetext{
${ }^{43}$ Employees' social SSC are also covered by the redistribution measure but they are not the focus here because : i) their redistributive effect is negligible, in fact in some countries they tend to be regressive (Causa and Hermansen, 2017), ii) a proper analysis of income redistribution through SSC should take into account both employers and employees SSC which is not possible with the redistribution measure at-hand, and, finally iii) a life-cycle perspective would ideally better uncover redistribution through SSC.

44 See Akgun et al (2017) for an analysis on the effect of the tax mix on disposable income inequality.

${ }^{45}$ In theory, the progressivity of the whole tax system should be assessed but in practice only PIT (and SSC) progressivity measures are available. At the same time PIT is the most powerful instrument of tax progressivity, not least due to its size (e.g. tax base and rates).

46 OECD, (2014), Special feature of Taxing Wages. In theory, the progressivity of the whole tax system should be assessed but in practice only PIT (and SSC) progressivity measures are available. At the same time PIT is the most powerful instrument of tax progressivity, not least due to its size (e.g. tax base and rates).
} 
Table 4. Taxes and redistribution: a focus on the overall progressivity of personal income taxes on wage earnings

\begin{tabular}{|c|c|c|c|c|c|c|c|c|c|c|c|c|c|c|c|c|c|}
\hline Dependent variable is $\ln$ (redistribution) & 1 & 2 & 3 & 4 & 5 & 6 & 7 & 8 & 9 & 10 & 11 & 12 & 13 & 14 & 15 & 16 & 17 \\
\hline \multicolumn{18}{|l|}{$\begin{array}{l}\text { Tax parameters } \\
\text { Procoressivity of personal income taxes (1) }\end{array}$} \\
\hline 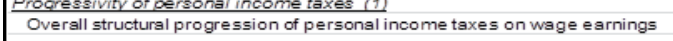 & $0.3^{3 * x}$ & $0.36 * x+3$ & $0.35^{*}$ & $0.35^{\star *}$ & & & & & & & & & & & & & \\
\hline Averace effective tax rates across the clistribution (1) & $(0.14)$ & $0.17)$ & $(0.14)$ & $(0.14)$ & & & & & & & & & & & & & \\
\hline Average effective tax rate at $67 \%$ of the $A W$ & & 1.07 & & 0.14 & 0.071 & 0.19 & 0.37 & 0.47 & 0.55 & 0.60 & 0.85 & 0.71 & 0.75 & 0.78 & 0.81 & 0.83 & 0.85 \\
\hline Average effective tax rate at $100 \%$ the AW & & & 1.38 & $1.28^{*} \cdot{ }^{(1)}$ & $1.32^{*}$ & 10.96 & $(0.99$ & $(1.00)$ & $(1.01)$ & $(1.02$ & $(1.03)$ & $(1.04)$ & $(1.05)$ & $(1.05$ & $(1.06)$ & (1.06) & $(1.07)$ \\
\hline & & & $(0.96)$ & $(0.67)$ & $(0.74)$ & & & & & & & & & & & & \\
\hline Average effective tax rate at $133 \%$ of the AW & & & & & & $1.33^{\star}$ & & & & & & & & & & & \\
\hline Average effective tax rate at $187 \%$ of the $\mathrm{AW}$ & & & & & & $(0.69)$ & & & & & & & & & & & \\
\hline & & & & & & & 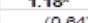 & & & & & & & & & & \\
\hline Average effective tax rate at $200 \%$ of the $\mathrm{AW}$ & & & & & & & 10.04 & $1.16^{*}$ & & & & & & & & & \\
\hline Average effective tax rate at $233 \%$ of the AW & & & & & & & & & & & & & & & & & \\
\hline 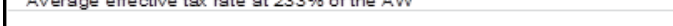 & & & & & & & & & $1.09^{\circ}=09 \mathrm{cos}$ & & & & & & & & \\
\hline Average effective tax rate at $287 \%$ of the $\mathrm{AW}$ & & & & & & & & & & $1.02^{*}$ & & & & & & & \\
\hline Average effective tax rate st $300 \%$ of the AW & & & & & & & & & & $(0.56$ & & & & & & & \\
\hline Average effective tax rate at $300 \%$ of the AW & & & & & & & & & & & 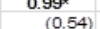 & & & & & & \\
\hline Average effective tax rate at $333 \%$ of the $\mathrm{AW}$ & & & & & & & & & & & & $0.98^{*}$ & & & & & \\
\hline Aversge effective tax rate at $367 \%$ of the $\mathrm{AW}$ & & & & & & & & & & & & & $0.91^{*}$ & & & & \\
\hline & & & & & & & & & & & & & $(0.48)$ & & & & \\
\hline Average effective tax rate at $400 \%$ of the AW & & & & & & & & & & & & & & 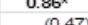 & & & \\
\hline Average effective tax rate at $433 \%$ of the $\mathrm{AW}$ & & & & & & & & & & & & & & & $0.81^{*}$ & & \\
\hline Average effective tax rate at $487 \%$ of the $\mathrm{AW}$ & & & & & & & & & & & & & & & $(0.48)$ & $0.79^{*}$ & \\
\hline & & & & & & & & & & & & & & & & & \\
\hline Avergas effective tax rate at $500 \%$ of the AW & & & & & & & & & & & & & & & & & 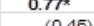 \\
\hline \multicolumn{18}{|l|}{ Tax revenues } \\
\hline Total Tax revenues (\% of GDP) & 0.45 & 0.23 & 0.18 & $\frac{0.17}{0.81}$ & 0.28 & $\frac{0.16}{0.79}$ & $\frac{0.17}{0.79}$ & 0.17 & \begin{tabular}{|l|l|}
0.19 \\
$0.79)$ \\
\end{tabular} & $\frac{0.22}{0.78}$ & 0.21 & $\frac{0.19}{0.79}$ & 0.2 & 0.2 & 0.2 & 0.19 & $\frac{0.19}{(0.79)}$ \\
\hline \multicolumn{18}{|l|}{$\begin{array}{l}\text { Technological change \& Globalisation } \\
\ln \text { (openness) }\end{array}$} \\
\hline In (openness) & $0.25 *$ & $0.19^{*}$ & $0.17^{\star}$ & $0.17^{*}$ & $0.16^{*}$ & $0.16^{*}$ & $0.17^{*}$ & $0.16^{*}$ & $0.17^{\star}$ & $0.17^{\star}$ & $0.17^{*}$ & $0.16^{*}$ & $0.17^{\star}$ & $0.17^{*}$ & $0.17^{*}$ & $0.17^{*}$ & $0.17^{*}$ \\
\hline In (MFP ohange) & -0.33 & -0.28 & -0.32 & -0.31 & -0.28 & -0.28 & -0.28 & -0.27 & -0.27 & -0.27 & -0.28 & -0.25 & -0.25 & -0.25 & -0.25 & -0.25 & 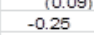 \\
\hline \multirow{2}{*}{\multicolumn{18}{|c|}{ 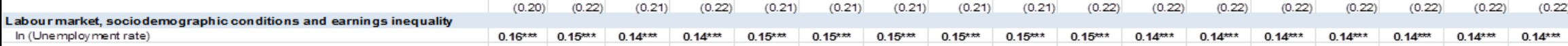 }} \\
\hline & $0.16^{+\infty}$ & $0.15^{+\infty x}$ & $0.14^{+\infty}$ & $0.14^{* \infty}$ & $0.15^{+* 0}$ & $0.15^{+*+\infty}$ & $0.15^{\circ+*}$ & $0.15^{+* 0+}$ & $0.15^{\tan x}$ & $0.15^{\circ * *}$ & 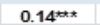 & $0.14^{+\infty x+2}$ & 0.14 & $0.14^{+3 x}$ & 0.14 & $0.14^{*+\infty}$ & $0.14^{*+\infty}$ \\
\hline Earnings inequality: $\ln (d 9 \mathrm{~d} 1)$ & \begin{tabular}{|c|c|c|}
$(0.04)$ \\
-0.4304
\end{tabular} & $\mid \begin{array}{ll}(0.03) \\
-0.42 *\end{array}$ & $-0.0 .03)$ & $\begin{aligned}(0.03) \\
-0.49+3\end{aligned}$ & $\frac{(0.03)}{-0.4903}$ & $\begin{array}{c}10.03 \\
-0.033^{203}\end{array}$ & $\frac{10.03}{-0.4703}$ & 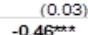 & $\begin{aligned}(0.03) \\
-0.45\end{aligned}$ & $\frac{0.03}{-0.055^{203}}$ & \begin{tabular}{|l|l|}
$(0.03)$ \\
-0.45
\end{tabular} & \begin{tabular}{|l|l}
$(0.03)$ \\
$-0.45 *$
\end{tabular} & $\frac{(0.03)}{-0.48+31}$ & $(0.03$ & $(0.03)$ & $(0.03)$ & \\
\hline Earrings inequality. in (asd) & $\mid-0.436)$ & $\frac{-0.42^{-2}}{(0.16)}$ & $(0.16)$ & -0.40 .17 & $\frac{-0.490 .17}{(17}$ & -0.40 .17 & -0.48 .16 & $-0.46 .16)$ & $-0.40 .16)$ & 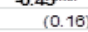 & $-0.40 .16)$ & $-0.40 .16)$ & $-0.440 .16)$ & $-0.44 .16)$ & $-0.44 .0 .16)$ & -0.44 & $-0.44^{(0.16)}$ \\
\hline Share of workless fanilies with children among working-age households & 1.30 & 1.42 & $1.50^{*}$ & 1.5 & 1.44 & 1.31 & 1.19 & 1.06 & 0.98 & 0.95 & 0.95 & 0.99 & 0.98 & 0.97 & 0.97 & 0.97 & 0.96 \\
\hline Time fixed effects & Yes & Yes & Yes & Yes & Yes & Yes & Yes & Yes & Yes & Yes & Yes & Yes & Yes & Yes & Yes & Yes & Yes \\
\hline 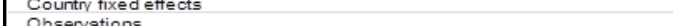 & 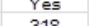 & $\frac{1}{315}$ & $\begin{array}{l}\text { Yes } \\
318\end{array}$ & 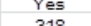 & $\begin{array}{l}\text { Yes } \\
302\end{array}$ & Yes & $\frac{r e}{3}$ & $\frac{1}{305}$ & 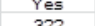 & $\frac{\text { Yes }}{302}$ & 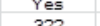 & $\begin{array}{l}\text { Yes } \\
302\end{array}$ & $\begin{array}{l}\text { Yes } \\
302\end{array}$ & 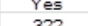 & $\begin{array}{l}\text { Yes } \\
302\end{array}$ & $\begin{array}{l}\text { Yes } \\
302\end{array}$ & $\begin{array}{lll}\text { Yes } \\
302\end{array}$ \\
\hline R squared & 0.48 & 0.48 & 0.49 & 0.49 & $0.48 \mathrm{P}>\mathrm{C}, \mathrm{C}$ & 0.49 & 0.49 & 0.49 & $0.49 \mathrm{P}>\mathrm{C}, \mathrm{C}, \mathrm{C}$ & 0.49 & 0.49 & $0.49 \mathrm{P}>\mathrm{C}, \mathrm{C}, \mathrm{C}$ & 0.49 & 0.49 & 0.49 & 0.49 & 0.49 \\
\hline
\end{tabular}

Note: Dependent variable is the natural logarithm of redistribution. Standard errors are clustered at the country level. R squared does not incorporate the effect of country fixed effects. (1) Data refer to single taxpayers without children.

$* p<1 * * * p<05 ; * * * p<.01$

Bold highlights significant coefficients 
To better understand this finding, the analysis attempts to uncover the relative effects of various average effective tax rates (AETR), i.e. across the whole wage interval, by piecewise steps. Because of multicollinearity between these variables, they cannot be entered altogether. Reflecting the definition of the overall progression indicator, the chosen approach is then to systematically control for the AETR at the bottom of the distribution and to successively introduce the various AETRs at higher income levels, from $100 \%$ to $500 \%$ of the AW (Table 4, columns 5-17). This would suggest that over this large interval, increasing AETRs, for constant PIT taxation at the bottom of the distribution, is significantly associated with an increase in income redistribution.

The coefficients are estimated as semi-elasticities and are all close to 1 , meaning that e.g. an increase in the AETR at $200 \%$ or $300 \%$ of the AW by 1 percentage point, keeping the AETR at the bottom of the distribution constant, would be associated with an increase in income redistribution by around $1 \%$. That said, the effects tend to decline as income rises, as the semi-elasticity is slightly higher than 1 around middle wages but slightly lower towards top wages. This may tentatively imply that increasing overall PIT progressivity by increasing taxation close to and slightly above the AW is more cost- effective than higher-up in the distribution. One reason could be that high-income individuals have greater incentives and resources to engage in tax planning, tax shifting (e.g. between labour and capital income) and tax avoidance in response to labour income tax increases; which implies that associated taxes may raise less revenue relative to taxes on middle wage earners. ${ }^{47}$

These findings are also consistent with descriptive evidence showing that over the last decades a number of tax reforms have involved an increase in the exemption threshold together with a lower top PIT rate, causing a shift in the tax burden from very low and very high incomes toward the middle. ${ }^{48}$ This pattern can be illustrated through the lenses of piecewise progressivity and AETR data (Figure 3). On average across the OECD, overall progressivity of PIT on wage earnings has tended to decline slightly, but piecewise progressivity has increased below the AW and decreased above the AW (Figure 3, Panel A). ${ }^{49}$ Going further, underlying piecewise AETR data indicate that these changes were driven by cuts in AETRs across all the income intervals, particularly so at the bottom and at the top, less so in the middle (Figure 3, Panel B). Tax cuts have therefore been regressive over a large portion of the distribution but not all of it. Still, the empirical estimates in this paper would suggest that overall (at least on average across the OECD), declines in PIT progressivity may have contributed to the decline in income redistribution. $^{50}$

\footnotetext{
${ }^{47}$ For evidence on tax planning and avoidance at the top of the distribution see Alstadsaeter et al (2017). See OECD Base erosion and profit shifting (BEPS) initiative. http://www.oecd.org/ctp/beps/.

${ }^{48}$ IMF (2017), Kim and Varsano (2008). This is in line with above-discussed results from Egger et al (2016).

${ }^{49}$ This is in line with Causa and Hermansen (2017).

${ }^{50}$ See also IMF $(2017,2018)$.
} 
Figure 3. Developments in the progressivity of personal income taxes between 2000 and 2015 , OECD average

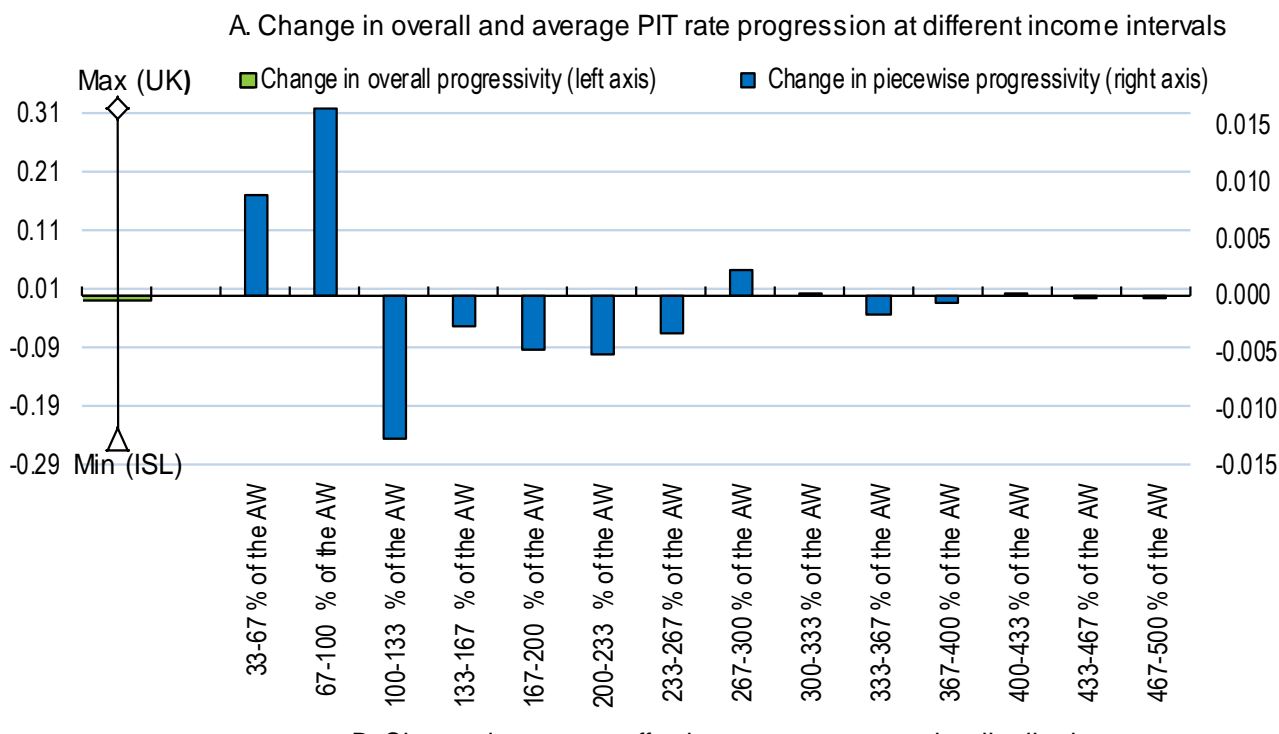

Percentage points

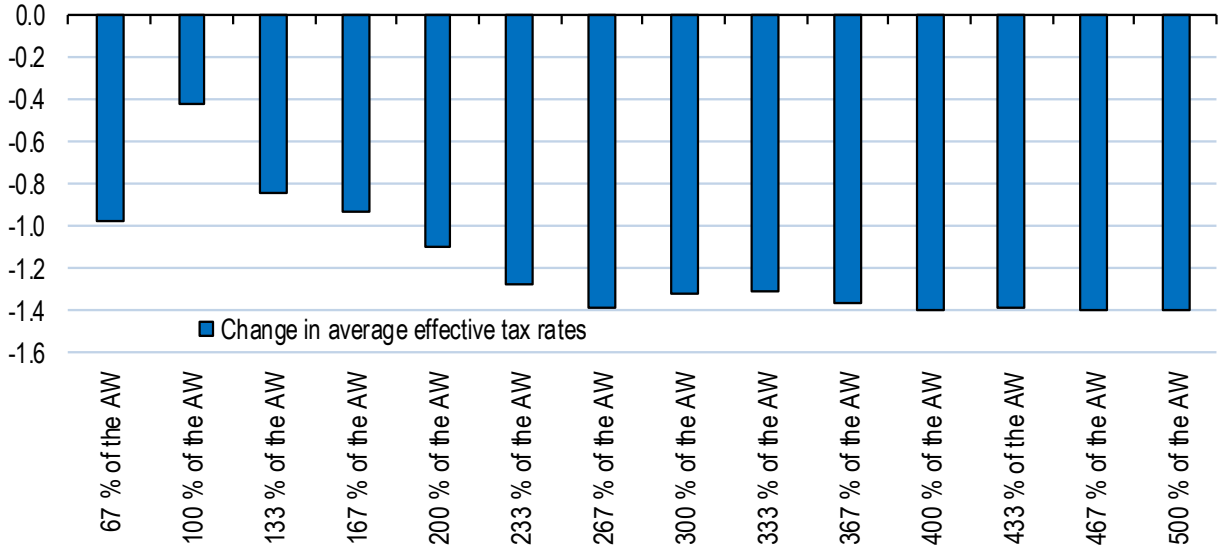

Note: Singles without children. The personal average tax rate is defined as income tax plus employee social security contributions as a percentage of gross wage earnings. Piecewise tax progressivity is calculated as (AETR X2\% AW - AETR X1\%AW) / (X2\%AW-X1\%AW) where AETR X1\%AW and AETR X2\%AW are the average effective tax rates corresponding to two different income levels $\mathrm{X} 1$ and $\mathrm{X} 2$, respectively. The indicator measures how the average PIT rate increases per percentage point increase in income, measured as a multiple of the AW, over the X2\% AW - X $1 \% \mathrm{AW}$ income range. The overall tax progressivity is calculated as $\mathrm{X} 1=50 \%$ AW while X2=500\% AW.

Source: CTPA Taxing Wages database, Changes in structural labour income tax progressivity. 


\section{A focus on top personal income tax rates and the taxation of capital income $e^{51}$}

Looking at PIT progressivity with an explicit focus on the top of the distribution and of capital income suggests that policy changes in this area can also significantly affect income redistribution (Table 5). Taken at face value, the results would indicate that a decline in the top statutory PIT rate by 10 percentage points would be associated with a decline in income redistribution by around 6\%, which holds when controlling for the taxation of middle and bottom incomes (columns $1 \& 2$ ). A cut by 10 percentage point of top statutory PIT rates is not uncommon from an historical perspective. A number of studies have documented steep declines in top income taxation over the past decades, as for instance the OECD-wide average top statutory rate went from 50.6\% in 1990 to $41.4 \%$ in 2008. The trend towards declining top PIT rates has reversed slightly in recent years covered by the current estimates, with the average top PIT rate in the OECD reaching $43.3 \%$ in 2016.

Statutory rates can differ and in particular be higher than effective tax rates actually faced by high-income households because of tax credits and deductions. When the top statutory rate is replaced by the top marginal rate on personal income, the estimated coefficient remains positive but is not statistically significant (column 3). However, a more comprehensive measure of top income taxation, the top marginal rate on personal income and employees' social security contributions, is found to significantly affect redistribution, with a semi-elasticity close to 0.4 (columns $4 \& 5$ ) - implying that a cut by 10 percentage points in top PIT would reduce redistribution by $4 \%$. This is equivalent to a cut by one standard deviation of the current OECD distribution of top PIT, to the cut observed in Latvia between 2010 and 2015 (top PIT went from 29\% to 19\%) and close to that observed in Germany between 2003 and 2006 (top PIT went from 64\% to 56\%); it is equivalent to the 2015 difference in top PIT between Finland (57\%) and the United Kingdom (47\%) or Denmark (56\%) and Spain (45\%).

The taxation of capital income at the individual level is also found to affect redistribution, consistent with the fact that the share of capital relative to labour income increases across the distribution and is particularly high at the very top. Taxation of capital income at the individual level is measured by the net personal tax rate on dividend income: this is an effective tax rate as it is defined as the net top statutory rate to be paid at the shareholder level, taking account of all types of reliefs and gross-up provisions at the shareholder level. The estimated semi-elasticity of 0.3 (columns 6 \&7) implies that a decline in net dividend income taxation by 1 standard deviation (of the current OECD distribution), which is equivalent to around 11 percentage points, would be associated with a decline in redistribution by around $3.5 \%$. This is close to the cut observed in Hungary between 2008 and 2009 (net dividend income taxation went from 35\% to 25\%) and to the 2015 difference in net dividend income taxation between the Canada (34\%) and Spain (23\%).

Studies on capital taxation show that during the 1980s and 1990s reforms in this area have contributed to making OECD tax systems less progressive as for instance some countries introduced dual income tax systems which tax personal capital income at flat

${ }^{51}$ It is important to remind that the data sources used in this paper are likely to underestimate top incomes as is always the case with household surveys. This implies some caution in interpreting the results. The direction of any associated bias is not straightforward to infer because changes in top tax rates imply ambiguous effects on top incomes due to the likely interplay between direct and behavioural effects. 
and lower rates compared to labour income. The more recent data used in the estimates suggest a more nuanced and heterogeneous picture whereby since 2000 some countries such as Belgium and Italy have been experiencing increases and others such as Hungary and Turkey decreases in net dividend taxation. Going further on capital income taxation, the estimates (column $8 \& 9$ ) suggest that income redistribution increases with the share of the overall tax rate on dividend income which is collected through the use of PIT, with an estimated semi-elasticity of 0.2 .

One cautious policy conclusion is that OECD countries willing to increase income redistribution have room to raise the progressivity of PIT, including by stepping-up the taxation of top incomes and reforming personal capital income taxation to make it more progressive. ${ }^{52}$ In this respect, countries do not necessarily need to tax capital more (e.g. to raise statutory rates), and there are strong arguments for broadening the base of capital taxation by removing tax expenditures for capital that have non-distributional policy rationales (such as the desire to increase levels of home ownership in the case of mortgage interest deductibility and the objective of increasing national savings for retirement in the case of the deductibility of pension contributions).

Average findings cannot apply across the board and ultimately policy reforms in this area will depend on country-specific challenges, context, and social preferences; not least taking into account efficiency alongside equity considerations. In any case, changes in the progressivity of PIT through stepping-up the taxation of most affluent individuals must be seen in the broader context of the whole tax system which implies that reforms in this area should: i) consider the coherence and joint effect of capital income and wealth taxation along their impact on income and wealth inequality ${ }^{53}$, ii) be accompanied by efforts to address tax planning and avoidance, and iii) bear in mind the international dimension, which calls for improved international tax cooperation, coordination and exchange of information.

52 Previous OECD work (Brys et al., 2016) call for progressive rates to be applied to personal capital income: in this respect, countries are encouraged to consider introducing "dual progressive income tax" systems which would tax capital income under a separate rate schedule at progressive rates. The rate schedule could exempt or tax at low rates total household capital income below a minimum threshold. This could also encourage taxpayers at the bottom of the income and wealth distribution to save more, which could ultimately contribute to reducing wealth inequality.

${ }^{53}$ See OECD (2018a) for a recent comprehensive report on the taxation of wealth. 
Table 5. Taxes and redistribution: a focus on top tax rates and on the taxation of capital income

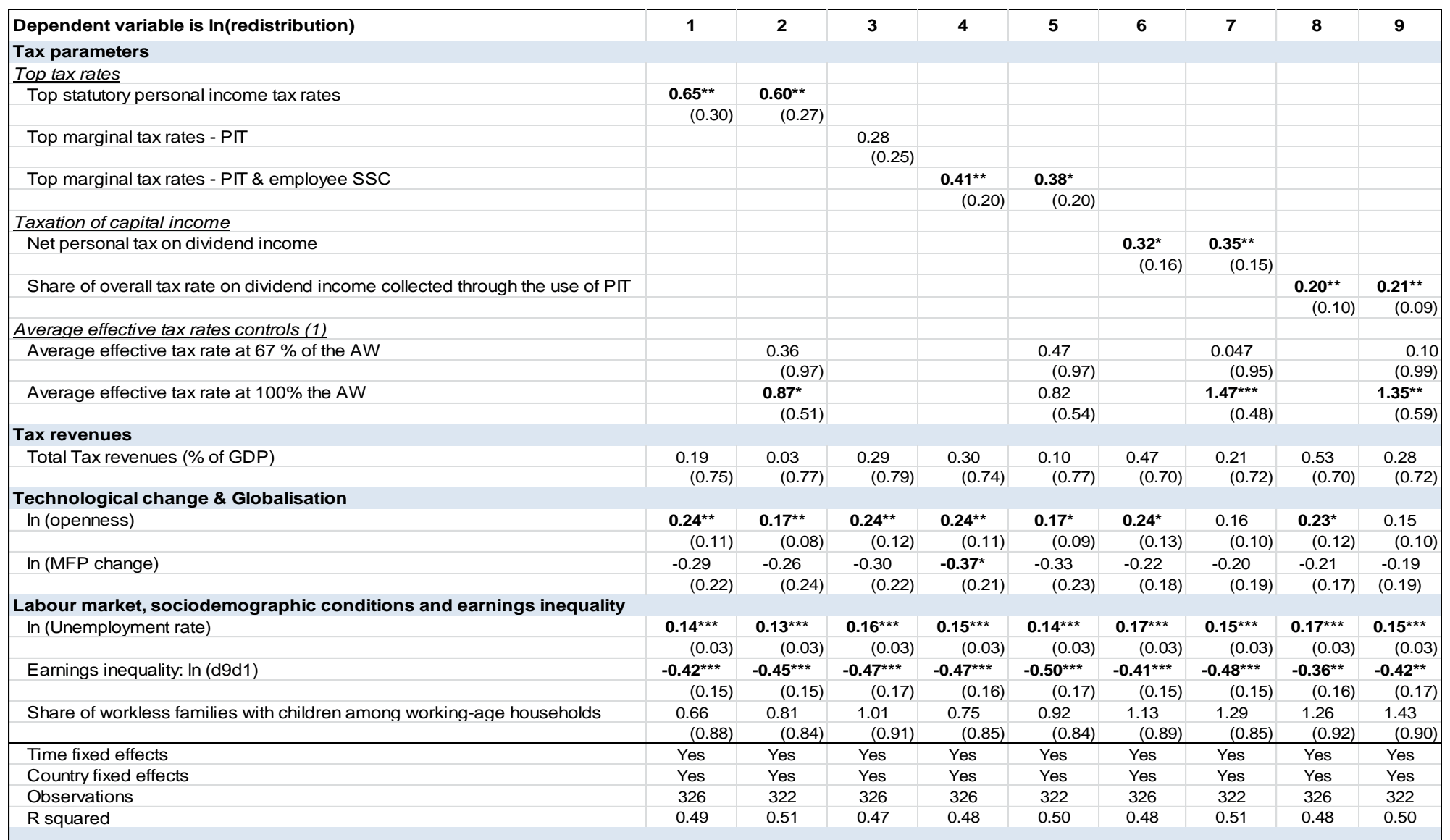

Note: Dependent variable is the natural logarithm of redistribution. Standard errors are clustered at the country level. R squared does not incorporate the effect of country fixed effects. (1) Data refer to single taxpayers without children

Significance levels: * $\mathrm{p}<.1 ; * * \mathrm{p}<.05 ; * * * \mathrm{p}<.0$

Bold highlights significant coefficients 


\section{The tax structure}

Uncovering the effect of the tax structure on income redistribution is relevant insofar as empirical evidence suggests that the tax structure has a strong effect on efficiency and output growth ${ }^{54}$ while less is known about its effect on inequality reduction. ${ }^{55}$ Such analysis is presented in Table 6 but should be taken with caution because, as stressed already, the measure of income redistribution in this as in other comparable papers can only include the effect of personal income taxes and employees' SSC, not of the overall tax system. As a result, the estimates can be interpreted as indirect effects from tax shifts. The results strongly suggest that tax systems that are skewed towards direct taxes, and in particular PIT $^{56}$, are more effective at mitigating inequalities (columns $1 \& 2$ ). This finding reflects the fact that the progressivity of the overall tax system is largely driven by $\mathrm{PIT}^{57}$, because as currently designed in the vast majority of OECD countries, other tax instruments are either not progressive and/or of low size so that their redistributive effect is small.

Taken at face value, the estimates imply that a tax shift towards PIT of 1 percentage point of tax revenue would imply an increase in redistribution by almost $1 \%$. A 1 percentage point change in tax revenue share from PIT is a relatively modest change from a crosscountry perspective, as the current standard deviation across OECD countries is equal to $10 \%$, with countries like Denmark raising more than half of tax revenue from PIT and countries like the Czech Republic raising five times less than that. ${ }^{58}$

\footnotetext{
${ }^{54}$ Akgun et al (2017), Arnold et al (2011).

55 Akgun et al (2017) provide an empirical analysis of the effects of the tax mix on growth and inequality in disposable income. Brys et al (2016) provide a comprehensive qualitative overview of tax design for inclusive growth. These studies alongside the current one on inequality reduction and income redistribution offer complementary perspectives on equity considerations in tax design.

56 The effect of tax revenue from corporate taxes is not significant, neither in isolation nor in addition to that of tax revenue from PIT and employees' SSC which is why it is not reported. The results from column $1 \& 2$ are not affected by controlling for tax revenue from corporate taxes.

${ }^{57}$ Brys et al (2016).

58 The effect of the corporate income tax-to-GDP ratio is not statistically significant, which is not surprising in view of the measured redistribution. The inclusion of the variable has no effect on other relevant parameters which is why it is not considered in Table 6.
} 
Table 6. The tax structure and income redistribution

\begin{tabular}{|c|c|c|c|c|c|c|}
\hline Dependent variable is $\ln$ (redistribution) & 1 & 2 & 3 & 4 & 5 & 6 \\
\hline \multicolumn{7}{|l|}{ Tax structure (\% of Total Tax revenue) } \\
\hline \multirow[t]{2}{*}{ Tax revenue share from PIT and employees' SSC } & $0.87^{\star \star}$ & & & & & \\
\hline & $(0.32)$ & & & & & \\
\hline \multirow[t]{2}{*}{ From PIT } & & $0.97^{\star \star}$ & & & & \\
\hline & & $(0.43)$ & & & & \\
\hline \multirow[t]{2}{*}{ From employees' SSC } & & 0.54 & & & & \\
\hline & & $(0.54)$ & & & & \\
\hline \multirow[t]{2}{*}{ Tax revenue share from goods and services } & & & $-1.53^{\star \star}$ & $-1.50^{\star \star}$ & & \\
\hline & & & $(0.65)$ & $(0.57)$ & & \\
\hline \multirow[t]{2}{*}{ From production, sale transfer } & & & & & $-1.21^{\star \star}$ & $-1.21^{\star \star}$ \\
\hline & & & & & $(0.54)$ & $(0.54)$ \\
\hline \multirow[t]{2}{*}{ From use of goods or permission to use goods } & & & & & $-5.18^{\star \star}$ & $-5.04^{\star \star}$ \\
\hline & & & & & (2.48) & (2.34) \\
\hline \multirow{2}{*}{ Tax revenue share from property } & & & 0.88 & & & 0.36 \\
\hline & & & $(1.26)$ & & & $(1.08)$ \\
\hline \multirow[t]{2}{*}{ From Recurrent taxes on immovable property } & & & & 1.55 & & \\
\hline & & & & $(2.08)$ & & \\
\hline \multirow[t]{2}{*}{ From Recurrent taxes on net wealth } & & & & 4.04 & & \\
\hline & & & & $(4.43)$ & & \\
\hline \multirow[t]{2}{*}{ From Estate, inheritance and gift taxes } & & & & 1.54 & & \\
\hline & & & & $(5.48)$ & & \\
\hline \multirow[t]{2}{*}{ From taxes on financial and capital transactions } & & & & -1.26 & & \\
\hline & & & & $(2.21)$ & & \\
\hline \multirow[t]{2}{*}{ From Non-recurrent taxes on property } & & & & 2.74 & & \\
\hline & & & & (3.79) & & \\
\hline \multicolumn{7}{|l|}{ Tax revenues (\% of GDP) } \\
\hline \multirow{2}{*}{ Total Tax revenues } & $1.41^{\star \star *}$ & $1.35^{\star \star \star}$ & 0.29 & 0.45 & 0.36 & 0.36 \\
\hline & $(0.46)$ & $(0.41)$ & $(0.62)$ & $(0.74)$ & $(0.46)$ & $(0.46)$ \\
\hline \multicolumn{7}{|l|}{ Technological change \& Globalisation } \\
\hline \multirow[t]{2}{*}{ In (openness) } & 0.06 & 0.06 & $0.21^{*}$ & $0.18^{\star \star}$ & $0.17^{\star \star}$ & $0.18^{\star \star}$ \\
\hline & $(0.07)$ & $(0.07)$ & $(0.11)$ & $(0.09)$ & $(0.08)$ & $(0.08)$ \\
\hline \multirow{2}{*}{ In (MFP change) } & $-0.33^{\star}$ & $-0.31^{\star}$ & $-0.53^{\star \star}$ & $-0.49^{\star \star}$ & $-0.48^{\star \star}$ & $-0.48^{\star \star}$ \\
\hline & $(0.18)$ & $(0.17)$ & $(0.22)$ & $(0.22)$ & $(0.20)$ & $(0.20)$ \\
\hline \multicolumn{7}{|l|}{ Labour market, sociodemographic conditions and earnings inequality } \\
\hline \multirow[t]{2}{*}{ In (Unemployment rate) } & $0.13^{\star \star \star}$ & $0.13^{\star \star \star}$ & $0.14^{\star \star \star}$ & $0.12^{\star \star \star}$ & $0.14^{\star \star \star}$ & $0.14^{\star \star \star}$ \\
\hline & $(0.03)$ & $(0.03)$ & $(0.02)$ & $(0.04)$ & $(0.02)$ & $(0.02)$ \\
\hline \multirow[t]{2}{*}{ Earnings inequality: $\ln (\mathrm{d} 9 \mathrm{~d} 1$ ) } & $-0.35^{\star \star}$ & $-0.35^{\star \star}$ & $-0.49^{\star \star \star}$ & $-0.47^{\star \star \star}$ & $-0.53^{\star \star \star}$ & $-0.52^{\star \star \star}$ \\
\hline & $(0.15)$ & $(0.15)$ & $(0.15)$ & $(0.15)$ & $(0.16)$ & $(0.16)$ \\
\hline \multirow[t]{2}{*}{ Share of workless families with children among working-age households } & 1.20 & 1.17 & 0.80 & 0.63 & 1.08 & 1.06 \\
\hline & $(0.89)$ & $(0.90)$ & $(0.97)$ & $(0.94)$ & $(0.99)$ & $(0.99)$ \\
\hline Time fixed effects & Yes & Yes & Yes & Yes & Yes & Yes \\
\hline Country fixed effects & Yes & Yes & Yes & Yes & Yes & Yes \\
\hline Observations & 344 & 344 & 357 & 357 & 357 & 357 \\
\hline R squared & 0.53 & 0.53 & 0.54 & 0.55 & 0.55 & 0.55 \\
\hline
\end{tabular}

Note: Dependent variable is the natural logarithm of redistribution. Standard errors are clustered at the country level. R squared does not incorporate the effect of country fixed effects.

Significance levels: * $\mathrm{p}<.1 ; * * \mathrm{p}<.05 ; * * * \mathrm{p}<.01$

Bold highlights significant coefficients

The effect of taxes on goods and services is estimated in conjunction with that of property taxes because tax studies have suggested that these two tax bases are the least distortive for economic growth and therefore that shifting from direct to indirect and property taxes would meet the efficiency objective.$^{59}$ The question is whether such shift would meet the equity or redistribution objective and results can be summarised as follows:

- The estimates fail to identify a statistically significant effect from property taxes, neither overall (column 3), nor when decomposed along the various different types of property taxes (column 4). This could reflect the generally limited

${ }^{59}$ Still, the results on taxes on goods and services and property taxes hold in isolation from each other. 
variation over time and the fact that property taxes are not fully captured in the left-hand side redistribution measure. One interpretation could still be that there is room to improve the design of property taxes so as to make them more effective at reducing income inequality. ${ }^{60}$ Because property taxes are considered as less distortive then PIT, stepping-up their weight and reviewing their design could be one strategy to boost income redistribution without affecting efficiency.

- By contrast, the estimates identify a highly statistically significant effect from taxes on goods and services which are found to reduce income redistribution (columns 3 \& 4). This finding does not have a clear direct interpretation because indirect taxes are not captured in the left-hand side redistribution measure. However, it is consistent with, and needs to be interpreted in light of, the findings from columns 1 and 2: because in the majority of OECD countries PIT and indirect taxes are the most important sources of tax revenue, tax systems skewed towards indirect taxes feature low overall progressivity hence low redistribution compared with tax systems skewed towards PIT. ${ }^{61}$ The regressive effect from direct taxes comes from both taxes from production, sale and transfer (e.g. VAT, sale and excise taxes) and taxes from the use of goods or permission to use goods and perform activities (e.g. taxes on vehicle licences and environmental taxes) (columns $5 \& 6$ ). The latter estimate is of larger magnitude compared to the former but the size of the underlying instrument is also much smaller: taxes on use of goods represent on average less than $2 \%$ of overall tax revenue with 0.8 standard deviation while taxes on production, sale and transfer represent around $30 \%$ of overall tax revenue with a tenfold standard deviation across OECD countries. Overall, these results are likely to point to the (average) effects from tax shift reforms taking place within countries over the period under consideration: for example, taken at face value, the estimates would imply that an increase by 5 percentage points in the share of tax revenue raised from taxes on goods and services, as observed in Israel between 2007 and 2014 in concomitance with an almost equivalent decline in the share of tax revenue raised from PIT, would have reduced income redistribution by around 5.5\%. This would suggest that over the last decades, tax reforms motivated by efficiency or environmentalsustainability objectives, hence involving a shift from PIT towards indirect taxes, may have contributed to reduce income redistribution across OECD countries.

\subsubsection{Transfers as instruments of redistribution}

This section investigates the effect of selected parameters of the transfer system that are likely to affect income redistribution. The focus is largely on cash transfers to workingage population to be consistent with what is being measured as redistribution. Relative to the tax analysis, the transfer analysis is empirically more difficult because granular data on transfer instruments are only available for a very recent period and in number of cases for a subset of OECD countries, which further reduces the sample size and challenges the econometric identification. The empirical model builds on the baseline and systematically controls for total social spending (as a share of GDP) so as to consider spending-neutral

\footnotetext{
${ }^{60}$ This is in line with results in $\operatorname{IMF}(2017,2018)$.

${ }^{61}$ This is tentatively confirmed by the high and statistically negative correlation (of - 0.4) between the tax revenue share from PIT and that from taxes on goods and services.
} 
policy scenarios. Regressions where both total social spending and social spending on cash support to the working-age population are reported in the Appendix.

\section{Unemployment-related transfers and activation}

The descriptive analysis in Causa and Hermansen (2017) shows that insurance transfers -in particular unemployment-related transfers -- have been major drivers of the decline in income redistribution across OECD countries. It also shows that workless households at the bottom of the distribution have indeed experienced significant declines in transfer support. Moving from descriptive to regression analysis tends to confirm these findings. This broad conclusion emerges from an investigation of the effects on redistribution of net unemployment benefit replacement for different socioeconomic groups (Table 7):

- Estimates are significant for overall (i.e. over 5 years) net replacement rates, but only for jobseekers with previous earnings below and at the AW (columns 1-3);

- Estimates are never significant for initial replacement rates, that is, benefits paid to jobseekers at the beginning of the unemployment spell (columns 4-5);

- Estimates are highly significant for long-term replacement rates, that is, benefits and social assistance paid to the long-term unemployed (i.e. after 5 years) (columns 6-7). 
Table 7. Transfers and redistribution: A focus on unemployment-related transfers

\begin{tabular}{|c|c|c|c|c|c|c|c|c|c|c|c|c|c|c|}
\hline Dependent variable is $\ln$ (redistribution) & 1 & 2 & 3 & 4 & 5 & 6 & 7 & 8 & 9 & 10 & 11 & 12 & 13 & 14 \\
\hline \multirow{2}{*}{\multicolumn{15}{|c|}{\begin{tabular}{|l|} 
Transfer parameters \\
Net unemployment benefit replacement rate (1)
\end{tabular}}} \\
\hline & & & & & & & & & & & & & & \\
\hline \multirow[t]{2}{*}{ Over 5 years - at $100 \%$ of the $\mathrm{AW}$, married couple } & $0.72^{\star}$ & & & & & & & 0.26 & & & $0.73^{\star \star \star}$ & & & \\
\hline & $(0.37)$ & & & & & & & $(0.23)$ & & & (0.19) & & & \\
\hline Over 5 years - at $150 \%$ of the $\mathrm{AW}$, married couple & & $\begin{array}{l}0.65 \\
(0.50)\end{array}$ & & & & & & & & & & & & \\
\hline \multirow{2}{*}{ Over 5 years - at $67 \%$ of the $A W$, married couple } & & & $0.55^{\star \star}$ & & & & & & 0.25 & & & $0.56^{\star \star *}$ & & \\
\hline & & & $(0.25)$ & & & & & & $(0.17)$ & & & $(0.11)$ & & \\
\hline Initial - at $100 \%$ of the AW, married couple & & & & $\begin{array}{l}0.37 \\
(0.24)\end{array}$ & & & & & & & & & & \\
\hline \multirow[t]{2}{*}{ Initial - at $67 \%$ of the $\mathrm{AW}$, married couple } & & & & & 0.11 & & & & & & & & & \\
\hline & & & & & $(0.16)$ & & & & & & & & & \\
\hline \multirow[t]{2}{*}{ Long-term- at $100 \%$ of the $\mathrm{AW}$, married couple } & & & & & & $0.59^{*}$ & & & & & & & & \\
\hline & & & & & & (0.32) & & & & & & & & \\
\hline \multirow[t]{2}{*}{ Long-term-at $67 \%$ of the $A W$, married couple } & & & & & & & $\begin{aligned} \mathbf{0 . 4 8}^{*} \\
(0.24)\end{aligned}$ & & & $\begin{array}{l}0.19 \\
(0.16)\end{array}$ & & & $0.38^{* \star \star}$ & $\begin{aligned} \mathbf{0 . 2 9}^{\star \star} & (0.13)\end{aligned}$ \\
\hline & & & & & & & & & & & & & $(0.13)$ & \\
\hline \multirow[t]{2}{*}{ Unemployment insurance coverage (2) } & & & & & & & & & & & $0.65^{\star}$ & $0.69 * \star$ & $0.63^{*}$ & $0.91^{\star \star \star}$ \\
\hline & & & & & & & & & & & $(0.32)$ & $(0.31)$ & $(0.36)$ & $(0.31)$ \\
\hline \multicolumn{15}{|l|}{ Social spending (in\% of GDP) } \\
\hline Spending on active labour market policies (3) & & & & & & & & $-11.99^{*}$ & $-12.18^{\star \star *}$ & $-12.59^{\star \star}$ & & & & $-15.92^{\star \star \star}$ \\
\hline \multirow[t]{2}{*}{ Total Social spending } & 0.09 & 0.16 & 0.08 & 0.24 & 0.33 & 0.16 & 0.17 & $1.26^{*}$ & $1.20^{*}$ & $1.29^{*}$ & 1.01 & 0.82 & 1.02 & 0.86 \\
\hline & $(1.03)$ & $(1.07)$ & $(1.02)$ & $(1.02)$ & $(1.04)$ & $(1.03)$ & $(0.99)$ & $(0.70)$ & $(0.69)$ & $(0.72)$ & $(1.23)$ & (1.23) & $(1.27)$ & $(0.96)$ \\
\hline \multirow{2}{*}{$\begin{array}{l}\text { Technological change \& Globalisation } \\
\text { In (openness) }\end{array}$} & & & & & & & & & & & & & & \\
\hline & $0.20^{\star \star \star}$ & $0.22^{\star \star}$ & $0.19^{\star \star}$ & $0.22^{\star \star}$ & $0.24^{\star \star}$ & $0.20^{\star \star \star}$ & $0.19^{\star \star \star}$ & $0.14^{\star \star}$ & $0.13^{\star \star}$ & $0.14^{\star \star \star}$ & $0.16^{\star}$ & 0.13 & $0.16^{*}$ & $0.13^{*}$ \\
\hline \multirow{3}{*}{ In (MFP change) } & $(0.07)$ & $(0.08)$ & $(0.07)$ & $(0.08)$ & $(0.09)$ & $(0.07)$ & $(0.07)$ & $(0.05)$ & $(0.05)$ & $(0.05)$ & $(0.09)$ & $(0.09)$ & $(0.09)$ & $(0.07)$ \\
\hline & -0.14 & -0.14 & -0.13 & -0.12 & -0.10 & -0.11 & -0.09 & -0.10 & -0.09 & -0.10 & -0.32 & -0.32 & -0.32 & -0.08 \\
\hline & $(0.22)$ & $(0.21)$ & $(0.22)$ & $(0.19)$ & $(0.20)$ & $(0.22)$ & $(0.21)$ & $(0.25)$ & $(0.25)$ & $(0.25)$ & $(0.32)$ & (0.33) & (0.32) & $(0.28)$ \\
\hline \multirow{2}{*}{$\begin{array}{l}\text { Labour market, sociodemographic conditions and earnings inequalit) } \\
\text { In (Unemployment rate) }\end{array}$} & & & & & & & & & & & & & & \\
\hline & $\begin{array}{l}0.17^{\star \star \star} \\
(0.04)\end{array}$ & $\begin{array}{l}0.17^{\star \star \star} \\
(0.04)\end{array}$ & $\begin{array}{l}0.17^{\star \star *} \\
(0.04)\end{array}$ & $\begin{array}{l}0.18^{\star \star *} \\
(0.04)\end{array}$ & $\begin{array}{r}0.17^{\star \star \star} \\
(0.04)\end{array}$ & $\begin{array}{l}0.17^{\star \star \star} \\
(0.04)\end{array}$ & $\begin{array}{l}\mathbf{0 . 1 7 * \star} \\
(0.04)\end{array}$ & $\begin{array}{r}0.14^{\star \star \star} \\
(0.03)\end{array}$ & $\begin{array}{r}0.14^{\star \star \star} \\
(0.03)\end{array}$ & $\begin{array}{l}0.14^{\star \star \star} \\
(0.03)\end{array}$ & $\begin{array}{l}0.09 \\
(0.07)\end{array}$ & $\begin{array}{l}0.10 \\
(0.07)\end{array}$ & $\begin{array}{l}0.10 \\
(0.07)\end{array}$ & $\begin{array}{r}0.18^{\star \star \star} \\
(0.05)\end{array}$ \\
\hline \multirow[t]{2}{*}{ Earnings inequality: In (d9d1) } & $-0.54^{\star \star \star}$ & $-0.54^{\star \star \star}$ & $\begin{array}{l}-0.53^{\star \star \star} \\
(0.18)\end{array}$ & $-0.56^{\star \star \star \star}$ & $-0.52^{\star \star \star}$ & $-0.53^{* \star \star}$ & $-0.54^{\star \star \star}$ & $-0.47^{\star \star}$ & $-0.47^{\star \star}$ & $-0.48^{* \star}$ & $-0.81^{\star \star \star}$ & $-0.79^{\star \star \star}$ & $-0.79^{* *}$ & $-0.64^{\star \star}$ \\
\hline & $(0.18)$ & $(0.17)$ & $(0.18)$ & $(0.18)$ & $(0.17)$ & $(0.17)$ & $(0.17)$ & $(0.20)$ & $(0.21)$ & $(0.20)$ & $(0.29)$ & $(0.29)$ & $(0.30)$ & $(0.29)$ \\
\hline Share of workless families with children among working-age households & $\begin{array}{l}1.19 \\
(1.31)\end{array}$ & ${ }_{(1.34)}^{1.32}$ & $\begin{array}{l}1.15 \\
(1.29)\end{array}$ & 1.84 & 1.77 & 1.14 & 1.07 & 1.25 & 1.15 & 1.21 & 1.79 & $1.84^{\star}$ & 1.83 & 1.44 \\
\hline & (1.31) & $(1.34)$ & (1.29) & $\frac{(1.22)}{y \Gamma c}$ & $\frac{(1.23)}{v(c) ~}$ & $(1.32)$ & (1.35) & $(1.27)$ & (1.26) & 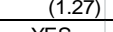 & $\frac{(1.08)}{V(x)}$ & $(1.08)$ & (1.11) & 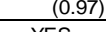 \\
\hline Time fixed effects & YES & YES & YES & YES & YES & YES & YES & YES & YES & YES & YES & YES & YES & YES \\
\hline Country fixed effects & YES & YES & YES & YES & YES & YES & YES & YES & YES & YES & YES & YES & YES & YES \\
\hline Observations & 304 & 304 & 304 & 304 & 304 & 304 & 304 & 272 & 272 & 272 & 152 & 152 & 152 & 142 \\
\hline R squared & 0.55 & 0.53 & 0.55 & 0.52 & 0.51 & 0.54 & 0.54 & 0.50 & 0.51 & 0.51 & 0.59 & 0.59 & 0.58 & 0.63 \\
\hline
\end{tabular}

Note: Dependent variable is the natural logarithm of redistribution. Standard errors are clustered at the country level. R squared does not incorporate the effect of country fixed effects. (1) Families without children. (2) $\%$ of labour force insured for unemployment risk. (3) Active measures only (categories 10-70)

Significance levels: * p<.1; ** $\mathrm{p}<.05$; **** $\mathrm{p}<.01$

Bold highlights significant coefficients 
The broad result of a significant positive association between the generosity of unemployment-related cash transfer and income redistribution is likely to reflect the effect of policy reforms to boost work incentives among target groups and to shift from passive to active support for the unemployed. Over the last decades many OECD countries have implemented welfare reforms aimed at boosting labour market participation and work incentives, especially for socioeconomic groups with weak labour market attachment. This could explain why the effect is only significant effect below and at the AW. The focus has been on activation and conditionality within the "mutual obligation" framework, which has often implied a tightening of eligibility conditions or a reduction in the duration of benefits and more demanding job search requirements for unemployment benefits claimants. ${ }^{62}$ The finding of non-significant effects from initial replacement rates is likely to reflect that the focus of reforms in this area has been on reducing the duration of benefits or to make them decline over the unemployment spell rather than reducing their initial level. Indeed, in many OECD countries over the period for which such data are available, cuts in replacement rates have been relatively widespread and more pronounced for long-term relative to initial replacement rates (Figure 4). The focus on target populations with longer unemployment spells induces a stronger redistributive impact as these populations are less likely to find a job.

Taken at face value, the estimates would imply that a 10 percentage points cut in the long-term replacement rate for low-income married couples, as observed in Sweden between 2001 and 2007 or in New Zealand between 2005 and 2015, would imply a $4.8 \%$ decline in redistribution. Another quantification is to calculate the effect on income redistribution of a change in one standard deviation of the current OECD distribution: as countries are very heterogeneous in this respect, this change is large, equivalent to 27 percentage points, and would imply a more than $10 \%$ change in redistribution.

${ }^{62}$ See OECD (2018b) for a discussion on active labour market policies and conditionality. 
Figure 4. Net unemployment benefit replacement rates for low-income married couples across OECD countries

A. Initial replacement rates

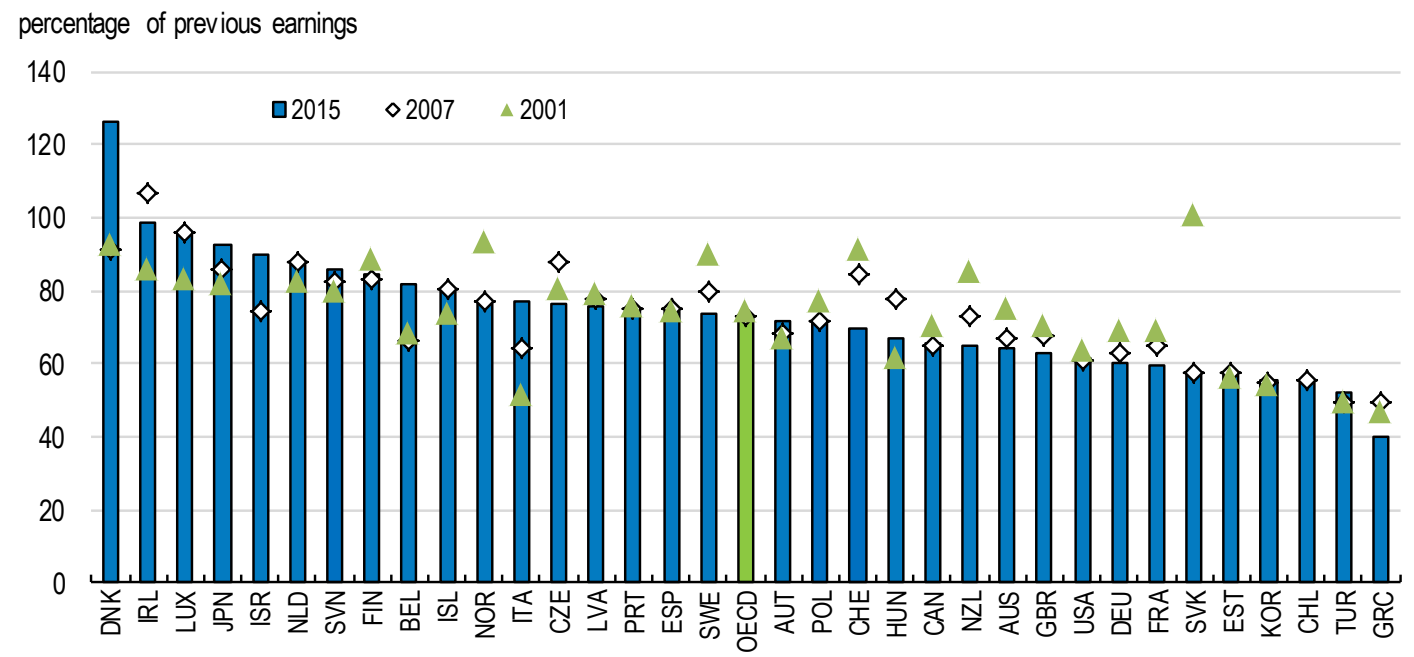

B. Long-term replacement rates (including social assistance)

percentage of previous earnings

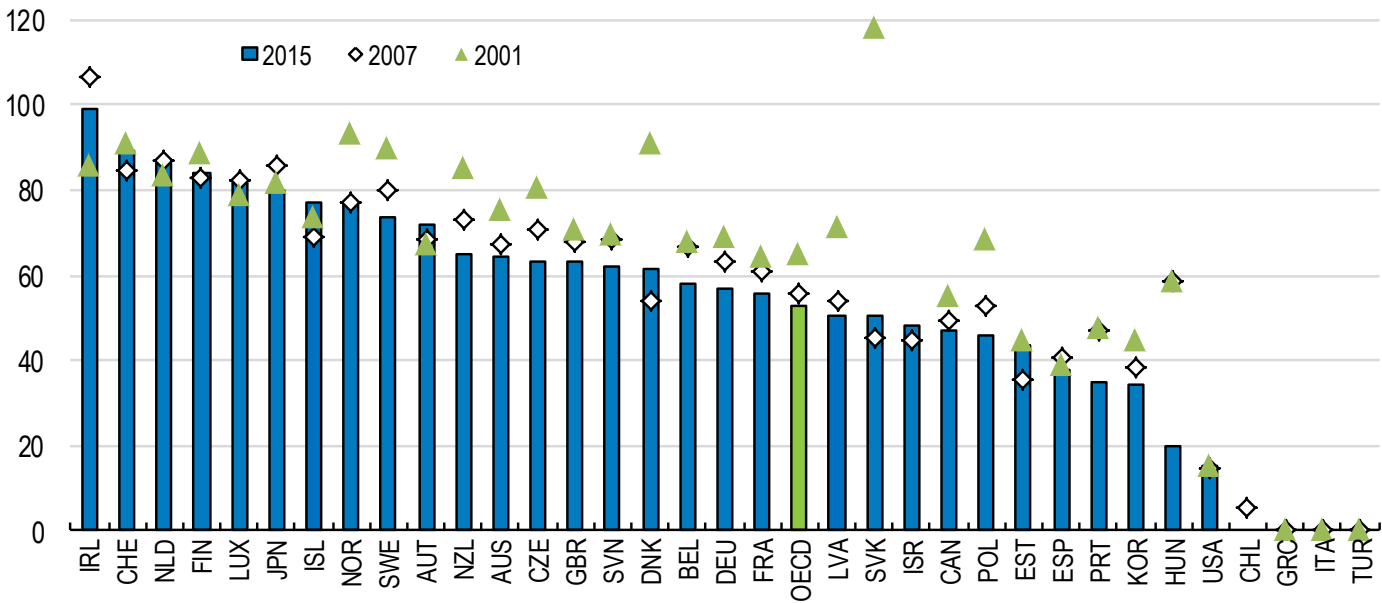

Note: Replacement rate corresponds to $67 \%$ of average wage and to couples without children. For SVN, EST, LVA and TUR the earliest data point corresponds to 2005. For ISR the first data point is from 2008 while for CHL it is 20011, both of which corresponds to 2007 on the chart. Data for MEX is missing. The OECD average is calculated as a simple average.

Source: OECD Benefits and Wages database

To properly identify policy changes associated with shifts from passive to active support for the unemployed, the analysis would need to uncover the proper effect of activation, that is, of changes in eligibility conditions and job search requirements for unemployment benefit claimants. However, policy indicators in this area are still lacking. The only metric that can be used is spending on active labour market policy (ALMP), a rather 
crude proxy for activation and as a very cyclical one. ${ }^{63}$ Still, a tentative investigation of the effect of ALMP spending suggests that, controlling for the level of unemployment benefit replacement rate, increases in spending on activation (relative to GDP) are associated with declines in redistribution (columns 8-10). The effect of unemployment benefit replacement rates becomes statistically insignificant when ALMP spending is entered in the regression. This is potentially driven by multicollinearity between active and passive support variables, as their correlation is close to 0.5 and significant at the 1 percent level. Still, with all due caveats, these findings are in line with the idea that a shift from passive to active support for jobseekers may have contributed to reduce income redistribution among working-age households.

The redistributive effect of unemployment benefit transfers not only depend on their level and duration but also, importantly, on their coverage. For instance, trends towards declining redistribution between the mid-1990s and mid-2000s were linked to declining jobseekers receiving benefits (Immervoll and Richardson, 2011), while more recent data for the period 2007-2014 suggest a steep rise in unemployment benefit receipt at the onset of the crisis, followed by a decline while unemployment remained high (Causa and Hermansen, 2017). The question of unemployment benefit coverage is all the more important in the context of the Future of Work debate as less predictable career patterns, new forms of employment and greater risk of job displacement create challenges for traditional form of social protection. However, moving from descriptive to econometric analysis of the effects of unemployment benefit coverage on income redistribution is hampered by data issues:

- The first-best choice is an OECD source that is only available for the period 20072014, which is too short for the purpose of the current panel estimations. This is the SOCR database which processes and disseminates administrative data on recipients of unemployment benefits in 39 OECD and EU countries. ${ }^{64}$ The data measures observed coverage: i.e. support that is actually received by the unemployed.

- The second-best choice is an external source that is available between the early 1990s and 2011 for 28 OECD countries. This is the Comparative Welfare Entitlements Dataset (CWED), a widely used dataset in political science. ${ }^{65}$ The dataset measures implicit coverage, that is, the share of labour force insured for unemployment risk. This is a de jure concept as opposed to the de facto concept of observed coverage because workers who have built up right to unemployment insurance may or may not claim or qualify for benefits upon unemployment. While these data have been widely used in welfare system analysis, being de jure, they inevitably build on assumptions to compare different legal systems in the area of social protection, for instance with respect to the mix between insurancebased and assistance-based transfers and with respect to the extent of

\footnotetext{
${ }^{63}$ Expressing such spending relative to the number of unemployed is not advisable in the case of the current framework because the specifications already include the unemployment rate. But controlling for the output gap in these specifications does not alter the results.

${ }^{64}$ http://www.oecd.org/social/recipients.htm

${ }^{65}$ Scruggs et al (2017) ; http://cwed2.org/.
} 
conditionality or means-testing. ${ }^{66}$ This data source is exploited in the empirical analysis here, but the results should be taken with care because of abovementioned measurement issues and because of the reduction in the sample size relative to the other sets of regressions.

The results suggest that the coverage of unemployment benefits is one important driver of income redistribution, which holds conditional on benefit generosity as well as on activation (columns 11-14). Going further, the effect of replacement rates becomes much more significant when coverage is controlled for even when activation is included in the regression (columns 13-14). This is intuitive as ultimately the redistributive effect of unemployment-related transfers depends on the extent to which jobseekers can claim them. Taken at face value, the estimates would imply that a decline in the coverage of unemployment benefits by 10 percentage points, as observed in Denmark between 2004 and 2009, would imply more than a $6 \%$ decline in redistribution. One cautious implication is that policy efforts to maintain unemployment benefit coverage at desired levels are likely to also increase income redistribution on top of being beneficial for labour market performance by maintaining effective support for jobseekers in searching for a job that matches their competencies. In the context of current labour market transformations, reforming social protection systems to make them more efficient, resilient and equitable is probably a widely-shared policy priority which countries need to tailor to their context and social preferences.

\section{A focus on public policies for families and children}

Ensuring income adequacy for families and children is one key pillar of redistribution which is deployed through a variety of fiscal instruments such as cash (including unemployment-related, as seen above) and in-kind transfers, but also tax breaks and allowances. ${ }^{67}$ The analysis of the redistributive effect of such instruments is based on a selection of relatively broad indicators of public policies for families and children from on the OECD Family Database. ${ }^{68}$ The results from this analysis need to be taken with caution because the categories of public spending instruments covered by this database do not univocally coincide with the transfer instruments embedded in the dependent variable redistribution measure, that is, cash transfers to the working-age population. ${ }^{69}$ Despite these limitations this analysis delivers some insights, which can be summarised as follows (Table 8):

\footnotetext{
${ }^{66}$ For instance, the coverage is set to $100 \%$ in Australia because there is no unemployment insurance but in principle all unemployed people are eligible for unemployment assistance. That said, according to SOCR data, the share of recipients of unemployment insurance and assistance relative to ILO unemployed is almost $100 \%$ in Australia.

${ }^{67}$ This is a typical case where the separation between taxes and transfers is somewhat artificial yet the allocation to the transfer section here simply results from the fact that in practice the analysis mostly covers the transfer side.

${ }^{68} \mathrm{http}: / / \mathrm{www}$. oecd.org/els/family/database.htm.

${ }^{69}$ For instance spending instruments on family policies may correspond to in-kind transfers and, more generally, to a mix between cash and in-kind transfers.
} 
Table 8. Transfers and redistribution: A focus on public policies for families and children

\begin{tabular}{|c|c|c|c|c|c|c|c|c|c|c|c|c|c|c|}
\hline Dependent variable is In(redistribution) & 1 & 2 & 3 & 4 & 5 & 6 & 7 & 8 & 9 & 10 & 11 & 12 & 13 & 14 \\
\hline \multirow{2}{*}{\multicolumn{15}{|c|}{$\begin{array}{l}\text { Policy indicators } \\
\text { Total public spendina on tamilies as a share of GDP }\end{array}$}} \\
\hline & $2.451\rangle$ & & & & & & & & & & & & & \\
\hline Public spendina on cash benefits tor families as a share of GDP & & 3.88 & & & & & & & & & & & & \\
\hline Public soendino on in-kind benefits for families as a share of GDP & & $(4.55)$ & & & & & & & & & & & & \\
\hline \begin{tabular}{|l|l} 
\\
\end{tabular} & & & 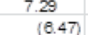 & & & & & & & & & & & \\
\hline Public spendina on taxbreaks br families as a share of GDP & & & & -3.78 & & & & & & & & & & \\
\hline & & & & $0.0 .10)$ & & & & & & & & & & \\
\hline Public spending on early child hood education and care as a share of GDP & & & & & $16.44^{* *}$ & & & & & & & & & \\
\hline & & & & & $(7.55)$ & & & & & & & & & \\
\hline Length of paid matemityleave & & & & & & $\left.0.09^{*}+0.5\right)$ & & & & & & & & \\
\hline Lenath of paid paternityleave & & & & & & & 0.11 & & & & & & & \\
\hline Pmontionaldiforence in nettro & & & & & & & (0.15) & & & & & & & \\
\hline Proportional difference in nettransfers by single and equal-dual eamer couples, household eamings at $133 \%$ of the AW & & & & & & & & $0.0023^{*}$ & & & & & & \\
\hline Proportional difference in nettransfers bysinale and equal-dual eamer couples, household eaminas at $200 \% 0$ fthe AW & & & & & & & & & -0.43 & & & & & \\
\hline & & & & & & & & & $\mid 0.37)$ & & & & & \\
\hline \multicolumn{15}{|l|}{$\begin{array}{l}\text { Labour market situation of women } \\
\text { Gender-gap in the ill-time equivalent employment to population ratio }\end{array}$} \\
\hline Gender-gap in the ill-time equivalente mployment to population ratio & 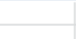 & & & & & & - & & & $-1.72^{2 *}$ & & & & \\
\hline Emplovmentrate of mothers & & & & & & & & & & $(0.74)$ & 0.54: & & & \\
\hline & & & & & & & & & & & $(0.29)$ & & & \\
\hline E mployment rate of partnered mothers & & & & & & & & & & & & $0.63^{* * 1}$ & & \\
\hline Emplovmentrate of sole-parents mothers & & & & & & & & & & & & & -0.12 & \\
\hline & & & & & & & & & & & & & {$[0.17)$} & \\
\hline Women emplovmentrate & & & & & & & & & & & & & & 0.35 \\
\hline \multicolumn{15}{|l|}{ Social spending (in\% of GDP) } \\
\hline Total Social spendina & -0.84 & 1.35 & 0.31 & -0.69 & 1.04 & 1.49 & 1.49 & 0.44 & 0.63 & 0.65 & 1.39 & 1.55 & 1.25 & $1.67^{*}$ \\
\hline & (0.99) & $(0.88)$ & $(1.05)$ & $(102)$ & (088) & $(0.95)$ & $(0.96)$ & $(1.08)$ & $(0.98)$ & $(1.06)]$ & $(0.91]$ & $(0.98)$ & $(0.98)$ & $(0.95)$ \\
\hline \multicolumn{15}{|c|}{ 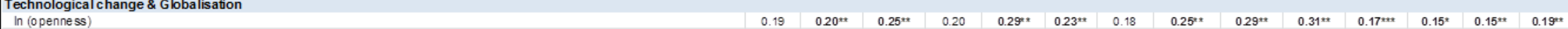 } \\
\hline & $0.19 .14\rangle$ & $(0.09)$ & $(0.11)$ & $0.0 .13)$ & $0.25 .11)$ & 0.091 & 0.10 & $0.20 .10)$ & $20.90 .11\}$ & $(0.12)$ & $(0.06)$ & $\frac{0.15^{*}}{(0.08)}$ & $0.07)$ & $(0.09)$ \\
\hline In (MFP change) & $-0.45^{*}$ & $-0.35^{*}$ & $-0.25^{\circ}$ & $-0.45^{\mathrm{m}}$ & $-0.37^{* x}$ & -0.30 & -0.33 & -0.08 & -0.05 & $-0.32^{2 *}$ & -0.14 & -0.09 & -0.17 & -0.28 \\
\hline \multicolumn{15}{|c|}{ 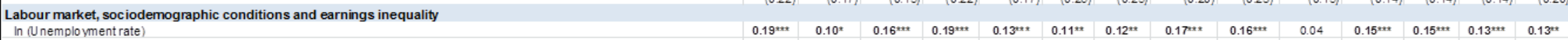 } \\
\hline In (Unemploymentrate) & $0.19^{m+m}$ & $0.10^{*}$ & $0.16^{\mathrm{mex}}$ & $0.19^{\mathrm{m}+\mathrm{x}}$ & $0.13^{m * x}$ & $0.11^{* x}$ & $0.12^{2 *}$ & $0.17+x$ & $0.16^{+m}$ & 0.04 & $0.15^{\mathrm{m}+\mathrm{w}}$ & $0.15^{\text {tat }}$ & $0.13^{+*+1} \mid$ & $0.13^{m+x}$ \\
\hline & (0.04) & $|0.05|]$ & & {$[0.04]$} & 10.04) & (0.05) & $(0.04)$ & {$[0.04)$} & $(0.04)$ & $(0.05)$ & & ${ }^{(0.04)} \mathrm{C}+\mathrm{C}$ & {$[0.04 \mid$} & $(0.05)$ \\
\hline E arnings inequality. In (d9d1) & $-0.67 \pi$ & $-0.50^{\circ+\cdots}$ & $-0.54^{4 * *}$ & $-0.69^{\circ}$ & $-0.54^{+\cdots *}$ & $-0.60^{*}$ & $-0.63^{* *}$ & $-0.52^{2 *}$ & $-0.57 \pm$ & .0.46 & $.0 .44^{* *+1}$ & 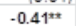 & -0.39"- & 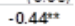 \\
\hline & (0.38) & $(0.17)$ & $(0.17)$ & (0.38) & (0.18) & $10.30)$ & $(0.30)$ & $(0.17)$ & (0.18) & $(0.18)$ & $(0.18)$ & $(0.18)$ & $(0.17)$ & $(0.18)$ \\
\hline Share of workless families with children among working-age house holds & 1.05 & 1.26 & 1.58 & 0.97 & 0.93 & 1.02 & 0.96 & $2.17^{*}$ & 1.7 & 0.67 & 1.88 & 1.84 & 1.62 & 1.25 \\
\hline Time ixed effeds & $\begin{array}{l}\text { Y(1.10) } \\
\text { YES }\end{array}$ & 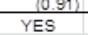 & $\frac{\langle 1.09)_{1}}{Y \text { Y }}$ & $\frac{1(1.09)}{\text { YES }}$ & $\frac{\{1.02\}}{Y E S}$ & $\frac{10.94)}{\text { YES }}$ & $\frac{10.881}{\text { YES }}$ & $\frac{[1,28\}}{Y E S}$ & $\frac{[1.09]}{Y E S}$ & $\frac{(1.06)}{\gamma E S}$ & $\frac{\{1,31\}}{\text { YES }}$ & $\frac{\{1.41\}}{\mathrm{VES}}$ & $\frac{\langle 1.35]}{Y F S}$ & $\frac{(0.821}{Y \text { Y }}$ \\
\hline Countrv fixed effects & YES & YES & YES & YES & YES & YES & YES & YES & YES & YES & YES & YES & YES & YES \\
\hline Observations & 178 & 329 & 280 & 179 & 298 & 320 & 320 & 304 & 304 & 304 & 203 & 254 & 254 & 358 \\
\hline R squared & 0.52 & 0.53 & 0.50 & 0.52 & 0.55 & 0.52 & 0.52 & 0.51 & 0.52 & 0.53 & 0.55 & 0.58 & 0.55 & 0.51 \\
\hline
\end{tabular}

Note: Dependent variable is the natural logarithm of redistribution. Standard errors are clustered at the country level. R squared does not incorporate the effect of country fixed effects.

Significance levels: * $\mathrm{p}<.1 ; * * \mathrm{p}<.05 ; * * * \mathrm{p}<.01$

Bold highlights significant coefficients. 
- Aggregate measures of public spending on families with children have no statistical effect on income redistribution, whether cash or in-kind (columns 1-3); a result which also holds for public spending for tax breaks on families with children, that is, tax exemptions, child tax allowances and child tax credits (column 4). ${ }^{70}$

- By contrast, public spending on childcare and early education is strongly positively associated with income redistribution (column 5). The underlying indicator covers all public spending towards formal day-care services and preprimary education services, in cash or in kind. The interpretation of this finding is thus both direct (i.e. cash transfers mechanically affect disposable income and disproportionately accrue to low-income households) and indirect (i.e. in-kind transfers may affect market incomes, for instance by facilitating the integration of women in the labour market). Public spending on childcare and early education has tended to increase in the vast majority of OECD countries over the period under consideration (Figure 5): the current results suggest that this may have been a counteracting policy force to the decline in income redistribution. Taken at face value, the estimates would imply that an increase spending on childcare and early education by 0.2 percentage points of GDP, as observed in Germany between 2008 and 2013, would imply a $3.3 \%$ increase in redistribution.

- The length of paid maternity leave is positively associated with income redistribution while no such effect is found for paternity leave (columns $6 \&$ 7) The gender difference is not surprising given that in all OECD countries paternity leave is much shorter than maternity leave and that in number of countries it simply does not exist. The interpretation of the result is relatively direct as maternity leave payments are part of cash transfers to working-age households.

- Tax and transfer systems that provide more incentives to share paid work for lowincome households tend to achieve more redistribution (columns 8\&9). The underlying policy indicator measures the difference in net transfers to government between single-earner couples and equal-dual earner couples as a percentage of net transfers to government by single earner couples. This result holds for a level of household earnings of $133 \%$ of the AW (in the case of equal dual earner couples each spouse is assumed to earn $67 \%$ of the AW); the estimate is oppositesigned but statistically insignificant for a level of household earnings of $200 \%$ of the AW (in the case of equal dual earner couples each spouse is assumed to earn $100 \%$ of the AW).

${ }^{70}$ This result holds when tax revenue is also controlled for. 


\section{Figure 5. Public spending on early childhood education and care: developments across} OECD countries

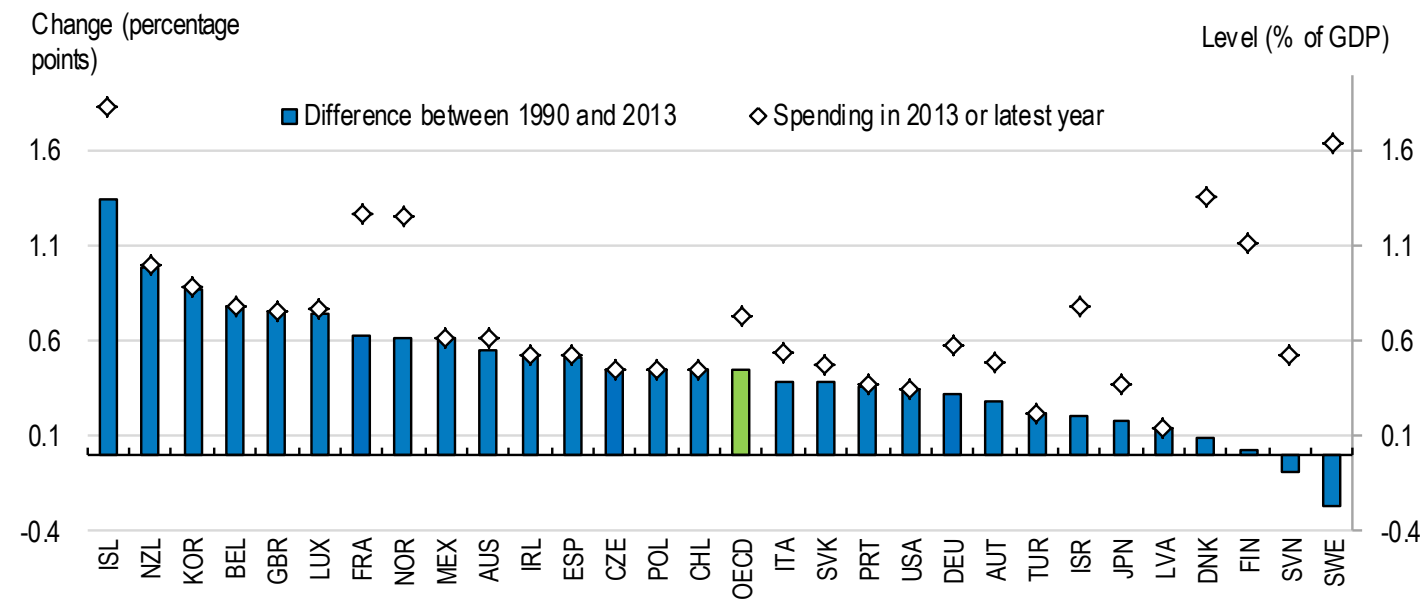

Note: The data refer to spending on early childhood education and care as percentage of GDP. Data is not available for CAN, CHE and GRC. Last available year for POL is from 2012. The earliest data point corresponds to 1991 for USA, to 1995 for ISR, LVA, SVK and to 1996 for GBR and SVN. Data for EST, HUN, NLD is not available for the early 90s. The OECD average is calculated as a simple average.

Source: OECD Family Database

The analysis suggests a positive effect of women and in particular mothers' inclusion in the labour market on income redistribution:

- A higher gender gap in employment is found to negatively affect income redistribution (column 10). ${ }^{71}$

- Maternal employment rates are positively associated with redistribution, yet significantly only for partnered mothers, not for lone mothers (columns 11-13). The level of women employment per se does not have a significant effect on redistribution (column 14).

The family policy results alongside the gender gap results suggest that narrower employment gaps and a more equal distribution of earnings within households, hence tax and transfer policies to facilitate these outcomes, are associated with more effective redistribution. Even though these results could suffer from endogeneity, a cautious interpretation can still point to several mechanisms. Major policy mechanisms relate to family-friendly tax and transfer policies that facilitate women inclusion in the labour market, hence (all else equal) a more equal distribution of market income, and at the same time a more equal distribution of disposable income, which can be the case to the extent that such policies disproportionately affect lower-income households.

71 The gender gap is measured as male less female employment in the full-time equivalent employment-to-population ratio. No significant effect is found in the case of the gender wage gap, even when earnings inequality is not controlled for. 
This is consistent with the finding that redistribution increases with transfers on early education and childcare insofar as those transfers benefit relatively more low-income households. It is also consistent with the finding that it increases with tax and transferrelated incentives to enter into paid work for partners and second earners in the lower part of the earnings distribution but not in the higher part. This difference in the effect of family taxation across the earnings distribution may reflect the interplay between: i) inequality reduction associated with tax and transfer incentives to enter into paid work for partners, the effects of which materialise in the lower part of the distribution where labour supply elasticity is relatively high, and ii) inequality increases potentially associated with shifts from joint to individual family taxation, the effects of which materialise in the upper part of the distribution where tax concentration is relatively high.

The finding that only partnered mothers', not lone mothers' employment, is associated with redistribution is likely to reflect the fact that non-employed lone-parent households (most of the time mothers) are generally net transfer recipients. As a result, their decline may "mechanically" drive redistribution down, a strong enough effect to offset potential opposite-signed mechanisms. ${ }^{72}$ The finding that tax breaks on families do not increase redistribution is likely to reflect the fact that, as currently designed on average across the OECD, such tax breaks may not disproportionately benefit low-income households.

\section{A focus on retirement-related transfers}

Although this paper excludes the elderly from the analysis, the working-age population has also been ageing in the sense that the share of "seniors" (i.e. aged between 55 and 65) in the working-age population has been trending upwards. Causa and Hermansen (2017) show that this compositional change has tended to drive down measured redistribution among the working-age population in a number of a OECD countries, reflecting rising incidence of senior employment -- which more than offset rising incidence of senior households. Rising senior employment likely reflects rising life expectancy in good health, but also well-documented policy reforms to reduce early withdrawal from the labour market and address financial sustainability in pension systems. Moving from descriptive to regression analysis allows for tentatively identifying the role of retirement policy reforms on income redistribution among the working-age population. This is done by relying on newly-developed policy indicators on retirement and pension schemes, from the OECD Pensions at a Glance Database, which however currently cover only 22 OECD countries and is still work-in-progress. ${ }^{73}$ For the purpose of this analysis, the regressions systematically control for demographic conditions i.e. the share of senior (55$65)$ and elderly $(65+)$ in the working-age population as well as social spending on oldage population. The reason is to control for institutional differences governing pension systems in terms of public versus private funding. Main findings can be summarised as follows (Table 9):

\footnotetext{
${ }^{72}$ This is tentatively confirmed by the negative (but non-significant) estimate of the effect of solemothers employment (column 12).

${ }^{73}$ These data are still experimental and will be published in the course of 2018 in Geppert (2018).
} 
Table 9. The effects of old-age pension systems and early retirement incentives on redistribution to the working-age population

\begin{tabular}{|c|c|c|c|c|c|c|c|c|c|c|c|c|c|}
\hline Dependent variable is $\operatorname{In}($ redistribution) & 1 & 2 & 3 & 4 & 5 & 6 & 7 & 8 & 9 & 10 & 11 & 12 & 13 \\
\hline \multicolumn{14}{|l|}{ Old-age pension parameters (1) } \\
\hline \multirow[t]{2}{*}{ Normal retirement age } & -0.01 & & & & & & & & & & & & \\
\hline & $(0.01)$ & & & & & & & & & & & & \\
\hline \multirow[t]{2}{*}{ Normal retirement age, men } & & -0.0082 & & & & & & & & & & & \\
\hline & & $(0.01)$ & & & & & & & & & & & \\
\hline \multirow[t]{2}{*}{ Normal retirement age, women } & & & $-0.01^{\star}$ & & & & & & & & & & \\
\hline & & & $(0.01)$ & & & & & & & & & & \\
\hline \multirow{2}{*}{ Minimum retirement age } & & & & $0.01^{\star \star \star}$ & & & & & & & & & \\
\hline & & & & $(0.00)$ & & & & & & & & & \\
\hline \multirow[t]{2}{*}{ Minimum retirement, men } & & & & & $0.01^{\star \star \star \star}$ & & $0.02^{\star \star \star}$ & $0.02^{\star \star \star}$ & $0.02^{\star \star \star}$ & $0.02^{\star \star \star}$ & $0.02^{* \star \star}$ & & \\
\hline & & & & & $(0.00)$ & & $(0.00)$ & $(0.00)$ & $(0.00)$ & $(0.00)$ & $(0.00)$ & & \\
\hline \multirow{2}{*}{ Minimum retirement, women } & & & & & & $0.01^{\star}$ & & & & & & & \\
\hline & & & & & & $(0.00)$ & & & & & & & \\
\hline \multirow[t]{2}{*}{ Replacement rate from the old-age pension system at age 60 (2) } & & & & & & & $0.08^{*}$ & & & & & & \\
\hline & & & & & & & $(0.04)$ & & & & & & \\
\hline \multirow[t]{2}{*}{ Replacement rate from the old-age pension system at age 65 (2) } & & & & & & & & $0.11^{\star \star}$ & & & & & \\
\hline & & & & & & & & $(0.04)$ & & & & & \\
\hline \multirow[t]{2}{*}{ Replacement rate from the old-age pension system at age 69 (2) } & & & & & & & & & $0.42^{\star \star}$ & & & & \\
\hline & & & & & & & & & $(0.20)$ & & & & \\
\hline \multirow[t]{2}{*}{ Replacement rate from the old-age pension system between ages $60 \& 65$ (average) (2) } & & & & & & & & & & 0.042 & & & \\
\hline & & & & & & & & & & $(0.04)$ & & & \\
\hline \multirow[t]{2}{*}{ Replacement rate from the old-age pension system between ages $65 \& 69$ (average) (2) } & & & & & & & & & & & $0.32^{\star}$ & & \\
\hline & & & & & & & & & & & $(0.16)$ & & \\
\hline \multicolumn{14}{|l|}{ Effective retirement age } \\
\hline \multirow{2}{*}{ Average effective retirement age, men } & & & & & & & & & & & & $-0.02^{*}$ & \\
\hline & & & & & & & & & & & & $(0.01)$ & \\
\hline \multirow[t]{2}{*}{ Average effective retirement age, women } & & & & & & & & & & & & & -0.0002 \\
\hline & & & & & & & & & & & & & $(0.01)$ \\
\hline Social spending (in $\%$ of GDP) & & & & & & & & & & & & & \\
\hline Social spending on old-age population & 1.80 & 1.91 & 1.74 & 1.76 & 1.55 & 1.94 & 1.45 & 1.57 & 1.11 & 1.45 & 1.47 & -2.24 & -2.23 \\
\hline & (2.13) & $(2.20)$ & (2.08) & (1.83) & (1.71) & (1.95) & (1.72) & $(1.70)$ & $(1.90)$ & (1.77) & (1.77) & (2.98) & $(2.94)$ \\
\hline Total Social spending & $2.45^{*}$ & 2.30 & $2.57^{\star}$ & $2.40^{*}$ & $2.48^{*}$ & 2.34 & $2.40^{*}$ & $2.46^{*}$ & $2.33^{\star \star}$ & $2.47^{\star}$ & $2.35^{\star}$ & $2.50^{\star \star}$ & $2.48^{\star *}$ \\
\hline & (1.41) & $(1.42)$ & (1.40) & (1.34) & $(1.33)$ & (1.36) & $(1.27)$ & $(1.30)$ & (1.10) & (1.32) & (1.18) & $(1.16)$ & $(1.18)$ \\
\hline Technological change \& Globalisation & & & & & & & & & & & & & \\
\hline In (openness) & 0.19 & 0.18 & $0.20^{*}$ & 0.19 & 0.19 & 0.18 & 0.17 & 0.18 & 0.21 & 0.18 & 0.18 & $0.21^{\star \star}$ & $0.25^{\star \star}$ \\
\hline & $(0.11)$ & $(0.12)$ & $(0.11)$ & $(0.12)$ & $(0.12)$ & $(0.12)$ & $(0.12)$ & $(0.12)$ & $(0.13)$ & $(0.12)$ & $(0.12)$ & $(0.90)$ & $(0.12)$ \\
\hline In (MFP change) & -0.22 & -0.23 & -0.19 & -0.12 & -0.10 & -0.13 & -0.13 & -0.13 & -0.10 & -0.11 & -0.12 & $-0.39^{*}$ & $-0.43^{*}$ \\
\hline & $(0.13)$ & $(0.14)$ & $(0.12)$ & $(0.14)$ & $(0.14)$ & $(0.14)$ & $(0.13)$ & $(0.13)$ & $(0.12)$ & $(0.14)$ & $(0.13)$ & $(0.20)$ & $(0.23)$ \\
\hline Labour market, sociodemographic conditions and earnings inequality & & & & & & & & & & & & & \\
\hline Share of $55-65$ in working-age population & -0.95 & -0.96 & -0.95 & -1.13 & -1.16 & -1.09 & -0.86 & -1.26 & $-1.63^{\star}$ & -1.07 & -1.49 & 0.10 & 0.13 \\
\hline & $(1.08)$ & $(1.08)$ & $(1.09)$ & $(1.03)$ & (1.02) & $(1.04)$ & $(1.06)$ & (1.01) & (0.92) & $(1.06)$ & $(0.96)$ & (1.10) & (1.16) \\
\hline Old-age dependency ratio & -0.56 & -0.57 & -0.62 & -1.13 & -1.21 & -1.04 & -1.17 & -1.11 & -1.25 & -1.19 & -1.12 & -0.62 & -0.59 \\
\hline & $(0.97)$ & $(1.00)$ & (0.94) & $(0.92)$ & $(0.91)$ & (0.93) & $(0.87)$ & $(0.90)$ & $(0.82)$ & $(0.92)$ & $(0.85)$ & $(0.67)$ & $(0.71)$ \\
\hline In (Unemployment rate) & 0.03 & 0.04 & 0.03 & 0.02 & 0.02 & 0.03 & 0.03 & 0.03 & 0.03 & 0.03 & 0.03 & $0.08^{\star}$ & $0.08^{\star}$ \\
\hline & $(0.04)$ & $(0.04)$ & $(0.04)$ & $(0.04)$ & $(0.04)$ & $(0.04)$ & $(0.04)$ & $(0.04)$ & $(0.04)$ & $(0.04)$ & $(0.04)$ & $(0.05)$ & $(0.05)$ \\
\hline Earnings inequality: $\ln (\mathrm{d} 9 \mathrm{~d} 1)$ & $-0.45^{* *}$ & $-0.43^{* \star}$ & $-0.46^{* \star *}$ & $-0.38^{*}$ & $-0.41^{* *}$ & $-0.36^{\star}$ & $-0.41^{* \star}$ & $-0.42^{* *}$ & $-0.45^{* \star}$ & $-0.41^{* \star}$ & $-0.44^{* \star}$ & $-0.61^{\star \star \star}$ & $-0.59^{* *}$ \\
\hline & $(0.17)$ & $(0.18)$ & $(0.16)$ & $(0.18)$ & $(0.18)$ & (0.18) & $(0.18)$ & (0.19) & (0.19) & $(0.18)$ & $(0.19)$ & $(0.22)$ & $(0.22)$ \\
\hline Share of workless families with children among working-age households & 1.24 & 1.34 & 1.19 & $1.66^{*}$ & $1.65^{*}$ & 1.64 & $1.68^{*}$ & 1.51 & 1.38 & $1.61^{*}$ & 1.40 & 1.16 & 1.47 \\
\hline & $(0.97)$ & $(0.98)$ & $(0.96)$ & $(0.92)$ & $(0.89)$ & $(0.96)$ & $(0.89)$ & $(0.90)$ & $(0.90)$ & $(0.89)$ & $(0.92)$ & $(0.95)$ & $(0.95)$ \\
\hline Time fixed effects & YES & YES & YES & YES & YES & YES & YES & YES & YES & YES & YES & YES & YES \\
\hline Country fixed effects & YES & YES & YES & YES & YES & YES & YES & YES & YES & YES & YES & YES & YES \\
\hline Observations & 233 & 233 & 233 & 229 & 229 & 229 & 229 & 229 & 229 & 229 & 229 & 327 & 327 \\
\hline Rsquared & 0.65 & 0.64 & 0.65 & 0.66 & 0.66 & 0.65 & 0.67 & 0.67 & 0.68 & 0.66 & 0.67 & 0.55 & 0.54 \\
\hline
\end{tabular}

Note: Dependent variable is the natural logarithm of redistribution. Standard errors are clustered at the country level. $\mathrm{R}$ squared does not incorporate the effect of country fixed effects. (1)Legal age conditions for someone who enters the labour market at age 25 and exclude minimum contribution period conditions. The idea is to use legal ages that are referred to in public as the typical retirement ages. (2) Men. Excluding any kind of benefit received from unemployment benefit schemes or disability pension schemes.

Significance levels: $* p<.1 ; * * p<.05 ; * * * p<.01$

Bold highlights significant coefficients. 
- An increase in the normal retirement age, that is, the statutory age at which workers access full old-age pension transfers, is associated with a decline in income redistribution among working-age households (columns 1-3); significantly so in the case of women (column 3 ). This is likely to reflect the relatively fast increase in actual retirement ages for women as a consequence of policies to equalise pension ages between genders (OECD, 2017c).

- An increase in the minimum retirement age, that is, the age at which workers can start to access old-age pension transfers though usually at a reduced rate, is associated with an increase in income redistribution among working-age households (columns 4-6); more significantly so in the case of men (column 5). This result could indicate that reforms in this area may have induced claimants to shift from old-age pensions to alternative social transfers, in particular unemployment and disability-related transfers which can be received before eligibility to an old-age pension is reached (i.e. before the minimum retirement age).

- Controlling for the minimum retirement age, a decline in replacement rates from old-age pension systems available for men $^{74}$ at ages $60^{75}, 65$ to 69 is associated with a decline in income redistribution among working-age households (columns 7-11). This could reflect two effects: 1) a budgetary effect, whereby lower pension replacement rates for seniors in the working-age population mechanically, all-else equal, reduce income redistribution and, 2) a behavioural effect, whereby lower pension replacement today and in the future induce seniors in the working-age population to work longer, which also reduces income redistribution. The order of magnitude of estimated effects is low, which is not surprising as the data largely exclude pensioners: taken at face value, a decline by 5 percentage points of the replacement rate from old-age pension systems available for 65 year-old men, as observed in Italy between 1999 and 2007 , would imply a $0.55 \%$ decline in redistribution among working-age households.

The current analytical framework does not allow for identifying and disentangling the various mechanisms underlying these findings, which would require individual-level data by age category and transfer receipt. That said, one conclusion is that the increase in working lives, partly driven by pension reforms to encourage working longer, may have contributed to the decline in income redistribution among working-age households, though to a limited extent. This is confirmed by the finding of a significant and robust negative association between the average effective retirement age and income redistribution in the case of men (columns 12-13). While this association is not to be interpreted causally due to

\footnotetext{
${ }^{74}$ Estimates for women are usually not significant so not shown for parsimony; they are available upon request.

${ }^{75}$ Earlier ages than 60 are not presented because for many countries associated replacement rates are equal to 0 over the whole period, which greatly reduces degrees of freedom for identification purposes, especially in a fixed-effects estimation setting with limited number of countries.
} 
endogeneity concerns ${ }^{76}$, it does point to a link between retirement decisions and redistribution among the working-age population, confirming descriptive evidence in Causa and Hermansen (2017). At the same time, the finding that increases in the minimum retirement age tended to go in the opposite direction does point to the complexity of the mechanisms at work, not all which contribute to the observed decline in redistribution. One cautious policy implication could be that allowing for a flexible retirement age, e.g. a few years before the normal retirement age alongside the combination between work and reduced (e.g. life expectancyadjusted) pension income, may be one way to reduce the "need" for redistribution without compromising income adequacy and work incentives. ${ }^{77}$

\subsection{Illustrative reform scenarios}

In order to develop potential forward-looking policy reform avenues for OECD countries, empirical results are used to simulate the effect of selected tax and transfer reforms on income redistribution for the working-age population. The direction of the policy change is chosen so that the income redistribution effect is positive. In order to propose relatively realistic reform scenarios, avoid 'one-sizefits all' solutions, but at the same time remain simple, the simulations consider two benchmark cases depending on countries' relative starting point: ${ }^{78} 1$ ) the median of OECD countries, with the policy gap being closed for countries below this benchmark, 2) the upper quartile of OECD countries, with the policy gap being closed for countries below this benchmark but above the median. This is a highly stylised way to consider cross-country heterogeneity along with political economy and implementation obstacles and concerns.

One question is whether reforms to increase income redistribution would raise a trade-off between equity and efficiency objectives - e.g. the question of the efficiency of redistribution. Another relevant question is whether reforms to increase income redistribution would raise budgetary tensions and more generally their funding implications - e.g. the question of the cost-effectiveness of redistribution. These questions are very tentatively taken into account as follows: i) reforms are selected so as to minimise potential equity/ efficiency trade-offs, on the basis of recent literature findings, 79 and ii) in line with policy specifications throughout the paper, results illustrate tax/spending-neutral reforms in the sense that total tax revenue (in the case of taxes) and total social spending (in the case of transfers) are kept constant. As a result, such reforms may imply shifts between

76 Attempts to instrument this variable with policy parameters were not successful. Instrumenting it with its lagged value delivers similar findings with even a larger estimated effect.

${ }^{77}$ See OECD (2017c), Chapter 2 for a detailed discussion.

${ }^{78}$ The starting point is the latest available year for each policy indicator.

${ }^{79}$ For example Agkun et al (2017) who shed light on the effects of the tax mix on growth and income inequality. Yet the literature is not yet consensual on the effect of tax and transfer redistribution polices on economic performance: see Redistribution, inequality, and sustainable growth | VOX, CEPR's Policy Portal and Ostry et al (2014). 
and within the spending and revenue side of the budget. Still, these purely illustrative scenarios only provide an indicative direction of potential avenues for reform. Policy packages need to be fine-tuned at the country-level, taking into account country-specific context and social preferences; including the weight between equity and efficiency objectives alongside budgetary constraints. With all these caveats in mind, the following highly-stylised reform scenarios are considered (Figure 6 \& Figure 7):

- Increases in the overall progressivity of personal income taxes on wage earnings

- Increases in the top marginal rate on personal income and employees' social security contributions

- Increases in the net personal tax rate on dividend income -- which can be achieved not only by raising statutory rates but also by reducing tax reliefs and allowances

- Increases in long-term unemployment-related transfers for low-income married couples (including social assistance)

- Increases in public spending on childcare and early education

Tax reforms scenarios suggest substantive policy-driven redistribution gains in a number of Eastern European countries as well as in New Zealand (Figure 6, Panels A, B, C). This is because these countries feature relatively low levels of overall PIT progressivity, reflecting flat or close-to-flat PIT systems and consistently low taxation of top incomes and of dividend income at the personal level. While all countries feature positive top PIT marginal tax rates, some have null net dividend income taxation (Estonia and Slovak Republic) and others null PIT progressivity (Hungary). This implies that associated policy simulations correspond to "large" reform shocks which would likely be difficult to implement from a political economy perspective. High-tax countries such as the Nordics and most continental European countries are above or close to policy benchmark levels. So are some low-tax countries and in particular the United States, which reflects a relatively high level of PIT progressivity and (compared to most OECD countries) a larger role of taxes relative to transfers in inequality reduction. ${ }^{80}$

All these tax reform simulations imply an increase in the progressivity of personal income taxes. This may raise efficiency concerns, for instance by reducing incentives to increase work effort, promote entrepreneurship and innovation, especially among high-earners. As stressed before though, the literature is not conclusive on the efficiency effects of changes in PIT progressivity. ${ }^{81}$ Such effects

\footnotetext{
${ }^{80}$ Causa and Hermansen (2017).

${ }^{81}$ For example, on the one hand recent synthetic control method evidence on the efficiency and (top incomes) inequality effects of reductions in tax progressivity suggests no significant efficiency gains (Rubolino and Waldenstorm 2017); on the other, recent crosscountry regression evidence on the effects of the tax mix on inequality suggests that greater progressivity in the upper half of the income distribution, in the form of higher tax in the
} 
are fundamentally likely to depend on reform design and country context. Related to this consideration and going beyond, tax reform for inequality reduction should consider making the whole tax system more progressive and this implies looking at a variety of tax instruments beyond PIT. Such is the case of property taxation which is consensually less distortive than PIT and can in many OECD countries be made a more potent instrument of income redistribution than it currently is.

form of higher tax wedges on above average income earners, is linked with lower longterm output (Akgun et al 2017). 
Figure 6. Reform-driven changes in redistribution for the working-age population

A. Increases in the overall progressivity of personal income taxes on wage earnings

$\%$

2.5

2.0

- Closing the gap w ith the OECD median

Closing the gap with the OECD upper-quartile

1.5

1.0

0.5

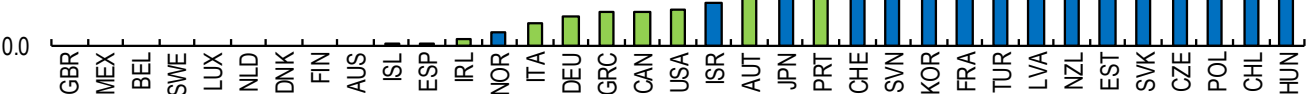

B. Increases in the top marginal rate on personal income and employees' social security contributions

$\%$

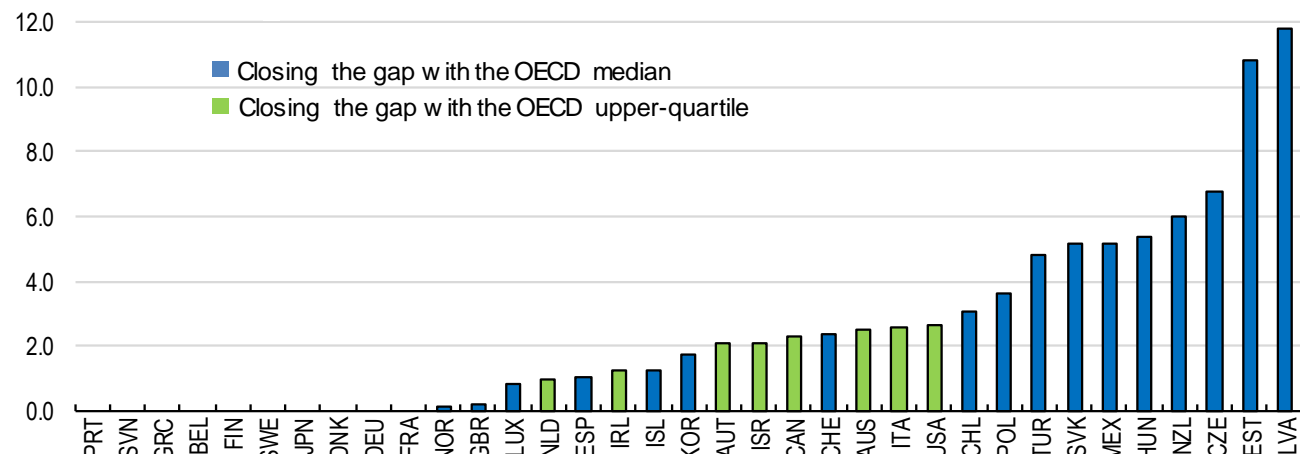

$\%$

C. Increases in the net personal tax on dividend income

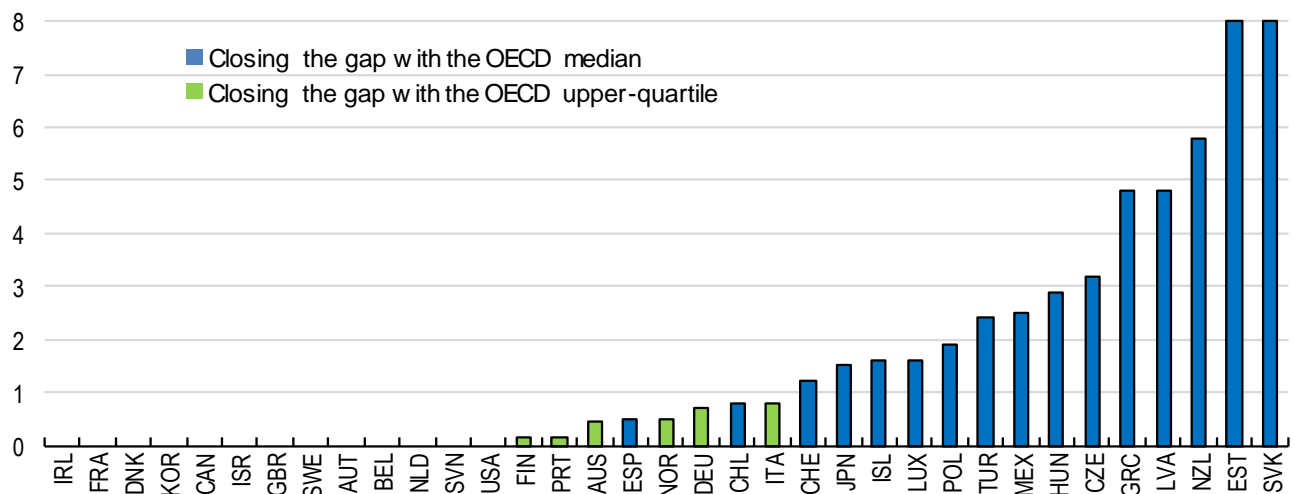

Note: Based on the latest available year for every country. As explained in the text, the simulations consider two benchmark cases depending on countries' relative starting point: 1) the median of OECD countries, with the policy gap being closed for countries below this benchmark, 2) the upper quartile of OECD countries, with the policy gap being closed for countries below this benchmark but above the median. Measured redistribution for HUN TUR and MEX only captures the impact of cash transfers.

Source: OECD staff calculations, see Appendix for data sources. 
Transfer reform scenarios deliver larger effects than tax reform scenarios (Figure 7, Panels A \& B) ${ }^{82}$ The scenarios consistently point to major redistribution gains in countries where social spending on working-age population is relatively low and/ or weakly targeted to low-income households. ${ }^{83}$ Increases in long-term unemployed- related transfers to married couples delivers major redistribution gains where these transfers are null ${ }^{84}$, i.e. Chile, Greece, Italy and Turkey, but also the United States where such transfers exists but are very low. The magnitude of these effects reflects the large implied size of the simulated reforms for these countries and should therefore be interpreted in light of alternative policy objectives, in particular efficiency objectives in terms of job search incentives, alongside budgetary constraints.

Still, those same countries that exhibit comparatively low passive support for the long-term unemployed tend to also exhibit comparatively low active support. ${ }^{85}$ As a result, policy packages that would combine more generous cash transfers with more effective activation and training for jobseekers would likely meet equity and efficiency objectives. The United States and Turkey would also boost redistribution by increasing spending on early education and childcare; and so would Mexico and Japan. This would not only increase redistribution but also help narrowing gender gaps and curbing child poverty. ${ }^{86}$ Reforms to enhance access to quality childcare for disadvantaged families are likely to maximise policy synergies between efficiency and equity.

${ }^{82}$ This may in part reflect that transfers account for the bulk of income redistribution in OECD countries. Causa and Hermansen, (2017), Brys, (2016), Immervoll and Richardson (2011).

${ }^{83}$ Causa and Hermansen (2017).

${ }^{84}$ On the basis of the last available year which is 2015; couples without children (OECD Benefits and Wages database).

${ }^{85}$ As measured by spending on ALMPs relative to GDP. This for instance applies to the United States, Chile and Italy.

${ }^{86}$ On the effects of early education and childcare spending on women employment, see Gal and Theising (2015), on inequality reduction see Causa et al (2015). On child poverty, see http://www.oecd.org/els/CO_2_2_Child_Poverty.pdf. 
Figure 7. Illustrative income redistribution effects of selected transfer reforms

Reform-driven changes in redistribution for the working-age population A. Increases in long-term unemployment-related transfers for low-income married couples (including social assistance)

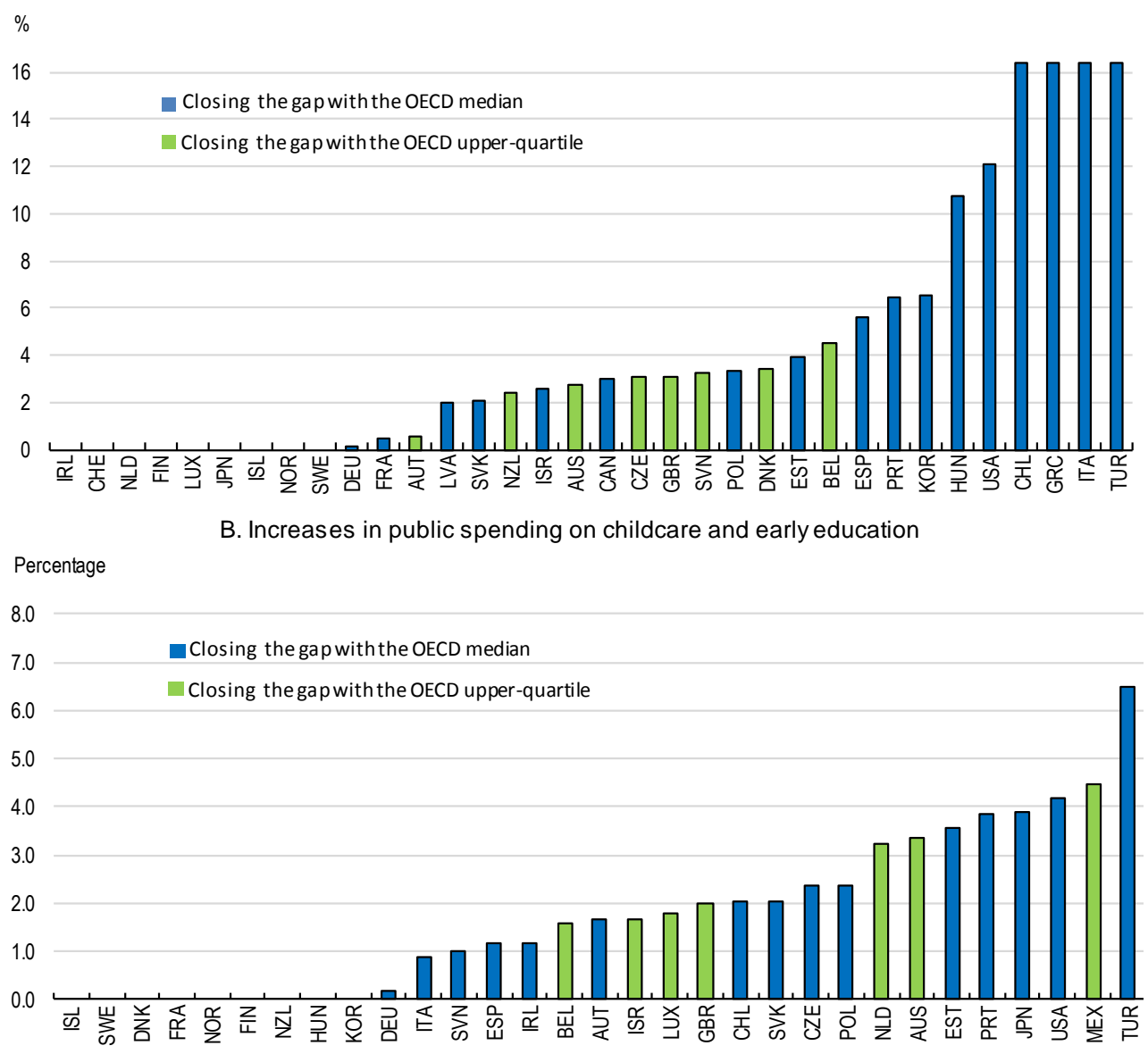

Note: Based on the latest available year for every country. As explained in the text, the simulations consider two benchmark cases depending on countries' relative starting point: 1) the median of OECD countries, with the policy gap being closed for countries below this benchmark, 2) the upper quartile of OECD countries, with the policy gap being closed for countries below this benchmark but above the median. Measured redistribution for HUN TUR and MEX only captures the impact of cash transfers. LVA is not shown in panel B due to data limitations.

Source: OECD staff calculations, see Appendix for data sources. 


\section{References}

Acemoglu, D. and D. Autor (2011), "Skills, Tasks and Technologies: Implications for Employment and Earnings", In: David Card and Orley Ashenfelter, eds., Handbook of Labor Economics, Volume 4, Part B. Amsterdam: Elsevier. pp. 1043-1171.

Acemoglu, D. and J.A. Robinson (2012), "Why Nations Fail: The Origins of Power, Prosperity and Poverty", New York, NY:Crown.

Acemoglu, D. and J.A. Robinson (2007), "Economic Origins of Dictatorship and Democracy", Cambridge University Press.

Akgun, O., B. Cournède and J. Fournier (2017), "The effects of the tax mix on inequality and growth”, OECD Economics Department Working Papers, No. 1447, OECD Publishing, Paris, http://dx.doi.org/10.1787/c57eaa14-en.

Alesina, A. and E. Glaeser (2004), "Fighting Poverty in the US and Europe: A World of Difference", Oxford University Press.

Alstadsaeter, A., Johannesen, N. and G. Zucman (2017), “Tax Evasion and Inequality”, NBER Working Paper No. w23772 https://ssrn.com/abstract=3035109.

Andersen, T.M. (2015), “The Welfare State and Economic Performance”, Låntidsudredningen 2015, Statens Offentliga Utredningar, Stockholm.

Arnold, J., B. Brys, C. Heady, Å. Johansson, C. Schwellnus and L. Vartia (2011), “Tax Policy For Economic Recovery and Growth", 121 Economic Journal F59-F80.

Berlingieri, G., P. Blanchenay and C. Criscuolo (2017), "The great divergence(s)", OECD Science, Technology and Industry Policy Papers, No. 39, OECD Publishing, Paris, http://dx.doi.org/10.1787/953f3853-en.

Borjas, G. (1999), “The economic analysis of immigration”, Handbook of labour Economics, 1999, vol 3, part A, pp. 1697-1760, Elsevier.

Bourguignon, F. and A. Spadaro (2006), "Microsimulation as a tool for evaluating redistribution policies", Journal of Economic Inequality, Vol. 4, pp. 77-106.

Bradley, D. et al. (2003), "Distribution and redistribution in postindustrial democracies", World Politics, Vol. 55, pp. 193-228.

Browne, J. and H. Immervoll (2018),"Have tax and transfer policies become less inclusive? Results from a microsimulation analysis", OECD Social, Employment and Migration Working Papers, forthcoming.

Brys, B., S. Perret, A. Thomas and P. O'Reilly (2016), “Tax Design for Inclusive Economic Growth", OECD Taxation Working Papers, No. 26, OECD Publishing, Paris, http://dx.doi.org/10.1787/5jlv74ggk0g7-en.

Card D. and J. E. Di Nardo (2002), "Skill-Biased Technological Change and Rising Wage inequality: some problems and Puzzles", Journal of Labour Economics, 2002, Vol. no. 4. 
Causa, O. and M. Hermansen (2017), "Income redistribution through taxes and transfers across OECD countries", OECD Economics Department Working Papers, No. 1453, OECD Publishing, Paris, http://dx.doi.org/10.1787/bc7569c6-en.

Causa, O., M. Hermansen and N. Ruiz (2016), "The Distributional Impact of Structural Reforms", OECD Economics Department Working Papers, No. 1342, OECD Publishing, Paris, http://dx.doi.org/10.1787/5jln041nkpwc-en.

Causa, O., A. de Serres and N. Ruiz (2015), "Can Pro-growth Policies Lift All Boats? An Analysis Based on Household Disposable Income", OECD Journal: Economic Studies, Vol. 2015, pp. 227-268, http://dx.doi.org/10.1787/eco_studies-2015-5jrqhbb1t5jb.

Dreher, A. (2005), "The influence of globalisation on taxes and social policy: an empirical analysis for OECD countries", European Journal of Political economy, Vol 22 (2006), 179201.

Egger, P., S. Nigai and N. Strecker (2016), "The taxing deed of globalisation”, CEPR Discussion paper DP11259.

Esping-Andersen, G. and J. Myles (2009), “The welfare state and redistribution”, in: B. Nolan, W. Salverda and T.M. Smeeding (eds.), Oxford Handbook of Economic Inequality, Oxford University Press.

Figari, F., A. Paulus and H. Sutherland (2015), "Microsimulation and policy analysis", in: F. Bourguignon and A.B. Atkinson, Handbook of Income Distribution, Vol. 2B, North-Holland.

Gal P. and A. Theising (2015) "The macroeconomic impact of structural policies on labour market outcomes in OECD countries", OECD Economics Department Working Papers, No. 1271, OECD Publishing, Paris, http://dx.doi.org/10.1787/5jrqc6t8ktjf-en

Gemmel N., R. Kneller and I. Sanz (2008), "Foreign investment, international trade and the size and structure of public expenditures" European Journal of Political Economy 24 151-171.

Geppert, C. (2018), "Financial Incentives from Recent and On-going Pension Reforms", OECD Working Paper, forthcoming.

Huber, E. and J. D. Stephens (2014), "Income Inequality and redistribution in post-industrial democracies: demographic, economic and political determinants", Socio-economic Review (2014), 12, 245-267. doi:10.1093/ser/mwu001.

IMF (2018), "Inequality and Poverty across Generations in the European Union", IMF Discussion Note SDN/18/01.

IMF (2017), “IMF Fiscal Monitor: Tackling Inequality”, October 2017.

Immervoll, H. and L. Richardson (2011), "Redistribution Policy and Inequality Reduction in OECD Countries: What Has Changed in Two Decades?", OECD Social, Employment and Migration Working Papers, No. 122, OECD Publishing, Paris, http://dx.doi.org/10.1787/5kg5dlkhjq0x-en.

Iversen, T. and D. Soskice (2006), "Electoral institutions and the politics of coalitions: Why some democracies redistribute more than others", American Political Science Review, Vol. 100/2, pp. $165-181$.

Joumard, I., M. Pisu and D. Bloch (2012), "Tackling Income Inequality: The Role of Taxes and Transfers", OECD Journal: Economic Studies, Vol. 2012/1, http://dx.doi.org/10.1787/eco_studies-2012-5k95xd6165lt.Kenworthy, L. and H. J. Pontusson 
(2005), "Rising inequality and the politics of redistribution in affluent countries", Perspectives on Politics, Vol. 3/3, pp. 449-471.

Kim, M. and R. Varsano (2008), "The "flat tax(es)": principles and experience", International Tax and Public Finance, 15, (6), 712-751.

Kleibergen, F. and Paap, R. (2006), "Generalized Reduced Rank Tests Using the Singular Value Decomposition”, Journal of Econometrics, Vol. 133, pp. 97-126.

Kwon, H. Y. and J. Pontusson (2010), "Globalisation, labour power and partisan politics revisited”, Socioeconomic Review (2010) 8, 215-281.

Lindert, P. (2004), "Growing public social spending and economic growth since the eighteenth century", Cambridge University Press, Cambridge.

Lupu, N. and J. Pontusson (2011), "The structure of inequality and the politics of redistribution", American Political Science Review, Vol. 105/2, pp. 316-336.

Georgiadis, A., \& Manning, A. (2007). "Spend it like Beckham? Inequality and redistribution in the United Kingdom, 1983-2004.”, CEP Discussion Paper No. 816Martinez-Vazquez, J., V. Vuolic and B. M. Dodson (2014), "The Impact of tax and Expenditure Policies on Income distribution: evidence from a large panel of countries", Economics faculty publications, Georgia State University.

Meinhard, S. and N. Potrafke (2012), "The Globalisation-Welfare State Nexus Reconsidered", Review of International Economics, 20(2), 271-2012. DOI:10.1111/j.1467-9396.2012.01021.x.

Meltzer, A. H. and S. F. Richard (1981), “A Rational Theory of the Size of Government”, Journal of Political Economy, Vol. 89/5, pp. 914-927.

Moene, K. O. and M. Wallerstein (2003), "Earnings inequality and welfare spending: A disaggregated analysis", World Politics, Vol. 55/4, pp. 485-516.

Moene, K. O. and M. Wallerstein (2001), "Inequality, Social Insurance and Redistribution", The American Political Science Review, Vol. 95, No.4, pp. 859-874. OECD (2018a), "The Role and Design of Net Wealth Taxes in the OECD”, OECD Tax Policy Studies, No. 26, OECD Publishing, Paris, http://dx.doi.org/10.1787/9789264290303-en.

OECD (2018b), "Good Jobs for all in a changing world: the OECD Jobs strategy", OECD Publishing, Paris forthcoming.

OECD (2017a), “Economic Policy Reforms 2017: Going for Growth”, OECD Publishing, Paris, http://dx.doi.org/10.1787/growth-2017-en.

OECD (2017b), “OECD Employment Outlook 2017”, OECD Publishing, Paris. http://dx.doi.org/10.1787/empl_outlook-2017-en.

OECD (2017c), "Pensions at a glance: OECD and G20 Indicators", OECD Publishing, Paris, http://dx.doi.org/10.1787/pension_glance-2017-en.

OECD (2016), "Income Inequality Update 2016: Income Inequality Remains High in the Face of Weak Recovery", OECD Publishing, Paris.

OECD (2015), “In It Together: Why Less Inequality Benefits All”, OECD Publishing, Paris, http://dx.doi.org/10.1787/9789264235120-en.

OECD (2014), “Taxing Wages 2014”, OECD Publishing, Paris, http://dx.doi.org/10.1787/tax_wages-2014-en.

OECD (2011), "Divided We Stand: Why Inequality Keeps Rising”, OECD Publishing, http://dx.doi.org/10.1787/9789264119536-en. 
Onaran, O. and V. Boesch (2014), "The effect of globalisation on the distribution of taxes and social expenditures in Europe: do welfare state regime matter?" Environment and Planning A 2014 vol 46, p/ 373-397.

Piketty, T., E. Saez and G. Zucman (2016), "Distributional National Accounts: Methods and Estimates for the United States", NBER Working Paper Series, No. 22945.

Potrafke, N. (2015), "The evidence on globalisation", The World Economy, doi:10.1111/twec.12174.

Potrafke, N. (2009), "Did globalization restrict partisan politics? An empirical evaluation of social expenditures in a panel of OECD countries", Public Choice, 140: 105-124.

Rodrik, D. (2011), "The Globalization Paradox - Democracy and the Future of the World Economy"

New York: W.W. Norton \& Company.

Rodrik, D. (1998), "Why do more open economies have bigger governments?" Journal of Political Economy 106 997-1032.

Romer, T. (1975), "Individual Welfare, Majority Voting and the Properties of a Linear Income Tax”, Journal of Public Economics, Vol. 4/2, pp. 163-185.

Rubolino, E. and D. Waldenstorm (2017), "Tax Progressivity and Top Incomes: Evidence from Tax Reforms", IZA Discussion Paper Series, No. 10666, Institute for the Study of Labour (IZA), Bonn.

Schwellnus, C., A. Kappeler and P. Pionnier (2017), "Decoupling of wages from productivity: Macro-level facts", OECD Economics Department Working Papers, No. 1373, OECD Publishing, Paris, http://dx.doi.org/10.1787/d4764493-en.

Scruggs, L., D. Jahn and K. Kuitto (2017), "Comparative Welfare Entitlements Dataset 2. Version 2017-09." University of Connecticut \& University of Greifswald.

Swank, D. (2015), "The political foundations of redistribution in post-industrial democracies", LIS Working Paper Series, No. 653.

Tanninen H., M. Tuomala and E. Tuominen (2017), "Inequality, redistributional preferences, and the extent of redistribution", Seventh Meeting of the Society for the Study of Economic Inequality (ECINEQ) 17.07.2017. New York, USA. 


\section{Annex A.}

Table A.1. Data sources

\begin{tabular}{|c|c|c|}
\hline Variable types & Variables & Source \\
\hline \multicolumn{3}{|c|}{ Dependent variable } \\
\hline Redistribution & $\frac{(\text { Gini market income }- \text { Gini disposable income })}{\text { Gini maket income }}$ & $\begin{array}{l}\text { OECD calculation based on the OECD IDD } \\
\text { database }\end{array}$ \\
\hline \multicolumn{3}{|c|}{ Non-policy drivers of redistribution } \\
\hline Unemployment & $\begin{array}{l}\text { Unemployment rate, Long-term Unemployment (Incidence of } \\
\text { unemployment for } 1 \text { year and over), Employment Rate }\end{array}$ & OECD Labour Force Statistics Database \\
\hline \multirow{2}{*}{$\begin{array}{l}\text { Socio-demographic } \\
\text { composition }\end{array}$} & $\begin{array}{l}\text { Youth dependency rate, Old-age dependency rate, Working } \\
\text { age population }\end{array}$ & $\begin{array}{l}\text { United Nations, Department of Economic } \\
\text { and Social Affairs, Population Division } \\
\text { (2017). World Population Prospects: The } \\
2017 \text { Revision }\end{array}$ \\
\hline & $\begin{array}{l}\text { Share of lone parents among working-age households, } \\
\text { Share of families with children among working-age } \\
\text { households, Share of workless families with children among } \\
\text { working-age households }\end{array}$ & OECD IDD Database \\
\hline \multirow{2}{*}{ Inequality } & D9D1, D9D5, D5D1 & OECD Labour market earnings \\
\hline & Gini of market income & OECD IDD Database \\
\hline \multirow{3}{*}{ Politics } & Left-wing government parties' seat share & CPDS Political setting and partisanship \\
\hline & Voter turnout & $\begin{array}{l}\text { Comparative Political Data Set } 1960-2015 \\
\text { (CPDS). }\end{array}$ \\
\hline & Union density & ICTWSS Database \\
\hline \multirow{5}{*}{$\begin{array}{l}\text { Globalisation and } \\
\text { technological } \\
\text { change }\end{array}$} & \begin{tabular}{|l}
$\begin{array}{l}\text { Exports, Imports, Openness } \\
\text { (import+export)/gdp*100) }\end{array}$ \\
\end{tabular} & OECD ADB Database \\
\hline & Imported value added to final demand & $\begin{array}{l}\text { OECD calculations based on OECD trade in } \\
\text { value added database (Tiva) }\end{array}$ \\
\hline & Migration inflow, Migration stock & $\begin{array}{l}\text { OECD International Migration Database } \\
\text { (B11, B15) }\end{array}$ \\
\hline & TFP change & Penn World Table version 9.0 (PWT) \\
\hline & Temporary employment & $\begin{array}{l}\text { OECD, LFS - Employment by Permanency } \\
\text { database }\end{array}$ \\
\hline \multicolumn{3}{|c|}{ Tax parameters } \\
\hline $\begin{array}{l}\text { Overall progressivity } \\
\text { of PIT }\end{array}$ & $\begin{array}{l}\text { Overall structural progression of personal income taxes on } \\
\text { wage earnings, Average effective tax rates from } 67 \% \text { to } \\
500 \% \text { of the AW }\end{array}$ & OECD, Taxing Wages Database. \\
\hline $\begin{array}{l}\text { Taxation of top } \\
\text { incomes \& of capital } \\
\text { income }\end{array}$ & $\begin{array}{l}\text { Top statutory personal income tax rates, Top marginal tax } \\
\text { rates - PIT, Top marginal tax rates - PIT \& employee SSC, } \\
\text { Net personal tax on dividend income, Share of overall tax rate } \\
\text { on dividend income collected through the use of PIT }\end{array}$ & OECD, Tax Database \\
\hline $\begin{array}{l}\text { Tax revenues and } \\
\text { tax structure }\end{array}$ & $\begin{array}{l}\text { Total Tax revenues, Tax revenue share from PIT, Tax revenue } \\
\text { share from employees' SSC, Tax revenue share from goods } \\
\text { and services, Tax revenue share from production, sale } \\
\text { transfer, Tax revenue share from use of goods and perform, } \\
\text { Tax revenue share fax revenue share from property, Tax } \\
\text { revenue share from Recurrent taxes on immovable property, } \\
\text { Tax revenue share from Recurrent taxes on net wealth, Tax } \\
\text { revenue share from Estate, inheritance and gift taxes, Tax } \\
\text { revenue share from taxes on financial and capital } \\
\text { transactions, Tax revenue share from Non-recurrent taxes on } \\
\text { property }\end{array}$ & OECD, Revenue Statistics Database \\
\hline
\end{tabular}


Table A.2. Data sources, continued

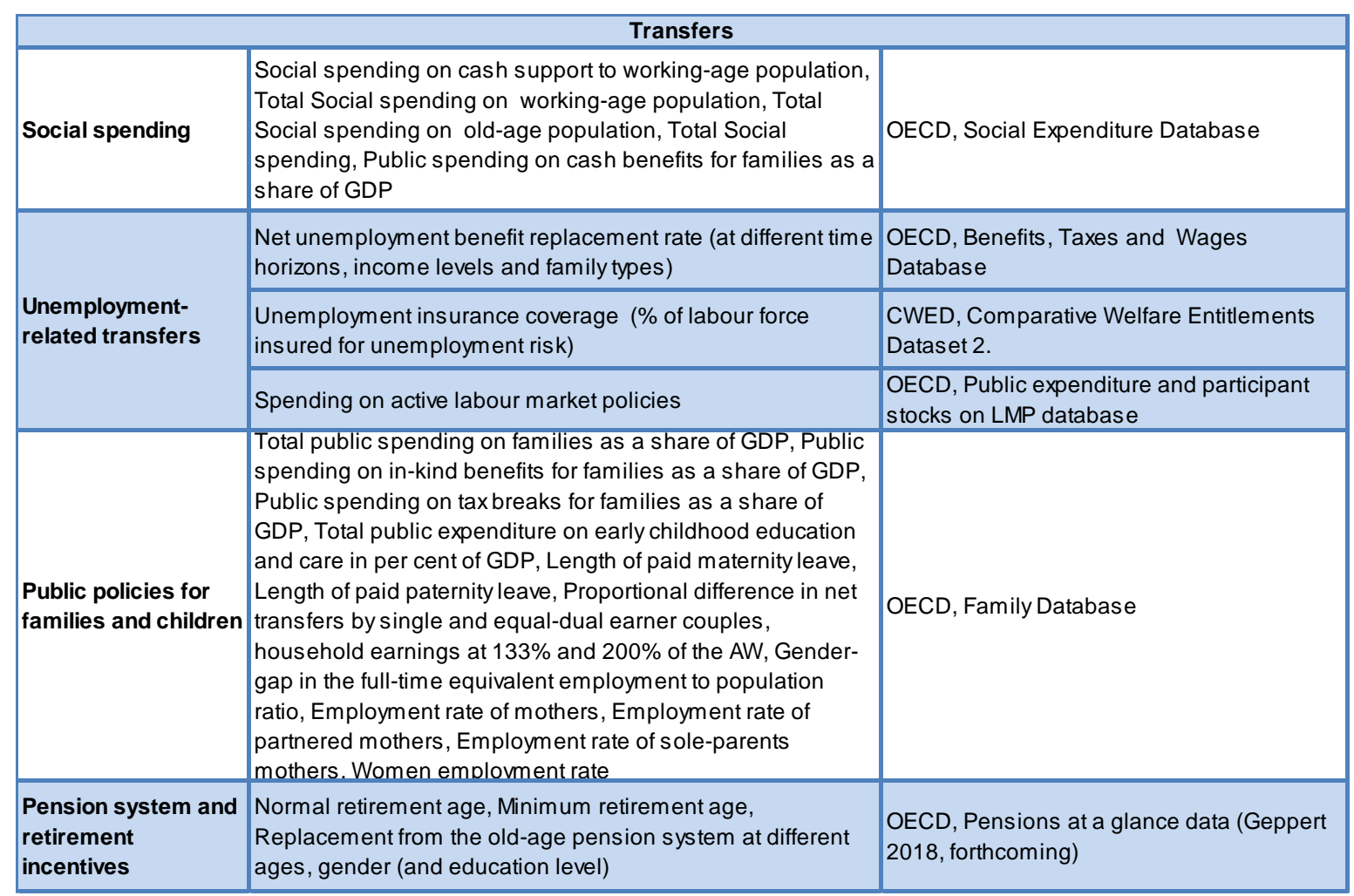


Table A.3. Data coverage in the OECD Income Distribution Database - version 201617 of 13 July 2017

The OECD Income Distribution Database (IDD) is the source of the dependent variable: income redistribution through taxes and transfers among working-age households (calculated using the disposable income Gini after taxes and transfers and the market income Gini before taxes and transfers) as well as some of the independent variables (sociodemographic composition of workingage households).

The IDD provides summary measures of income inequality and semi-aggregate statistics for household income components by disposable income deciles.

The database covers all 35 OECD countries with various degrees of time coverage.

\begin{tabular}{|c|c|c|c|c|}
\hline Country & First Year & Last Year & Periodicity & \# Observations \\
\hline AUS & 1990 & 2014 & Every 5 years, then biennial & 7 \\
\hline AUT & 2004 & 2014 & Annual & 11 \\
\hline BEL & 2004 & 2014 & Annual & 11 \\
\hline CAN & 1990 & 2014 & Annual & 25 \\
\hline CHE & 2009 & 2012 & Annual & 4 \\
\hline CHL & 2006 & 2015 & Biennial & 5 \\
\hline CZE & 1996 & 2014 & 1996, 2002, then annually from 2004 & 13 \\
\hline DEU & 1990 & 2014 & Every 5 years, then annually from 2008 & 11 \\
\hline DNK & 1990 & 2014 & Every 5 years, then annually from 2005 & 13 \\
\hline ESP & 2004 & 2014 & Annual & 11 \\
\hline EST & 2004 & 2014 & Annual & 11 \\
\hline FIN & 1990 & 2015 & Annual & 26 \\
\hline FRA & 1996 & 2014 & Every 5 years, then annually from 2008 & 10 \\
\hline GBR & 1990 & 2015 & Every 5 years, then annually from 1999 & 19 \\
\hline GRC & 2004 & 2014 & Annual & 11 \\
\hline HUN & 2007 & 2014 & Biennial & 4 \\
\hline IRL & 2004 & 2014 & Annual & 11 \\
\hline ISL & 2004 & 2014 & Annual & 11 \\
\hline ISR & 1990 & 2015 & Every 5 years, then annually from 2008 & 12 \\
\hline ITA & 1991 & 2014 & Every 5 years, then annually from 2006 & 13 \\
\hline JPN & 1995 & 2012 & Every 5 then every 3 years & 6 \\
\hline KOR & 2006 & 2015 & Annual & 10 \\
\hline LUX & 2004 & 2014 & Annual & 11 \\
\hline LVA & 2004 & 2014 & Annual & 11 \\
\hline MEX & 2012 & 2014 & Biannual & 2 \\
\hline NLD & 1990 & 2015 & Every 5 years, then annually from 2005 & 14 \\
\hline NOR & 1995 & 2014 & Every 5 years, then annually from 2008 & 10 \\
\hline NZL & 1990 & 2014 & Every 5 years, then biennial & 9 \\
\hline POL & 2005 & 2014 & Annual & 10 \\
\hline PRT & 2004 & 2014 & Annual & 11 \\
\hline SVK & 2004 & 2014 & Annual & 11 \\
\hline SVN & 2004 & 2014 & Annual & 11 \\
\hline SWE & 1991 & 2014 & Every 4 years, then biennial & 11 \\
\hline TUR & 2011 & 2014 & Annual & 4 \\
\hline USA & 1995 & 2015 & Every 5 years, then annually from 2008 & 11 \\
\hline
\end{tabular}




\section{Additional results: baseline estimates without country fixed effects}

Table A.4. Redistribution: the effects of labour market conditions and the socio-demographic composition of working-age households - baseline results without country fixed effects

\begin{tabular}{|c|c|c|c|c|c|c|c|c|c|c|c|c|c|c|c|c|c|}
\hline Dependent variable is $\ln$ (redistribution) & 1 & 2 & 3 & 4 & 5 & 6 & 7 & 8 & 9 & 10 & 11 & 12 & 13 & 14 & 15 & 16 & 17 \\
\hline \multicolumn{18}{|l|}{$\begin{array}{l}\text { Labour market conditions } \\
\text { In (Unemployment rate) }\end{array}$} \\
\hline In (Unemployment rate) & $0.29^{\star}$ & 0.09 & $0.51^{*}$ & 0.26 & $0.23^{*}$ & 0.22 & $0.32^{\star *}$ & $0.24^{\star}$ & $0.29^{*}$ & $0.32^{\star \star \star}$ & $0.37^{\star \star \star}$ & $0.28^{\star \star}$ & $0.32^{\star \star}$ & & & $0.23^{\star \star}$ & $0.23^{\star \star}$ \\
\hline & $(0.14)$ & $(0.14)$ & $(0.25)$ & $(0.17)$ & $(0.13)$ & $(0.13)$ & $(0.15)$ & $(0.13)$ & $(0.14)$ & $(0.11)$ & $(0.12)$ & $(0.12)$ & $(0.14)$ & & & $(0.09)$ & $(0.09)$ \\
\hline Long-term unemployment & & $0.86^{\star \star}$ & & & & & & & & & & & & & & & \\
\hline Emoloument rats & & $(0.39)$ & & & & & & & & & & & & & & & \\
\hline Employment rate & & & $\begin{array}{l}2.14 \\
(1.58)\end{array}$ & & & & & & & & & & & & & & \\
\hline \multirow{2}{*}{\multicolumn{18}{|c|}{$\begin{array}{l}\text { Demographic and socioeconomic conditions } \\
\text { Youth dependency rate }\end{array}$}} \\
\hline & & & & -1.48 & & -0.36 & & & & & & & & & & & \\
\hline & & & & $(1.03)$ & & $(1.07)$ & & & & & & & & & & & \\
\hline Old-age dependency rate & & & & & $3.28^{* *}$ & 3.07 & & & & & & & & & & & \\
\hline & & & & & $(1.60)$ & $(1.82)$ & & & & & & & & & & & \\
\hline Share of lone parents among working-age households & & & & & & & 1.78 & & & & & & & & & & \\
\hline & & & & & & & (1.95) & & & & & & & & & & \\
\hline Share of families with children among working-age households & & & & & & & & $-2.83^{\text {** }}$ & & & & & & & & & \\
\hline & & & & & & & & $(1.22)$ & & & & & & & & & \\
\hline Share of workless families with children among working-age households & & & & & & & & & $\begin{array}{l}0.65 \\
(1.40)\end{array}$ & $\begin{array}{l}2.99 \\
(1.97)\end{array}$ & $\begin{array}{l}2.56 \\
(1.94)\end{array}$ & $\begin{array}{l}2.43 \\
(2.00)\end{array}$ & $\begin{array}{l}0.98 \\
(1.92)\end{array}$ & $\begin{array}{l}3.42 \\
(2.36)\end{array}$ & $\begin{array}{l}0.26 \\
(1.86)\end{array}$ & $\begin{array}{l}1.11 \\
(1.94)\end{array}$ & $\begin{array}{l}0.89 \\
(1.85)\end{array}$ \\
\hline \multirow{2}{*}{\multicolumn{18}{|c|}{$\begin{array}{l}\text { Income inequality before taxes and transfers } \\
\text { Earnings inequality: } \ln (d 9 d 1)\end{array}$}} \\
\hline & & & & & & & & & & $-0.96^{\star \star \star}$ & & & & $-0.92^{\star \star \star}$ & & -0.19 & \\
\hline & & & & & & & & & & $(0.23)$ & & & & $(0.27)$ & & $(0.32)$ & \\
\hline $\ln (d 9 d 5)$ & & & & & & & & & & & $-1.76^{\star \star \star}$ & & & & & & \\
\hline & & & & & & & & & & & $(0.51)$ & & & & & & \\
\hline $\ln (\mathrm{d} 5 \mathrm{~d} 1)$ & & & & & & & & & & & & $-1.01^{\star \star}$ & & & & & \\
\hline & & & & & & & & & & & & $(0.38)$ & & & & & \\
\hline Gini market income & & & & & & & & & & & & & -0.61 & & 1.26 & & \\
\hline Government partisanship and union power & & & & & & & & & & & & & (2.52) & & $(2.45)$ & & \\
\hline $\begin{array}{l}\text { 'Govert-wing gov. parties' seat share } \\
\text { Lefter }\end{array}$ & & & & & & & & & & & & & & & & 598 & 721 \\
\hline & & & & & & & & & & & & & & & & $(8.93)$ & (8.70) \\
\hline Union density & & & & & & & & & & & & & & & & 0.40 & $0.49^{*}$ \\
\hline Voter turnout & & & & & & & & & & & & & & & & $(0.30)$ & $(0.25)$ \\
\hline & & & & & & & & & & & & & & & & $\begin{array}{l}0.13 \\
(0.40)\end{array}$ & $\begin{array}{l}0.25 \\
(0.32)\end{array}$ \\
\hline Time fixed effects & Yes & Yes & Yes & Yes & Yes & Yes & Yes & Yes & Yes & Yes & Yes & Yes & Yes & Yes & Yes & Yes & Yes \\
\hline Country fixed effects & No & No & No & No & No & No & No & No & No & No & No & No & No & No & No & No & No \\
\hline Observations & 380 & 371 & 380 & 380 & 380 & 380 & 380 & 380 & 380 & 362 & 362 & 362 & 380 & 362 & 381 & 300 & 311 \\
\hline R squared & 0.23 & 0.34 & 0.27 & 0.26 & 0.34 & 0.34 & 0.24 & 0.38 & 0.23 & 0.44 & 0.48 & 0.31 & 0.23 & 0.35 & 0.17 & 0.31 & 0.30 \\
\hline
\end{tabular}

Note: Dependent variable is the natural logarithm of redistribution. Standard errors are clustered at the country level.

Significance levels: $* \mathrm{p}<.1 ; * * \mathrm{p}<.05 ; * * * \mathrm{p}<.01$

Bold highlights significant coefficients 
Table A.5. Redistribution: the effects of technological change and globalisation - baseline results without country fixed effects

\begin{tabular}{|c|c|c|c|c|c|c|c|}
\hline Dependent variable is $\ln$ (redistribution to working-age population) & 1 & 2 & 3 & 4 & 5 & 6 & 7 \\
\hline \multicolumn{8}{|l|}{ Globalisation \& technological change } \\
\hline \multirow{2}{*}{ In (openness) } & $0.32^{\star \star \star}$ & & & & $0.28^{\star \star \star}$ & $0.30^{\star \star \star}$ & $0.32^{\star \star \star}$ \\
\hline & $(0.08)$ & & & & $(0.07)$ & $(0.07)$ & $(0.07)$ \\
\hline \multirow[t]{2}{*}{ In (exports) } & & $0.29^{\star \star \star}$ & & & & & \\
\hline & & $(0.07)$ & & & & & \\
\hline \multirow[t]{2}{*}{ In (imports) } & & & $0.34^{\star \star \star}$ & & & & \\
\hline & & & $(0.08)$ & & & & \\
\hline \multirow[t]{2}{*}{ In (imported value added to final demand) } & & & & $0.46^{\star \star \star}$ & & & \\
\hline & & & & $(0.14)$ & & & \\
\hline \multirow[t]{2}{*}{ In (inflows of migrants relative to of working-age population) } & & & & & 0.01 & & \\
\hline & & & & & $(0.05)$ & & \\
\hline \multirow[t]{2}{*}{ In (stock of migrants relative to of working-age population) } & & & & & & 0.01 & \\
\hline & & & & & & $(0.03)$ & \\
\hline \multirow{2}{*}{ In (MFP change) } & -0.53 & -0.52 & -0.53 & -0.38 & -0.63 & -0.33 & -0.31 \\
\hline & $(0.49)$ & $(0.52)$ & $(0.48)$ & $(0.53)$ & $(0.52)$ & $(0.43)$ & $(0.43)$ \\
\hline \multicolumn{8}{|l|}{ Changes in the nature of work } \\
\hline \multirow{2}{*}{ Share of temporary employment in total employment } & & & & & & & -0.71 \\
\hline & & & & & & & $(0.87)$ \\
\hline \multicolumn{8}{|l|}{ Labour market, sociodemographic conditions and earnings inequality } \\
\hline \multirow[t]{2}{*}{ In (Unemployment rate) } & $0.31^{\star \star \star}$ & $0.32^{\star \star \star}$ & $0.29^{\star \star \star}$ & $0.27^{\star *}$ & $0.33^{\star \star \star}$ & $0.30^{\star \star}$ & $0.31^{\star \star \star}$ \\
\hline & $(0.10)$ & $(0.10)$ & $(0.11)$ & $(0.12)$ & $(0.12)$ & $(0.11)$ & $(0.11)$ \\
\hline \multirow[t]{2}{*}{ Earnings inequality: In (d9d1) } & $-0.93^{\star \star \star}$ & $-0.89^{\star \star \star}$ & $-0.97^{\star \star \star}$ & $-0.97^{\star \star \star}$ & $-0.94^{\star \star \star}$ & $-0.89^{\star \star \star}$ & $-0.97^{\star \star \star}$ \\
\hline & $(0.24)$ & $(0.24)$ & $(0.24)$ & $(0.23)$ & $(0.25)$ & $(0.24)$ & $(0.23)$ \\
\hline \multirow[t]{2}{*}{ Share of workless families with children among working-age households } & $3.08^{\star \star}$ & $2.98^{\star \star}$ & $3.17^{\star \star}$ & $2.52^{\star}$ & $3.91^{\star \star}$ & $3.63^{\star \star}$ & $2.93^{\star \star}$ \\
\hline & $(1.42)$ & $(1.40)$ & $(1.46)$ & $(1.35)$ & $(1.41)$ & $(1.49)$ & $(1.37)$ \\
\hline Time fixed effects & Yes & Yes & Yes & Yes & Yes & Yes & Yes \\
\hline Country fixed effects & No & No & No & No & No & No & No \\
\hline Observations & 357 & 357 & 357 & 254 & 345 & 302 & 319 \\
\hline R squared & 0.55 & 0.54 & 0.55 & 0.46 & 0.51 & 0.61 & 0.55 \\
\hline
\end{tabular}

Note: Dependent variable is the natural logarithm of redistribution. Standard errors are clustered at the country level.

Significance levels: $* \mathrm{p}<.1 ; * * \mathrm{p}<.05 ; * * * \mathrm{p}<.01$

Bold highlights significant coefficients 


\section{$\underline{\text { Robustness tests }}$}

Robustness tests range from controlling for additional variables in fixed effects regressions to alternative estimation methods. These are summarized as follows:

- Controlling for potential common cyclical movements between redistribution and policy variables using additional explanatory variables:

○ Output gap

○ GDP growth

- Lagging different sets of explanatory variables:

$\circ \quad$ All explanatory variables lagged

- Policy variables (tax revenue, social spending and policy parameters) lagged

- Policy variables (tax revenue, social spending and policy parameters) and earnings inequality lagged

- Instrumental variables (IV) regressions: using first lags of different sets of explanatory variables as instruments for their contemporaneous values in fixed effects regressions:

$\circ \quad$ Instrumenting all explanatory variables

$\circ \quad$ Instrumenting policy variables (tax revenue, social spending and policy parameters)

$\circ \quad$ Instrumenting policy variables (tax revenue, social spending and policy parameters) and earnings inequality

- Quantile (median) regressions, estimated with country fixed effects.

The first three tests address endogeneity concerns associated with the explanatory variables. The last test addresses outlier i.e. influential observations: in the case of a skewed conditional distribution, median regressions provide more robust inference on the slope parameters compared to the usual conditional expectation regression.

This battery of robustness tests indicate that the results presented in the main paper are largely robust. In this Annex only a subset of these tests are reported, the rest being available upon request. The reported tests are: i) controlling for GDP growth (Tables 3-9), ii) instrumenting policy variables (Tables 10-16) and, iii) median regressions (Tables 1723). IV regressions are reported with two diagnostic tests: Kleibergen and Paap (KP) ${ }^{87}$ to check the validity of the lagged policy variables as instruments, and difference-in-Sargan as a measure of the distance between fixed effects and IV estimates. If the KP test validates the instruments by rejecting the null hypothesis of under identification, the choice between fixed effects and IV estimates can be done using difference-in-Sargan statistics. The null hypothesis of this test states that the policy variables are exogenous. Hence rejecting this hypothesis can be interpreted as evidence against the fixed effects regressions.

${ }^{87}$ Kleibergen and Paap (2006). 
The results reported in the main paper are overall strongly robust to controlling for cyclical variables, lags and influential observations. In terms of statistical significance, a few policy variables can be identified as having a less robust effect than others, especially in IV regressions. Those variables are:

- Total social spending as a share of GDP,

- Overall structural progression of personal income taxes on wage earnings,

- Share of overall tax rate on dividend income collected through the use of PIT,

- Women minimum retirement age and replacement rate from the old-age pension system at age 69 .

In the case of total social spending, adding GDP growth results in a slightly smaller slope estimate and higher variance. GDP growth is never statistically significant in the regressions, an indication that this variable may introduce some noise in the estimates. $\mathrm{KP}$ and Difference-in-Sargan tests indicate that the fixed effect regressions are preferred over the IV regressions. In median regressions, the estimated effect of total social spending is similar to that of the fixed effect regressions, in most cases even of higher magnitude. Hence, the results on total social spending reported in the main paper can be considered confirmed by the robustness tests.

The fact that the effect of the overall structural progression of personal income taxes on wage earnings is relatively sensitive to the robustness tests should not dismay the paper's finding of strong redistributive effects from tax progressivity. Indeed, all the other complementary measures of progressivity (e.g. top statutory personal income tax rates, top marginal tax rates, dividend income taxation) exhibit very robust effects. The less robust effect of the overall structural progression of personal income taxes on wage earnings may reflect measurement issues associated with that indicator, as suggested in the main text. Furthermore, as with total social spending, diagnostic tests conclude in favour of the fixed effects regressions.

The effect of the share of overall tax rate on dividend income collected through the use of PIT becomes statistically insignificant in IV regressions. However, again diagnostic tests point to the superiority of fixed effects results over IV regressions. Furthermore, there is still evidence of a statistically significant effect in median regressions. A similar pattern emerges for the effects of women minimum retirement age and that of replacement rates from the old-age pension system at age 69 . 
Table A.6. Redistribution: the effects of social spending and tax revenues - controlling for GDP growth

\begin{tabular}{|c|c|c|c|c|c|c|c|c|c|c|c|}
\hline Dependent variable is $\ln$ (redistribution) & 1 & 2 & 3 & 4 & 5 & 6 & 7 & 8 & 9 & 10 & 11 \\
\hline \multicolumn{12}{|l|}{ Social spending (in $\%$ of GDP) } \\
\hline Social spending on cash support to working-age population & $4.12^{\star \star}$ & & & & & & $3.29^{\star \star}$ & & $3.16^{\star \star}$ & & $3.27^{\star \star}$ \\
\hline Total Social spending on workinq-age population & $(1.55)$ & & & & & & (1.47) & & $(1.42)$ & & (1.49) \\
\hline 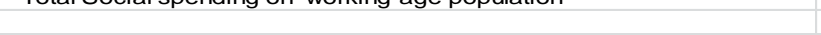 & & $(1.10)$ & & & & & & & & & \\
\hline Total Social spending on old-age population & & -0.24 & & & & & & & & & \\
\hline Total Social spending & & $(2.26)$ & & & & & & & & & \\
\hline Total Soclal Spenaing & & & $(0.98)$ & & & & & $(0.94)$ & & $(0.89)$ & \\
\hline \multicolumn{12}{|l|}{ Tax revenues (in $\%$ of GDP) } \\
\hline Tax revenues from PIT and employees' SSC & & & & $2.88^{\star \star \star}$ & & & $1.94^{\star \star}$ & & $2.05^{\star \star}$ & & $2.03^{\star \star}$ \\
\hline Tax revenues from $\mathrm{PT}$ & & & & $(0.70)$ & $3.23^{\star * *}$ & & $(0.76)$ & & $(0.77)$ & & $(0.75)$ \\
\hline & & & & & $(1.02)$ & & & & & & \\
\hline Tax revenues from employees' SSC & & & & & 1.19 & & & & & & \\
\hline & & & & & (1.41) & & & & & & \\
\hline Total Tax revenues & & & & & & 0.64 & & 0.13 & & 0.23 & \\
\hline & & & & & & $(0.75)$ & & $(0.68)$ & & $(0.70)$ & \\
\hline \multirow{2}{*}{\multicolumn{12}{|c|}{$\begin{array}{l}\text { Interaction between openness and (*): } \\
\text { Tax revenues from PIT and employees' SSC }\end{array}$}} \\
\hline & & & & & & & & & $-1.90^{\star \star \star}$ & & \\
\hline Total tax revenues & & & & & & & & & 10.001 & $-0.98^{*}$ & \\
\hline & & & & & & & & & & $(0.53)$ & \\
\hline Social spending on cash support to working-age population & & & & & & & & & & & -1.69 \\
\hline & & & & & & & & & & & $(1.15)$ \\
\hline \multicolumn{12}{|l|}{ Technological change \& Globalisation } \\
\hline Ln (openness) & $\begin{array}{l}\mathbf{0 . 2 1}^{\star \star} \\
(0.087)\end{array}$ & $\begin{array}{l}0.23^{\star} \\
(0.11)\end{array}$ & $\begin{array}{l}0.19^{\star} \\
(0.098)\end{array}$ & $(0.086)$ & $\begin{array}{l}0.081 \\
.0 .074)\end{array}$ & $=0.18$ & $\begin{array}{l}0.091 \\
(0.077)\end{array}$ & $\begin{array}{l}0.19 \\
(0.12)\end{array}$ & $(0.085)$ & $=0.17$ & $\begin{array}{c}0.082 \\
(0.071)\end{array}$ \\
\hline Ln (MFP change) & $-0.41^{\star \star}$ & $-0.40^{\star \star}$ & $-0.32^{\star}$ & $-0.38^{\star \star}$ & $-0.34^{\star \star}$ & $-0.40^{\star \star}$ & $-0.36^{\star \star}$ & -0.31 & $-0.37^{\star \star}$ & -0.29 & $-0.31^{\star}$ \\
\hline \multirow{2}{*}{\multicolumn{12}{|c|}{ Labour market, sociodemographic conditions and earnings inequality }} \\
\hline & & & & & & & & & & & \\
\hline & $(0.039)$ & (0.039) & $(0.043)$ & $(0.024)$ & $(0.025)$ & )$(0.027)$ & $(0.038)$ & $(0.041)$ & $(0.036)$ & (0.039) & $(0.037)$ \\
\hline Earnings inequality: In (d9d1) & $-0.51^{\star \star \star \star}$ & - $-0.59^{\star \star \star *}$ & $-0.44^{\star \star}$ & $-0.36^{\star *}$ & $-0.36^{\star \star}$ & $-0.43^{\star \star \star}$ & $-0.42^{\star \star}$ & $-0.43^{\star *}$ & $-0.35^{\star}$ & $-0.41^{\star *}$ & $-0.39^{* *}$ \\
\hline & $(0$. & $(0.21)$ & $(0$. & & $(0.15)$ & $\because(0$. & $(0.18)$ & $(0.16)$ & $(0.18)$ & $(0.16)$ & $(0.17)$ \\
\hline Share of workless families with children among working-age households" & 1.3 & & 1. & & 1. & 1. & $1.38^{*}$ & 1.13 & & 1.15 & $1.63^{\star}$ \\
\hline & $(0.91)$ & $(0.92)$ & $(0.90)$ & $(0.88)$ & $(0.87)$ & $(0.98)$ & $(0.78)$ & $(0.90)$ & $(0.74)$ & $(0.92)$ & $(0.86)$ \\
\hline GDP growth & -0.18 & -0.18 & -0.15 & -0.21 & -0.17 & -0.31 & -0.100 & -0.15 & -0.097 & -0.14 & -0.13 \\
\hline Tim & 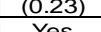 & 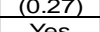 & $(0.28)$ & & $(0.20)$ & $(0.24)$ & $(0.20)$ & $(0.29)$ & $(0.20)$ & $(0.29)$ & $(0.19)$ \\
\hline & $\begin{array}{l}\text { Yes } \\
\text { Yes }\end{array}$ & Yes & $\begin{array}{l}\text { res } \\
\text { Yes }\end{array}$ & $\begin{array}{l}\text { res } \\
\text { Yes }\end{array}$ & $\begin{array}{l}\text { Yes } \\
\text { Yes }\end{array}$ & $\begin{array}{l}\text { Yes } \\
\text { Yes }\end{array}$ & $\begin{array}{l}\text { Yes } \\
\text { Yes }\end{array}$ & Yes & Yes & Yes & Yes \\
\hline Observation & 328 & 328 & 356 & 344 & 344 & 35 & 318 & 356 & 318 & $\begin{array}{l}\text { res } \\
356\end{array}$ & $\begin{array}{l}318 \\
318\end{array}$ \\
\hline R squared & 0.543 & 0.535 & 0.512 & 0.524 & 0.528 & " 0.491 & 0.561 & 0.512 & 0.574 & 0.519 & 0.566 \\
\hline
\end{tabular}

Note: Dependent variable is the natural logarithm of redistribution. Standard errors are clustered at the country level. (*) Every variable in the interactions is demeaned. R squared does not incorporate the effect of country fixed effects.

Significance levels: $* \mathrm{p}<.1 ; * * \mathrm{p}<.05 ; * * * \mathrm{p}<.01$

Bold highlights significant coefficients 
Table A.7. Taxes and redistribution: a focus on the overall progressivity of personal income taxes on wage earnings - controlling for GDP growth

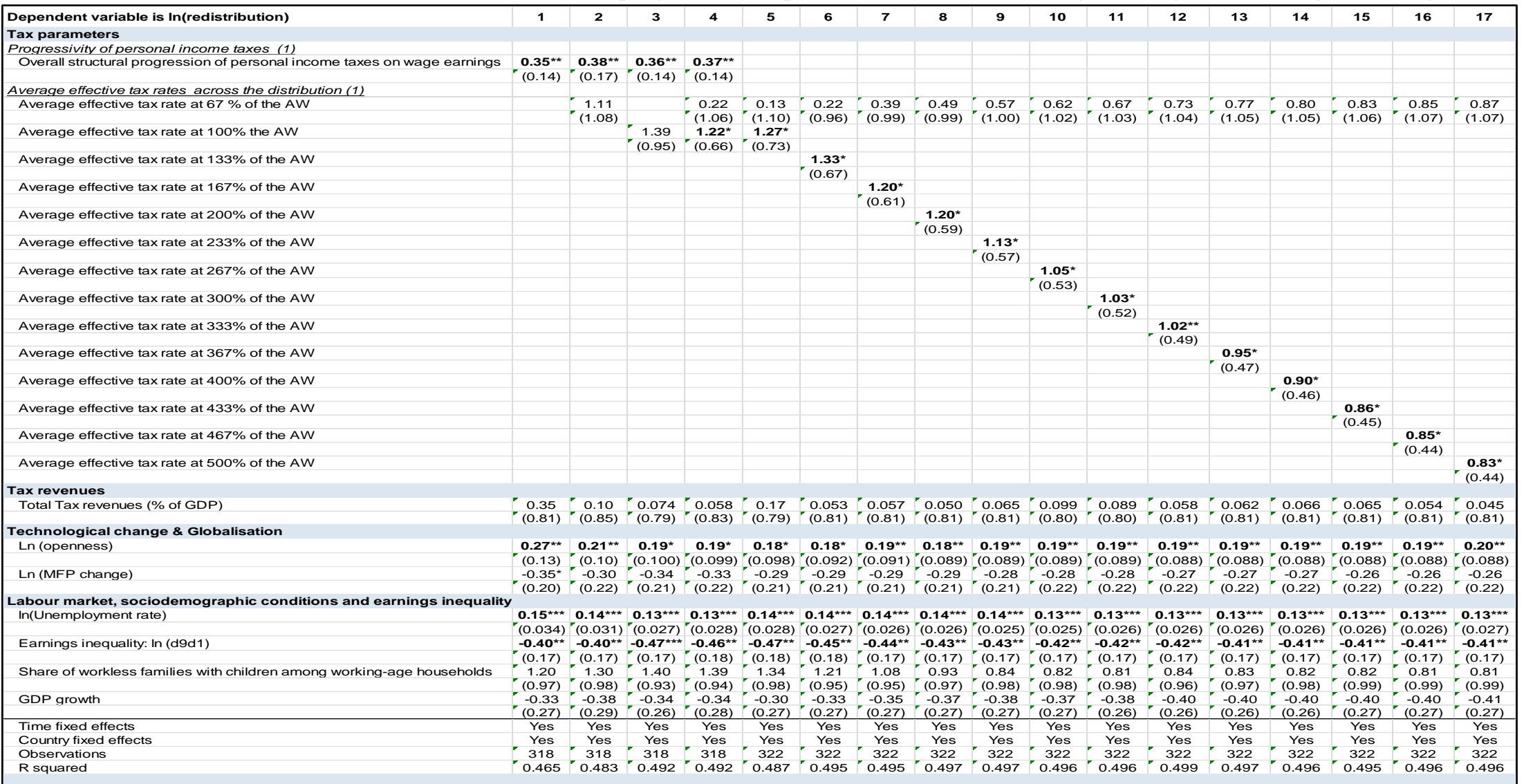

Note: Dependent variable is the natural logarithm of redistribution. Standard errors are clustered at the country level. R squared does not incorporate the effect of country fixed effects. (1) Data refer to single taxpayers without children.

Significance levels: $* \mathrm{p}<.1 ; * * \mathrm{p}<.05 ; * * * \mathrm{p}<.01$

Bold highlights significant coefficients 
Table A.8. Taxes and redistribution: a focus on top tax rates and on the taxation of capital income - controlling for GDP growth

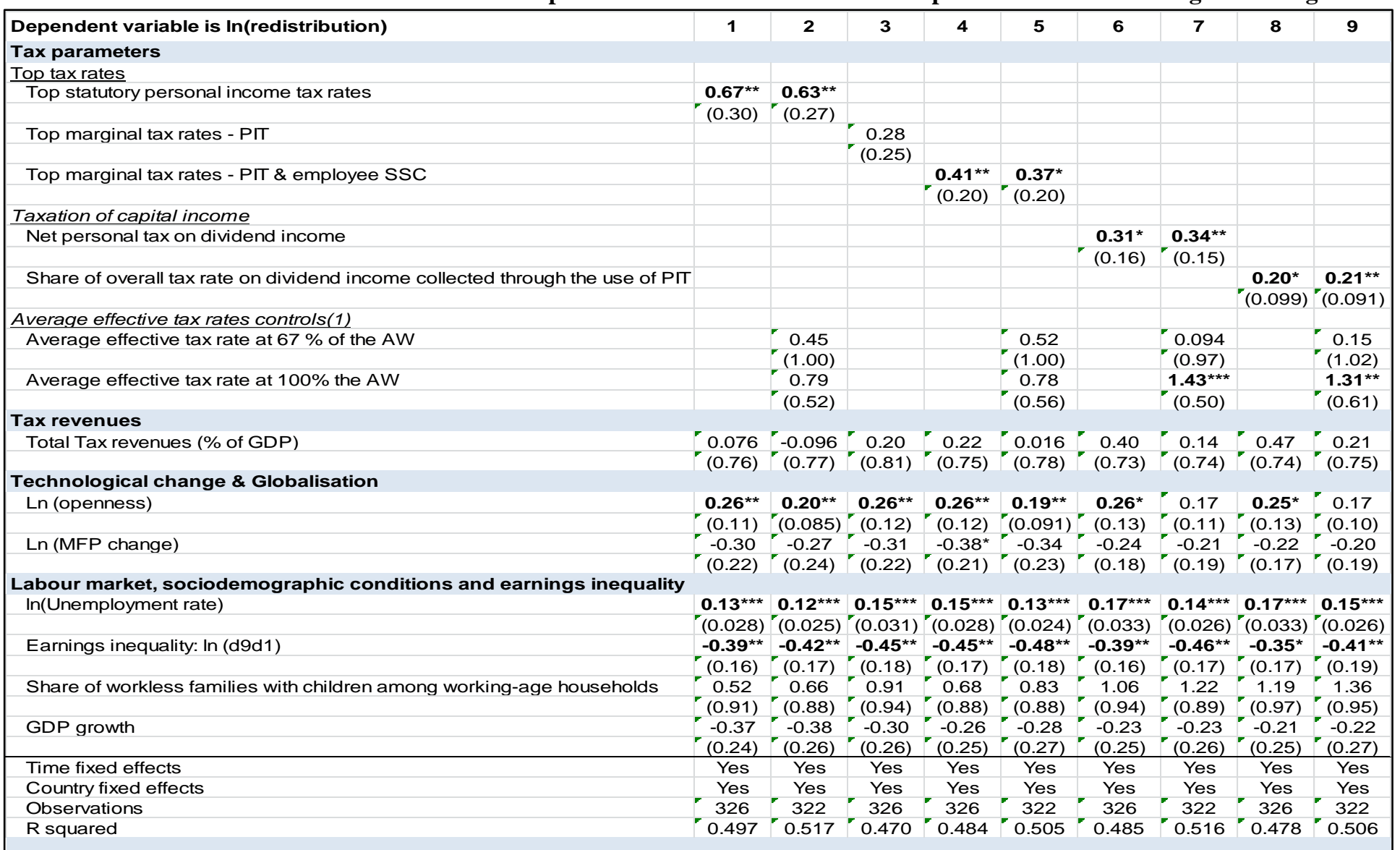

Note: Dependent variable is the natural logarithm of redistribution. Standard errors are clustered at the country level. R squared does not incorporate the effect of country fixed effects. (1) Data refer to single taxpayers without children.

Significance levels: * $p<.1 ; * * p<.05 ; * * * p<.01$

Bold highlights significant coefficients 
Table A.9. The tax structure and income redistribution - controlling for GDP growth

\begin{tabular}{|c|c|c|c|c|c|c|}
\hline Dependent variable is $\ln$ (redistribution) & 1 & 2 & 3 & 4 & 5 & 6 \\
\hline \multicolumn{7}{|l|}{ Tax structure (\% of Total Tax revenue) } \\
\hline \multirow[t]{2}{*}{ Tax revenue share from PIT and employees' SSC } & $0.90^{\star \star \star}$ & & & & & \\
\hline & $(0.32)$ & & & & & \\
\hline \multirow[t]{2}{*}{ From PIT } & & $1.00^{\star \star}$ & & & & \\
\hline & & $(0.43)$ & & & & \\
\hline \multirow[t]{2}{*}{ From employees' SSC } & & 0.58 & & & & \\
\hline & & $(0.54)$ & & & & \\
\hline \multirow[t]{2}{*}{ Tax revenue share from goods and services } & & & $-1.52^{\star *}$ & $-1.48^{\star \star}$ & & \\
\hline & & & $(0.63)$ & $(0.55)$ & & \\
\hline \multirow[t]{2}{*}{ From production, sale transfer } & & & & & $-1.19^{\star *}$ & $-1.20^{* *}$ \\
\hline & & & & & $(0.54)$ & $(0.54)$ \\
\hline \multirow[t]{2}{*}{ From use of goods and perform } & & & & & $-5.15^{\star *}$ & $-4.98^{\star *}$ \\
\hline & & & & & $(2.36)$ & $(2.21)$ \\
\hline \multirow[t]{2}{*}{ Tax revenue share from property } & & & 0.97 & & & 0.45 \\
\hline & & & $(1.26)$ & & & $(1.08)$ \\
\hline \multirow[t]{2}{*}{ From Recurrent taxes on immovable property } & & & & 1.64 & & \\
\hline & & & & $(2.13)$ & & \\
\hline \multirow[t]{2}{*}{ From Recurrent taxes on net wealth } & & & & 4.15 & & \\
\hline & & & & $(4.43)$ & & \\
\hline \multirow[t]{2}{*}{ From Estate, inheritance and gift taxes } & & & & 1.08 & & \\
\hline & & & & $(5.38)$ & & \\
\hline \multirow[t]{2}{*}{ From taxes on financial and capital transactions } & & & & -1.16 & & \\
\hline & & & & $(2.22)$ & & \\
\hline \multirow[t]{2}{*}{ From Non-recurrent taxes on property } & & & & 3.41 & & \\
\hline & & & & $(3.50)$ & & \\
\hline \multicolumn{7}{|l|}{ Tax revenues (\% of GDP) } \\
\hline \multirow[t]{2}{*}{ Total Tax revenues } & $1.36^{\star \star \star}$ & $1.30^{\star \star *}$ & 0.23 & 0.38 & 0.32 & 0.31 \\
\hline & $(0.49)$ & $(0.44)$ & $(0.60)$ & $(0.72)$ & $(0.46)$ & $(0.45)$ \\
\hline \multicolumn{7}{|l|}{ Technological change \& Globalisation } \\
\hline \multirow[t]{2}{*}{ Ln (openness) } & 0.067 & 0.068 & $0.23^{\star \star}$ & $0.20^{\star \star}$ & $0.19^{\star *}$ & $0.20^{* *}$ \\
\hline & $(0.083)$ & $(0.083)$ & $(0.11)$ & '(0.089) & $(0.083)$ & )$(0.084)$ \\
\hline \multirow[t]{2}{*}{ Ln (MFP change) } & $-0.33^{\star}$ & $-0.31^{\star}$ & $-0.52^{\star \star}$ & $-0.48^{\star \star}$ & $-0.48 * \star$ & $-0.47^{\star *}$ \\
\hline & $(0.18)$ & $(0.17)$ & $(0.21)$ & $(0.21)$ & $(0.20)$ & $(0.20)$ \\
\hline \multicolumn{7}{|c|}{ Labour market, sociodemographic conditions and earnings inequality } \\
\hline \multirow[t]{2}{*}{ In(Unemployment rate) } & $0.13^{\star * *}$ & $0.13^{\star \star \star}$ & $0.14^{\star \star \star}$ & $0.12^{\star \star \star}$ & $0.14^{\star \star \star}$ & $0.14^{\star \star \star}$ \\
\hline & $(0.025)$ & $(0.026)$ & $(0.024)$ & $(0.034)$ & $(0.024)$ & )$(0.024)$ \\
\hline \multirow[t]{2}{*}{ Earnings inequality: $\ln (\mathrm{d} 9 \mathrm{~d} 1$ ) } & $-0.34^{\star \star}$ & $-0.34^{\star \star}$ & $-0.47^{\star \star \star}$ & * $-0.45^{\star \star \star}$ & $-0.51^{\star \star \star}$ & * -0.50 *** \\
\hline & $(0.15)$ & $(0.15)$ & $(0.15)$ & $(0.16)$ & $(0.16)$ & $(0.16)$ \\
\hline \multirow[t]{2}{*}{ Share of workless families with children among working-age households } & 1.13 & 1.10 & 0.72 & 0.55 & 1.02 & 0.99 \\
\hline & $(0.94)$ & $(0.95)$ & $(0.97)$ & $(0.95)$ & $(1.00)$ & $(0.99)$ \\
\hline GDP growth & -0.14 & -0.14 & -0.29 & -0.30 & -0.25 & -0.27 \\
\hline & $(0.21)$ & $(0.21)$ & $(0.21)$ & $(0.22)$ & $(0.22)$ & $(0.22)$ \\
\hline Time fixed effects & Yes & Yes & Yes & Yes & Yes & Yes \\
\hline Country fixed effects & Yes & Yes & Yes & Yes & Yes & Yes \\
\hline Observations & 344 & 344 & 357 & 357 & 357 & 357 \\
\hline R squared & 0.526 & 0.527 & 0.542 & 0.555 & 0.555 & 0.555 \\
\hline
\end{tabular}

Note: Dependent variable is the natural logarithm of redistribution. Standard errors are clustered at the country level. R squared does not incorporate the effect of country fixed effects.

Significance levels: $* \mathrm{p}<.1 ; * * \mathrm{p}<.05 ; * * * \mathrm{p}<.01$

Bold highlights significant coefficients 
Table A.10. Transfers and redistribution: a focus on unemployment-related transfers - controlling for GDP growth

\begin{tabular}{|c|c|c|c|c|c|c|c|c|c|c|c|c|c|c|}
\hline Dependent variable is $\ln$ (redistribution) & 1 & 2 & 3 & 4 & 5 & 6 & 7 & 8 & 9 & 10 & 11 & 12 & 13 & 14 \\
\hline \multirow{2}{*}{\multicolumn{15}{|c|}{$\begin{array}{l}\text { Transfer parameters } \\
\text { Net unemployment benefit replacement rate (1) }\end{array}$}} \\
\hline & & & & & & & & & & & & & & \\
\hline \multirow[t]{2}{*}{ Over 5 years - at $100 \%$ of the AW, married couple } & $0.72^{\star}$ & & & & & & & 0.26 & & & $0.74^{\star \star \star}$ & & & \\
\hline & $(0.36)$ & & & & & & & $(0.24)$ & & & $(0.20)$ & & & \\
\hline Over 5 years - at $150 \%$ of the AW, married couple & & $\begin{array}{l}0.65 \\
(0.49)\end{array}$ & & & & & & & & & & & & \\
\hline \multirow[t]{2}{*}{ Over 5 years - at $67 \%$ of the AW, married couple } & & & $0.55^{\star \star}$ & & & & & & 0.25 & & & $0.56^{\star \star \star}$ & & \\
\hline & & & $(0.24)$ & & & & & & $(0.17)$ & & & $(0.12)$ & & \\
\hline Initial - at $100 \%$ of the AW, married couple & & & & 0.35 & & & & & & & & & & \\
\hline \multirow{2}{*}{ Initial - at $67 \%$ of the $\mathrm{AW}$, married couple } & & & & $(0.24)$ & 0.11 & & & & & & & & & \\
\hline & & & & & $(0.16)$ & & & & & & & & & \\
\hline \multirow[t]{2}{*}{ Long-term- at $100 \%$ of the $\mathrm{AW}$, married couple } & & & & & & $0.59^{*}$ & & & & & & & & \\
\hline & & & & & & $(0.32)$ & & & & & & & & \\
\hline Long-term- at $67 \%$ of the AW, married couple & & & & & & & $(0.24)$ & & & $(0.16)$ & & & $(0.13)$ & $(0.13)$ \\
\hline \multirow[t]{2}{*}{ Unemployment insurance coverage (2) } & & & & & & & & & & & $0.74^{\star \star}$ & $0.77^{\star \star}$ & $0.70^{\star}$ & $0.98^{\star \star \star x}$ \\
\hline & & & & & & & & & & & $(0.33)$ & $(0.32)$ & $(0.38)$ & $(0.31)$ \\
\hline \multicolumn{15}{|l|}{ Social spending (in $\%$ of GDP) } \\
\hline Spending on active labour market policies (3) & & & & & & & & $\begin{array}{l}-11.9^{*} \\
(6.50)\end{array}$ & $\begin{array}{l}-12.2^{*} \\
(6.08)\end{array}$ & $-12.6^{\star \star}$ & & & & $\begin{array}{l}-13.8^{* \star} \\
(5.92)\end{array}$ \\
\hline Total Social spending & $\begin{array}{l}-0.13 \\
(1.03)\end{array}$ & $:-0.069$ & $=\frac{-0.13}{(1.02)}$ & .0 .094 & $: \begin{array}{l}0.12 \\
(1.07)\end{array}$ & $\begin{array}{l}-0.036 \\
(1.05)\end{array}$ & -0.017 & $\begin{array}{l}1.25 \\
(0.80)\end{array}$ & $\begin{array}{c}=1.20 \\
1.0 .78)\end{array}$ & $\begin{array}{l}1.28 \\
(0.81)\end{array}$ & 0.59 & 0.44 & 0.68 & $\begin{array}{l}=0.40 \\
0 \\
(1.07)\end{array}$ \\
\hline \multicolumn{15}{|l|}{ Technological change \& Globalisation } \\
\hline \multirow[t]{2}{*}{ Ln (openness) } & $0.22^{\star \star \star}$ & $0.24^{\star \star \star}$ & $0.21^{\star \star \star}$ & $0.24^{\star \star \star}$ & $0.26^{\star \star}$ & $0.22^{\star \star \star}$ & $0.20^{\star \star \star}$ & $0.14^{\star \star \star}$ & $0.13^{\star \star}$ & $0.14^{\star \star \star}$ & $0.18^{\star *}$ & $0.15^{*}$ & $0.18^{* \star}$ & $0.15^{\star \star}$ \\
\hline & (0.072) & $(0.082)$ & $(0.069)$ & (0.086) & , & , & $(0.067)$ & $(0.048)$ & $(0.047)$ & $(0.046)$ & $(0.073)$ & $(0.076)$ & $(0.071)$ & $(0.058)$ \\
\hline Ln (MFP change) & $\begin{array}{l}-0.15 \\
(0.22)\end{array}$ & -0.15 & -0.15 & -0.12 & -0.12 & -0.12 & -0.098 & -0.097 & -0.089 & -0.10 & -0.31 & -0.30 & $=0.30$ & -0.084 \\
\hline \multicolumn{15}{|l|}{ Labour } \\
\hline \multirow[t]{2}{*}{ In (Unemployment rate) } & $0.17^{\star \star \star}$ & $0.16^{\star \star \star}$ & $0.17^{\star \star \star}$ & $0.17^{\star \star \star}$ & $0.17^{\star \star \star}$ & $0.17^{\star \star \star}$ & $0.17^{\star \star \star}$ & $0.14^{\star \star \star}$ & $0.14^{\star \star \star}$ & $0.14^{\star \star \star}$ & 0.096 & 0.10 & 0.11 & $0.18^{\star \star \star}$ \\
\hline & $(0.036)$ & $(0.037)$ & $(0.036)$ & $(0.037)$ & $(0.039)$ & $(0.036)$ & $(0.036)$ & $(0.030)$ & '(0.031) & $(0.031)$ & $(0.071)$ & $(0.072$ & $(0.074)$ & $(0.048)$ \\
\hline \multirow[t]{2}{*}{ Earnings inequality: I I (d9d1) } & $-0.52^{\star \star \star}$ & $-0.51^{\star \star \star}$ & $-0.51^{\star \star}$ & $-0.54^{\star \star \star}$ & $-0.50^{\star \star *}$ & $-0.51^{\star \star \star}$ & $-0.52^{\star \star \star}$ & $-0.47^{\star \star}$ & $-0.47^{\star \star}$ & $-0.48^{\star \star}$ & $-0.75^{\star \star}$ & $-0.74^{\star \star}$ & $-0.75^{\star \star}$ & -0.59 \\
\hline & $(0.19)$ & $(0.18)$ & $(0.19)$ & $(0.19)$ & $(0.18)$ & $(0.19)$ & $(0.19)$ & $(0.22)$ & $(0.22)$ & $(0.22)$ & $(0.34)$ & $(0.34)$ & $(0.36)$ & $(0.35)$ \\
\hline \multirow[t]{2}{*}{ Share of workless families with children among working-age households } & 1.17 & 1.40 & 1.13 & 1.83 & 1.75 & 1.13 & 1.06 & 1.25 & 1.15 & 1.21 & $1.80^{*}$ & $1.85^{*}$ & 1.85 & 1.52 \\
\hline & $(1.32)$ & $(1.36)$ & $(1.30)$ & $(1.24)$ & $(1.25)$ & $(1.33)$ & $(1.37)$ & $(1.27)$ & $(1.26)$ & $(1.27)$ & $(1.06)$ & $(1.05)$ & $(1.09)$ & $(0.96)$ \\
\hline \multirow[t]{2}{*}{ GDP growth } & -0.29 & -0.31 & -0.29 & -0.21 & -0.28 & -0.27 & -0.25 & -0.011 & -0.0028 & -0.0063 & -0.32 & -0.29 & -0.26 & -0.29 \\
\hline & $(0.24)$ & $(0.24)$ & $(0.24)$ & $(0.24)$ & $(0.25)$ & $(0.23)$ & $(0.23)$ & $(0.25)$ & $(0.25)$ & $(0.25)$ & $(0.31)$ & $(0.31)$ & ' $(0.34)$ & $(0.37)$ \\
\hline Time fi & YES & YES & YES & YES & YES & YES & YES & YES & YES & YES & YES & YES & YES & YES \\
\hline ed effects & YES & YES & YES & YES & YES & YES & YES & YES & YES & YES & YES & YES & YES & YES \\
\hline Observations & 304 & 304 & 304 & 304 & 304 & 304 & 304 & 272 & 272 & 272 & 152 & 152 & 152 & 142 \\
\hline R squared & 0.551 & 0.534 & 0.549 & 0.521 & 0.509 & 0.541 & 0.542 & 0.504 & 0.509 & 0.505 & 0.592 & 0.595 & 0.580 & 0.636 \\
\hline
\end{tabular}

Note: Dependent variable is the natural logarithm of redistribution. Standard errors are clustered at the country level. R squared does not incorporate the effect of country fixed effects. (1) Families without children. (2) \% of labour force insured for unemployment risk. (3) Active measures only (categories 10-70).

Significance levels: $* \mathrm{p}<.1 ; * * \mathrm{p}<.05 ; * * * \mathrm{p}<.01$, Bold highlights significant coefficients 
Table A.11. Transfers and redistribution: a focus on public policies for families and children - controlling for GDP growth

\begin{tabular}{|c|c|c|c|c|c|c|c|c|c|c|c|c|c|c|}
\hline Dependent variable is $\ln$ (redistribution) & 1 & 2 & 3 & 4 & 5 & 6 & 7 & 8 & 9 & 10 & 11 & 12 & 13 & 14 \\
\hline \multirow{2}{*}{\multicolumn{15}{|c|}{$\begin{array}{l}\text { Policy indicators } \\
\text { Total public spending on families as a share of GDP }\end{array}$}} \\
\hline & $\begin{array}{r}2.00 \\
(3.16)\end{array}$ & & & & & & & & & & & & & \\
\hline \multicolumn{15}{|l|}{ Public spending on cash benefits for families as a share of GDP } \\
\hline Public spending on in-kind benefits for families as a share of GDP & & $(4.58)$ & 7.01 & & & & & & & & & & & \\
\hline & & & & (6.30) & & & & & & & & & & \\
\hline Public spending on early childhood education and care as a share of GDP & & & & & $16.4^{* \star}$ & & & & & & & & & \\
\hline & & & & & (7.46) & & & & & & & & & \\
\hline Length of paid maternity leave & & & & & & $0.094^{*}$ & & & & & & & & \\
\hline Length of paid paternity leave & & & & & & (0.046) & 0.11 & & & & & & & \\
\hline Proportional difference in net transfers by single and equal-dual earner couples, household earnings at $133 \%$ of the $\mathrm{AW}$ & & & & & & & & $0.0021^{*}$ & & & & & & \\
\hline Proportional difference in net transfers by single and equal-dual earner couples, household earnings at $200 \%$ of the $\mathrm{AW}$ & & & & & & & & & -0.43 & & & & & \\
\hline \multirow{2}{*}{\multicolumn{15}{|c|}{$\begin{array}{l}\text { Labour market situation of women } \\
\text { Gender-gap in the full-time equivalent employment to population ratio }\end{array}$}} \\
\hline & & & & & & & & & & & & & & \\
\hline Fmplovmentrate of mothers & & & & & & & & & & $(0.72)$ & & & & \\
\hline Empioyment rate or motners & & & & & & & & & & & $0.54^{*}$ & & & \\
\hline Employment rate of partnered mothers & & & & & & & & & & & & $0.63^{\text {** }}$ & & \\
\hline Employment rate of sole-parents mothers & & & & & & & & & & & & $(0.30)$ & & \\
\hline & & & & & & & & & & & & & $=(0.18)$ & \\
\hline \multicolumn{15}{|l|}{ Women employment rate } \\
\hline Social spending (in\% of GDP) & & & & & & & & & & & & & & (0.59) \\
\hline \\
\hline Ln (openness) & 0.21 & $0.21^{\star *}$ & $0.26^{* *}$ & $0.21^{\star}$ & $0.30^{\star \star}$ & $0.24^{* *}$ & 0.18 & $0.27^{\star \star}$ & $0.30^{* *}$ & $0.31^{\star \star}$ & $0.17^{* *}$ & $0.14^{*}$ & $0.14^{\star}$ & $0.19^{*}$ \\
\hline Ln (MFP change) & 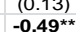 & 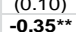 & $(0.11)$ & $(0.12)$ & * $\begin{array}{l}(0.12) \\
-0.38^{\star *}\end{array}$ & $\times(0.096)$ & $=(0.11)$ & $=\begin{array}{r}(0.10) \\
-0.089\end{array}$ & $=0.11)$ & $\begin{array}{c}(0.13) \\
-0.32^{\star *}\end{array}$ & * $=\frac{(0.064)}{-0.14}$ & $\begin{array}{l}0.079) \\
-0.079\end{array}$ & $.0 .071)$ & ),$(0.099)$ \\
\hline & $(0.23)$ & $(0.17)$ & $(0.15)$ & $(0.23)$ & $(0.17)$ & $(0.27)$ & $(0.25)$ & $(0.20)$ & $(0.22)$ & $(0.15)$ & $(0.14)$ & $(0.14)$ & $(0.14)$ & $(0.20)$ \\
\hline \multicolumn{15}{|l|}{$\begin{array}{l}\text { Labour market, sociodemographic conditions and earnings inequality } \\
\ln \text { (Unemployment rate) }\end{array}$} \\
\hline In (Unemployment rate) & $0.18^{\star \star \star}$ & $0.097^{\star \star}$ & $0.15^{\star \star \star}$ & $0.18^{* \star *}$ & * $0.12^{\star \star \star}$ & ${ }^{*} 0.10^{* *}$ & $0.12^{\star *}$ & $0.16^{\text {***}}$ & $0.15^{\star \star \star}$ & 0.043 & $0.15^{\star \star \star}$ & $0.15^{\star \star \star}$ & $0.13^{\star \star \star}$ & $0.12^{*+*}+>>>0$ \\
\hline Earnings inequality: $\ln (\mathrm{d} 9 \mathrm{~d} 1$ ) & 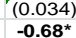 & "(0.047) & $(0.040)$ & 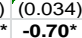 & )$_{-0.53^{\star \star \star *}}^{(0.03)}$ & 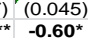 & )$^{\prime}(0.043)$ & $\begin{array}{l}(0.038) \\
-0.50^{\star \star *}\end{array}$ & $\left(\begin{array}{ll}(0.034) \\
-0.55 * x\end{array}\right)$ & $(0.048)$ & ) $)_{-0.44 * \star}^{(0.036)}$ & ) $)_{-0.42 * \star}^{(0.039)}$ & )$(0.045)$ & 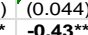 \\
\hline & $(0.35)$ & & & $(0.35)$ & $(0.19)$ & $(0.30)$ & $(0.29)$ & $(0.18)$ & $(0.19)$ & $(0.17)$ & $(0.17)$ & $(0.17)$ & $(0.18)$ & $(0.17)$ \\
\hline Share of workless families with children among working-age households & 1.27 & 1.25 & 1.61 & 1.21 & 0.90 & 0.94 & 0.88 & 2.13 & 1.69 & 0.65 & 1.68 & 1.84 & 1.63 & 1.21 \\
\hline & $(1.09)$ & $(0.92)$ & $(1.09)$ & $(1.09)$ & $(1.04)$ & $(0.96)$ & $(0.89)$ & $(1.28)$ & (1.10) & $(1.08)$ & $(1.31)$ & (1.41) & (1.36) & $(0.84)$ \\
\hline GDP growth & $\begin{array}{l}-0.46 \\
0.33)\end{array}$ & -0.14 & -0.21 & $=-0.47$ & $=-0.20$ & $=0.25$ & $\begin{array}{l}-0.26 \\
0.351 \\
0\end{array}$ & $\begin{array}{l}-0.26 \\
0.251\end{array}$ & $\begin{array}{l}-0.27 \\
0.231 \\
0.231\end{array}$ & -0.084 & $7: 0.037$ & 0.12 & 0.12 & $=-0.12$ \\
\hline Time fixed effects & YES & YES & YES & YES & YES & YES & YES & $\begin{array}{l}\text { (U. } \\
\text { YES }\end{array}$ & YES & YES & $\begin{array}{l}(0.20) \\
\text { YES }\end{array}$ & $\frac{(0.19)}{\text { YES }}$ & $\frac{(0.21)}{\text { YES }}$ & YES \\
\hline Country fixed effects & YES & YES & YES & YES & YES & YES & YES & YES & YES & YES & YES & YES & YES & YES \\
\hline Observatio & 178 & 329 & 280 & 179 & 293 & 320 & 320 & 304 & $\begin{array}{l}304 \\
0527\end{array}$ & 304 & 263 & 254 & 254 & 356 \\
\hline R squared & & & & 0.530 & 0.554 & 0.522 & 0.520 & 0.510 & & 0.526 & 0.555 & 0.563 & 0.549 & \\
\hline
\end{tabular}

Note: Dependent variable is the natural logarithm of redistribution. Standard errors are clustered at the country level. R squared does not incorporate the effect of country fixed effects. Significance levels: * $\mathrm{p}<.1 ; * * \mathrm{p}<.05 ; * * * \mathrm{p}<.01$, Bold highlights significant coefficients 
Table A.12. The effects of old-age pension systems and early retirement incentives on redistribution to the working-age population - controlling for GDP growth

\begin{tabular}{|c|c|c|c|c|c|c|c|c|c|c|c|c|c|}
\hline Dependent variable is $\ln$ (redistribution) & 1 & 2 & 3 & 4 & 5 & 6 & 7 & 8 & 9 & 10 & 11 & 12 & 13 \\
\hline \multicolumn{14}{|l|}{ Old-age pension parameters ( 1 ) } \\
\hline \multirow[t]{2}{*}{ Normal retirement age } & -0.013 & & & & & & & & & & & & \\
\hline & $(0.0084$ & & & & & & & & & & & & \\
\hline \multirow{2}{*}{ Normal retirement age, men } & & -0.0084 & & & & & & & & & & & \\
\hline & & $(0.0078)$ & & & & & & & & & & & \\
\hline \multirow[t]{2}{*}{ Normal retirement age, women } & & & $-0.013^{*}$ & & & & & & & & & & \\
\hline & & & $(0.0069)$ & & & & & & & & & & \\
\hline \multirow[t]{2}{*}{ Minimum retirement age } & & & & $0.012^{\star \star \star}$ & & & & & & & & & \\
\hline & & & & $(0.0034)$ & & & & & & & & & \\
\hline \multirow[t]{2}{*}{ Minimum retirement, men } & & & & & $0.014^{\star \star \star}$ & & $0.019^{* \star \star}$ & $0.015^{\star \star \star}$ & ${ }^{*} 0.017^{\star \star \star}$ & $\star 0.017^{\star \star \star}$ & $0.016^{\star \star *}$ & & \\
\hline & & & & & $(0.0024)$ & & $(0.0028)$ & $(0.0022)$ & $(0.0026)$ & ) $(0.0031)$ & $(0.0023)$ & & \\
\hline \multirow[t]{2}{*}{ Minimum retirement, women } & & & & & & $0.0093^{*}$ & & & & & & & \\
\hline & & & & & & $(0.0047)$ & & & & & & & \\
\hline \multirow[t]{2}{*}{ Replacement rate from the old-age pension system at age 60 (2) } & & & & & & & $0.077^{\star}$ & & & & & & \\
\hline & & & & & & & $"(0.039)$ & & & & & & \\
\hline \multirow[t]{2}{*}{ Replacement rate from the old-age pension system at age 65 (2) } & & & & & & & & $0.11^{\star \star}$ & & & & & \\
\hline & & & & & & & & $"(0.044)$ & & & & & \\
\hline \multirow[t]{2}{*}{ Replacement rate from the old-age pension system at age 69 (2) } & & & & & & & & & $0.42^{\star}$ & & & & \\
\hline & & & & & & & & & $(0.20)$ & & & & \\
\hline \multirow[t]{2}{*}{ Replacement rate from the old-age pension system between ages $60 \& 65$ (average) (2) } & & & & & & & & & & 0.041 & & & \\
\hline & & & & & & & & & & $(0.046)$ & & & \\
\hline \multirow[t]{2}{*}{ Replacement rate from the old-age pension system between ages 65 \& 69 (average) (2) } & & & & & & & & & & & $0.32^{*}$ & & \\
\hline & & & & & & & & & & & $(0.16)$ & & \\
\hline \multicolumn{14}{|l|}{ Effective retirement age } \\
\hline \multirow[t]{2}{*}{ Average effective retirement age, men } & & & & & & & & & & & & $-0.017^{\star}$ & \\
\hline & & & & & & & & & & & & "(0.0083) & \\
\hline \multirow{2}{*}{ Average effective retirement age, women } & & & & & & & & & & & & & -0.0012 \\
\hline & & & & & & & & & & & & & $(0.0079)$ \\
\hline \multicolumn{14}{|l|}{ Social spending (in $\%$ of GDP) } \\
\hline Social spending on old-age population & 1.85 & 1.97 & 1.78 & 1.81 & 1.58 & 1.99 & 1.50 & 1.61 & 1.11 & 1.49 & 1.50 & -2.34 & -2.33 \\
\hline & $(2.21)$ & $(2.28)$ & $(2.16)$ & $(1.91)$ & $(1.78)$ & $(2.03)$ & $(1.79)$ & $(1.78)$ & $(1.98)$ & $(1.84)$ & $(1.85)$ & $(2.94)$ & $(2.96)$ \\
\hline Total Social spending & $2.49^{\star}$ & 2.33 & $2.59^{\star}$ & $2.43^{*}$ & $2.50^{*}$ & $2.37^{\star}$ & $2.42^{\star}$ & $2.47^{\star}$ & $2.33^{\star \star}$ & $2.49^{*}$ & $2.36^{*}$ & $2.43^{* \star}$ & $2.44^{\star \star}$ \\
\hline & $(1.40)$ & $(1.40)$ & (1.40) & '(1.33) & "(1.32) & '(1.34) & (1.26) & (1.29) & $(1.07)$ & $(1.31)$ & $(1.16)$ & '(1.13) & $(1.17)$ \\
\hline Technological change \& Globalisation & & & & & & & & & & & & & \\
\hline Ln (openness) & $\begin{array}{l}0.17 \\
(0.14)\end{array}$ & 0.16 & 0.18 & $=0.17$ & 0.18 & 0.16 & 0.16 & 0.17 & 0.21 & 0.17 & 0.18 & $\begin{array}{l}\mathbf{0 . 2 2}^{\star \star} \\
(0.10)\end{array}$ & $\begin{array}{l}\mathbf{0 . 2 6 ^ { * }} \\
(0.13)\end{array}$ \\
\hline Ln (MFP change) & $\begin{array}{l}-0.22 \\
(0.13)\end{array}$ & $\begin{array}{l}-0.23 \\
(0.14)\end{array}$ & $\begin{array}{l}-0.19 \\
(0.13)\end{array}$ & -0.12 & $\begin{array}{l}-0.10 \\
(0.14)\end{array}$ & -0.13 & $=\begin{array}{l}-0.13 \\
(0.14)\end{array}$ & $\begin{array}{l}-0.13 \\
(0.13)\end{array}$ & $=$ & -0.11 & $\begin{array}{l}-0.12 \\
(0.13)\end{array}$ & $\begin{array}{r}-0.38^{*} \\
-(0.20)\end{array}$ & $\begin{array}{r}-0.42^{\star} \\
(0.22)\end{array}$ \\
\hline Labour market, sociodemographic conditions and earnings inequality & & & & & & & & & & & & & \\
\hline Share of 55-65 in working-age population & -0.92 & -0.92 & -0.92 & -1.11 & -1.14 & -1.06 & -0.83 & -1.24 & $-1.63^{\star}$ & -1.06 & -1.47 & 0.039 & 0.10 \\
\hline & "(1.09) & $(1.09)$ & (1.10) & "(1.04) & (1.02) & "(1.05) & "(1.08) & (1.02) & $(0.93)$ & $(1.07)$ & $(0.97)$ & $(1.09)$ & (1.16) \\
\hline Old-age dependency ratio & -0.53 & -0.53 & -0.60 & -1.11 & -1.19 & -1.02 & $=-1.15$ & -1.09 & -1.25 & -1.17 & -1.11 & -0.61 & -0.58 \\
\hline In (Unemployment rate) & $\begin{array}{l}(1.01) \\
0.033\end{array}$ & $\begin{array}{r}(1.05) \\
0.038\end{array}$ & $\begin{array}{r}(0.98) \\
0.029\end{array}$ & $\begin{array}{l}(0.95) \\
0.026\end{array}$ & $\begin{array}{l}(0.94) \\
0.024\end{array}$ & $\begin{array}{l}(0.95) \\
0.028\end{array}$ & $\begin{array}{l}(0.90) \\
0.029\end{array}$ & $\begin{array}{l}(0.93) \\
0.028\end{array}$ & $\begin{array}{l}(0.86) \\
0.030\end{array}$ & $\begin{array}{l}(0.95) \\
0.028\end{array}$ & $\begin{array}{l}(0.89) \\
0.030\end{array}$ & $\begin{array}{c}(0.67) \\
0.080^{*}\end{array}$ & $\begin{array}{l}(0.71) \\
0.082^{*}\end{array}$ \\
\hline & (0.040) & $(0.042)$ & ( $(0.039)$ & '(0.041) & $(0.040)$ & $(0.042)$ & $(0.040)$ & $(0.040)$ & '(0.038) & $(0.041)$ & $(0.038)$ & ( & ' $(0.044)$ \\
\hline Earnings inequality: $\ln (d 9 d 1)$ & $-0.45^{\star *}$ & $-0.44^{\star \star}$ & $-0.46^{* \star}$ & $-0.39^{\star}$ & $-0.42^{\star \star}$ & $-0.37^{\star}$ & $-0.42^{\star \star}$ & $-0.42^{\star \star}$ & $-0.45^{\star \star}$ & $-0.41^{\star \star}$ & $-0.44^{* \star}$ & $-0.59^{\star \star \star}$ & $-0.58^{\star \star}$ \\
\hline & $(0.18)$ & $"(0.18)$ & $(0.17)$ & '(0.19) & $"(0.19)$ & '(0.19) & $(0.19)$ & $(0.19)$ & ' $(0.20)$ & $(0.19)$ & $(0.20)$ & $(0.21)$ & $(0.22)$ \\
\hline Share of workless families with children among working-age households & 1.27 & 1.37 & 1.21 & $1.69^{*}$ & $1.67^{\star}$ & 1.67 & $1.71^{*}$ & 1.53 & 1.38 & $1.63^{*}$ & 1.41 & 1.12 & 1.44 \\
\hline & '(1.01) & $"(1.01)$ & $(1.00)$ & '(0.95) & $(0.92)$ & '(1.00) & " $(0.92)$ & (0.94) & $"(0.95)$ & $(0.93)$ & $(0.96)$ & $(0.97)$ & '(0.96) \\
\hline GDP growth & 0.12 & 0.14 & 0.10 & 0.11 & 0.082 & 0.13 & 0.11 & 0.084 & 0.011 & 0.078 & 0.055 & -0.28 & -0.18 \\
\hline & $(0.31)$ & $(0.32)$ & $(0.30)$ & $(0.31)$ & $(0.31)$ & $(0.32)$ & $(0.31)$ & $(0.31)$ & $(0.31)$ & ${ }^{\prime}(0.31)$ & $(0.31)$ & $(0.29)$ & ' $(0.24)$ \\
\hline Time fixed effects & YES & YES & YES & YES & YES & YES & YES & YES & YES & YES & YES & YES & YES \\
\hline Country fixed effects & YES & YES & YES & YES & YES & YES & YES & YES & YES & YES & YES & YES & YES \\
\hline Observations & 233 & 233 & 233 & 229 & 229 & 229 & 229 & 229 & 229 & 229 & 229 & 327 & 327 \\
\hline R squared & 0.649 & 0.645 & 0.652 & 0.657 & 0.661 & $0.652 \mid$ & 0.667 & 0.666 & 0.677 & 0.662 & 0.672 & 0.547 & 0.538 \\
\hline
\end{tabular}

Note: Dependent variable is the natural logarithm of redistribution. Standard errors are clustered at the country level. $\mathrm{R}$ squared does not incorporate the effect of country fixed effects. (1) Legal age conditions for someone who enters the labour market at age 25 and exclude minimum contribution period conditions. The idea is to use legal ages that are referred to in public as the typical retirement ages. (2) Men. Excluding any kind of benefit received from unemployment benefit schemes or disability pension schemes.

Significance levels: $* \mathrm{p}<.1 ; * * \mathrm{p}<.05 ; * * * \mathrm{p}<.01$

Bold highlights significant coefficients 
Table A.13. Redistribution: the effects of social spending and tax revenues - IV estimation

\begin{tabular}{|c|c|c|c|c|c|c|c|c|c|c|c|}
\hline Dependent variable is $\ln$ (redistribution) & 1 & 2 & 3 & 4 & 5 & 6 & 7 & 8 & 9 & 10 & 11 \\
\hline \multicolumn{12}{|l|}{ Social spending (in \% of GDP) } \\
\hline \multirow[t]{2}{*}{ Social spending on cash support to working-age population } & $3.89^{\star \star}$ & & & & & & 2.24 & & 1.41 & & 2.30 \\
\hline & $(1.76)$ & & & & & & $(1.61)$ & & $(1.54)$ & & $(1.62)$ \\
\hline \multirow{2}{*}{ Total Social spending on working-age population } & & 2.36 & & & & & & & & & \\
\hline & & $(1.44)$ & & & & & & & & & \\
\hline \multirow[t]{2}{*}{ Total Social spending on old-age population } & & -1.08 & & & & & & & & & \\
\hline & & $(3.03)$ & & & & & & & & & \\
\hline \multirow[t]{2}{*}{ Total Social spending } & & & 1.13 & & & & & 1.18 & & 0.66 & \\
\hline & & & $(1.31)$ & & & & & $(1.04)$ & & $(1.12)$ & \\
\hline \multicolumn{12}{|l|}{ Tax revenues (in\% of GDP) } \\
\hline \multirow[t]{2}{*}{ Tax revenues from PIT and employees' SSC } & & & & $4.96^{\star \star \star}$ & & & $4.17^{\star \star \star}$ & & $4.27^{\star \star \star}$ & & $4.11^{\star \star \star}$ \\
\hline & & & & $(1.28)$ & & & $(1.42)$ & & $(1.20)$ & & $(1.38)$ \\
\hline \multirow[t]{2}{*}{ Tax revenues from $\mathrm{PIT}$} & & & & & $5.43^{\star \star \star}$ & & & & & & \\
\hline & & & & & $(1.39)$ & & & & & & \\
\hline \multirow{2}{*}{ Tax revenues from employees' SSC } & & & & & 2.27 & & & & & & \\
\hline & & & & & $(1.59)$ & & & & & & \\
\hline \multirow[t]{2}{*}{ Total Tax revenues } & & & & & & 0.34 & & -0.11 & & -0.18 & \\
\hline & & & & & & $(1.87)$ & & $(1.87)$ & & "(1.86) & \\
\hline \multicolumn{12}{|l|}{ Interaction between openness and $\left(^{\star}\right)$ : } \\
\hline \multirow[t]{2}{*}{ Tax revenues from PIT and employees' SSC } & & & & & & & & & $-3.77^{\star \star \star}$ & & \\
\hline & & & & & & & & & $(0.96)$ & & \\
\hline \multirow{2}{*}{ Total tax revenues } & & & & & & & & & & $-1.90^{\star \star}$ & \\
\hline & & & & & & & & & & $(0.84)$ & \\
\hline \multirow[t]{2}{*}{ Social spending on cash support to working-age population } & & & & & & & & & & & -0.62 \\
\hline & & & & & & & & & & & $(1.31)$ \\
\hline \multicolumn{12}{|l|}{ Technological change \& Globalisation } \\
\hline \multirow[t]{2}{*}{ Ln (openness) } & $0.23^{\star \star \star}$ & $0.26^{\star \star}$ & $0.22^{\star \star \star}$ & 0.064 & 0.059 & 0.22 & 0.068 & 0.22 & 0.053 & 0.20 & 0.064 \\
\hline & $(0.072)$ & $(0.10)$ & $(0.082)$ & $(0.053)$ & $(0.054)$ & $(0.16)$ & $(0.062)$ & $(0.16)$ & $(0.056)$ & $(0.16)$ & $(0.060)$ \\
\hline \multirow[t]{2}{*}{ Ln (MFP change) } & $-0.44^{\star \star *}$ & $-0.50^{\star \star}$ & $-0.39^{\star *}$ & $-0.27^{\star \star}$ & $-0.23^{*}$ & -0.48 & $-0.26^{\star}$ & -0.40 & $-0.31^{* *}$ & -0.44 & $-0.25^{\star}$ \\
\hline & $(0.15)$ & $(0.23)$ & $(0.18)$ & $"(0.14)$ & $(0.13)$ & ${ }^{\prime}(0.30)$ & $(0.15)$ & $(0.30)$ & $(0.13)$ & $(0.29)$ & $(0.15)$ \\
\hline \multicolumn{12}{|l|}{ Labour market, sociodemographic conditions and earnings inequality } \\
\hline \multirow[t]{2}{*}{ In(Unemployment rate) } & $0.098^{\star \star \star}$ & $0.12^{\star \star \star}$ & $0.13^{\star \star}$ & $0.14^{\star \star \star}$ & $0.15^{\star * *}$ & $0.16^{\star \star \star}$ & $0.098^{\star * \star}$ & $0.13^{\star \star \star}$ & $0.12^{\star \star \star}$ & $0.15^{\star \star *}$ & $0.098^{\star \star \star}$ \\
\hline & $(0.037)$ & $(0.044)$ & (0.053) & $"(0.022)$ & '(0.022) & $(0.023)$ & $(0.036)$ & "(0.038) & $(0.036)$ & $(0.041)$ & $(0.036)$ \\
\hline \multirow[t]{2}{*}{ Earnings inequality: In (d9d1) } & $-0.52^{\star \star \star}$ & $-0.62^{\star \star *}$ & $-0.45^{\star * *}$ & $-0.33^{\star *}$ & $-0.33^{\star *}$ & $-0.46^{* *}$ & $-0.38^{\star *}$ & $-0.45^{\star \star}$ & -0.24 & $-0.42^{\star *}$ & $-0.37^{\star *}$ \\
\hline & $(0.17)$ & $(0.22)$ & $(0.16)$ & $(0.14)$ & $(0.14)$ & $(0.18)$ & $(0.16)$ & $(0.19)$ & $(0.17)$ & $(0.18)$ & $(0.16)$ \\
\hline Share of workless families with children among working-age households & $\begin{array}{c}0.72 \\
(0.77)\end{array}$ & $\begin{array}{c}0.91 \\
(0.78) \\
\end{array}$ & $\begin{array}{c}0.60 \\
(0.84) \\
\end{array}$ & $\begin{array}{l}0.48 \\
(0.78)\end{array}$ & $\begin{array}{l}0.45 \\
(0.77) \\
\end{array}$ & $\begin{array}{c}0.65 \\
(0.84)\end{array}$ & $\begin{array}{c}0.82 \\
(0.68) \\
\end{array}$ & $\begin{array}{l}0.60 \\
(0.87)\end{array}$ & $\begin{array}{l}1.23^{*} \\
(0.70) \\
\end{array}$ & $\begin{array}{l}0.57 \\
(0.91)\end{array}$ & $\begin{array}{c}0.94 \\
(0.80)\end{array}$ \\
\hline Time fixed effects & Yes & Yes & Yes & Yes & Yes & Yes & Yes & Yes & Yes & Yes & Yes \\
\hline Country fixed effects & Yes & Yes & Yes & Yes & Yes & Yes & Yes & Yes & Yes & Yes & Yes \\
\hline Observations & 323 & 323 & 350 & 339 & 339 & 352 & 313 & 350 & 313 & 350 & 313 \\
\hline Difference in Sargan test & 0.00 & 0.81 & 0.04 & 4.40 & 6.27 & 0.06 & 4.45 & 0.08 & 6.48 & 2.35 & 4.28 \\
\hline Degree of freedom & 1 & 2 & 1 & 1 & 2 & 1 & 2 & 2 & 3 & 3 & 3 \\
\hline$p$-value & 0.94 & 0.67 & 0.84 & 0.04 & 0.04 & 0.81 & 0.11 & 0.96 & 0.09 & 0.50 & 0.23 \\
\hline KP Under identification test & 9.18 & 11.20 & 12.10 & 13.30 & 13.90 & 17.90 & 12.70 & 18.80 & 15.70 & 19.00 & 11.80 \\
\hline Degree of freedom & 1 & 1 & 1 & 1 & 1 & 1 & 1 & 1 & 1 & 1 & 1 \\
\hline$p$-value & 0.00 & 0.00 & 0.00 & 0.00 & 0.00 & 0.00 & 0.00 & 0.00 & 0.00 & 0.00 & 0.00 \\
\hline
\end{tabular}

Note: Dependent variable is the natural logarithm of redistribution. Standard errors are clustered at the country level. $(*)$ Every variable in the interactions is demeaned. All policy variables are instrumented by their first lags.

Significance levels: $* \mathrm{p}<.1 ; * * \mathrm{p}<.05 ; * * * \mathrm{p}<.01$

Bold highlights significant coefficients 
Table A.14. Taxes and redistribution: a focus on the overall progressivity of personal income taxes on wage earnings - IV estimation

\begin{tabular}{|c|c|c|c|c|c|c|c|c|c|c|c|c|c|c|c|c|c|}
\hline \begin{tabular}{|l} 
Dependent variable is In(redistribution) \\
Tax parameters \\
Progressivity of personal income taxes (1) \\
Overall structural progression of personal income taxes on wage earnings
\end{tabular} & $\begin{aligned} 0.23 \\
(0.25)\end{aligned}$ & $-\frac{0.21}{(0.22)}$ & $\begin{array}{l}0.20 \\
(0.19)\end{array}$ & $\begin{array}{l}0.20 \\
(0.19)\end{array}$ & 5 & 6 & 7 & 8 & 9 & 10 & 11 & 12 & 13 & 14 & 15 & 16 & 17 \\
\hline $\begin{array}{l}\text { Average effective tax rates across the distribution (1) } \\
\text { Average effective tax rate at } 6 \% \% \text { of the AW }\end{array}$ & & .02 & & $=-0.39$ & $\begin{array}{lllll} & \end{array}$ & 0.14 & 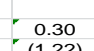 & 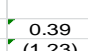 & 0.48 & (61.02) & (1) & 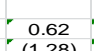 & 0.66 & . & (1.131) & (1.31) & 年 15 \\
\hline Average effective tax rate at $100 \%$ the $\mathrm{AW}$ & & (1.58) & $: \begin{array}{l}1.70 \\
(1.56)\end{array}$ & $\begin{array}{l}(1.38) \\
2.05^{* *} \\
(0.85)\end{array}$ & $\begin{array}{l}(1.26) \\
2.11 * * \\
(0.89)\end{array}$ & (1.1. & (1.22) & & (1.25) & & & & (1.29) & (1.30) & (1.31) & (1.31) & (1.32) \\
\hline Average effective tax rate at $133 \%$ of the $\mathrm{AW}$ & & & & & & $\begin{aligned} & 1.40^{*} \\
&(0.83)\end{aligned}$ & & & & & & & & & & & \\
\hline Average effective tax rate at $167 \%$ of the $A W$ & & & & & & & $\begin{array}{l}1.27^{*} \\
(0.74)\end{array}$ & & & & & & & & & & \\
\hline Average effective tax rate at $200 \%$ of the $\mathrm{AW}$ & & & & & & & $(0.14)$ & $1.33^{*}$ & & & & & & & & & \\
\hline Average effective tax rate at $233 \%$ of the $\mathrm{AW}$ & & & & & & & & (0.76) & $1.25^{*}$ & & & & & & & & \\
\hline Average effective tax rate at $267 \%$ of the $\mathrm{AW}$ & & & & & & & & & (0.75) & 1.19 & & & & & & & \\
\hline Average effective tax rate at $300 \%$ of the $\mathrm{AW}$ & & & & & & & & & & & $1.24^{\star}$ & & & & & & \\
\hline Average effective tax rate at $333 \%$ of the $A W$ & & & & & & & & & & & (0.73) & $1.21^{\star}$ & & & & & \\
\hline Average effective tax rate at $367 \%$ of the $\mathrm{AW}$ & & & & & & & & & & & & (0.69) & $1.16^{*}$ & & & & \\
\hline Average effective tax rate at $400 \%$ of the $\mathrm{AW}$ & & & & & & & & & & & & & $(0.68)$ & & & & \\
\hline Average effective tax rate at $433 \%$ of the $A W$ & & & & & & & & & & & & & & $(0.68)$ & & & \\
\hline Average effective tax rate at $467 \%$ of the $A W$ & & & & & & & & & & & & & & & $(0.68)$ & & \\
\hline Average enective tax rate at $46, \%$ or the AVV & & & & & & & & & & & & & & & & $(0.69)$ & \\
\hline Average effective tax rate at $500 \%$ of the $\mathrm{AW}$ & & & & & & & & & & & & & & & & & $1.19^{*}$ \\
\hline $\begin{array}{l}\text { Tax revenues } \\
\text { Total Tax revenues (\% of GDP) }\end{array}$ & $=-0.97$ & {$\left[\begin{array}{rl}-0.83 \\
(2.11)\end{array}\right.$} & {$\left[\begin{array}{l}-0.80 \\
(2.08)\end{array}\right.$} & {$\left[\begin{array}{ll}-0.81 \\
(2.05)\end{array}\right.$} & {$\left[\begin{array}{ll}-0.73 \\
(1.81)\end{array}\right.$} & $=-0.87$ & $=(1.83)$ & $\cdot(1.82)$ & {$\left[\begin{array}{l}-0.82 \\
(1.82)\end{array}\right.$} & $=\left(\begin{array}{l}-0.75 \\
(1.79)\end{array}\right.$ & $=$ & $=(1.81)$ & {$\left[\begin{array}{ll}-0.80 \\
(1.81)\end{array}\right.$} & {$\left[\begin{array}{ll}-0.81 \\
(1.81)\end{array}\right.$} & $=\frac{-0.82}{(1.81)}$ & $=-0.84$ & {$\left[\begin{array}{ll}-0.86 \\
(1.81)\end{array}\right.$} \\
\hline $\begin{array}{l}\text { Technological change \& Globalisati } \\
\text { Ln (openness) } \\
\text { Ln (MFP change) }\end{array}$ & 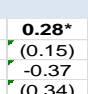 & 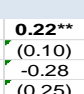 & $\begin{array}{l}0.18^{*} \\
:(0.099) \\
(-0.31 \\
-0.39)\end{array}$ & 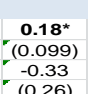 & 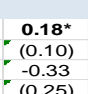 & 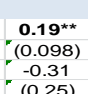 & 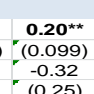 & 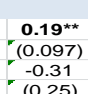 & 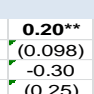 & 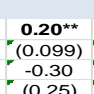 & $\begin{array}{l}\mathbf{0 . 1 9} \mathbf{9}^{\star *} \\
(0.097) \\
0.0 .29 \\
0.255\end{array}$ & $\begin{array}{l}\mathbf{0 . 1 9} \mathbf{9}^{\star *} \\
(0.096) \\
-0.28 \\
0.255\end{array}$ & 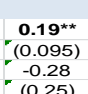 & \begin{tabular}{l}
$\mathbf{0 . 1 9 * *}$ \\
$(0.095)$ \\
\hdashline-0.28 \\
$0-0.255$
\end{tabular} & 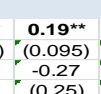 & 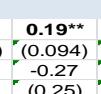 & $\begin{array}{l}\mathbf{0 . 1 9 * *} \\
:(0.093) \\
-0.027 \\
0.025\end{array}$ \\
\hline Labour market, sociodemographic conditions and earnings inequality & & & & & & & & & & & & & & & & & \\
\hline In(Unemployment rate) & (0.030) & $\begin{array}{ll}0.16 \\
(0.030) \\
(0.030)\end{array}$ & $(0.032)$ & 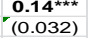 & $\begin{array}{ll}0.14+* t \\
(0.032)\end{array}$ & $\begin{array}{l}0.15^{\star \star \star x} \\
(0.031)\end{array}$ & $\left(\begin{array}{ll}0.15^{\star \star * *} \\
(0.032)\end{array}\right.$ & $\begin{array}{ll}\mathbf{0} .14+* *+ \\
(0.032)\end{array}$ & $\begin{array}{l}0.14 * \star * \\
(0.032)\end{array}$ & $\begin{array}{ll}0.14 \times \star x \\
(0.032)\end{array}$ & 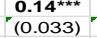 & $\begin{array}{l}0.14 \times * t \\
(0.033)\end{array}$ & $\begin{array}{l}0.14 * \star * \\
(0.033)\end{array}$ & 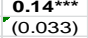 & 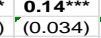 & & $\begin{array}{l}0.13+* t \\
(0.036)\end{array}$ \\
\hline Earnings inequality: In (d9d1) & $-0.49^{* *}$ & $-0.46^{*+}$ & $-0.54^{\star \star}$ & $-0.56^{\text {tot }}$ & $-0.56^{* *+*}$ & $-0.52^{* \star \star \star}$ & ${ }^{*}-0.51^{\star \star \star \star}$ & $(-0.51+2 \times+x$ & $-0.50^{* \star \star *}$ & $-0.50^{\star \star \star}$ & $-0.49^{\star \star \star}$ & $-0.50^{\star \star \star}$ & $-0.49^{* \star \star *}$ & - $-0.49^{*+*}$ & * $-0.49^{\star \star \star \star}$ & 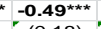 & $-0.49^{\star \star \star \star}$ \\
\hline Share of workless families with children among working-age households & $1.86^{*}$ & $1.93^{*}$ & $1.92^{*+*}$ & $1.91^{* t}$ & $1.90^{* \star}$ & $1.81^{\star \star}$ & $1.67^{\star}$ & $1.47^{\star}$ & 1.37 & 1.32 & $=1.26$ & 1.30 & $=0.1 .26$ & $=1.23$ & 1.18 & 1.14 & $\begin{array}{l}(0.18) \\
1.11\end{array}$ \\
\hline & $(1.05)$ & & $(0 .)^{2}$ & $(0.93)$ & $(0$. & $(0.8)$ & $(0$. & $(0.87)$ & $(0,0)$ & $(0.88)$ & $(0.89)$ & $(0.88)$ & & & & $(0.93)$ & F(0.93) \\
\hline $\begin{array}{l}\text { Time fixed effects } \\
\text { Country fixed effects }\end{array}$ & $\begin{array}{l}\text { YYes } \\
\text { Yes }\end{array}$ & $\begin{array}{l}\text { Yes } \\
\text { Yes }\end{array}$ & Yes & $\begin{array}{l}\text { Yes } \\
\text { Yes }\end{array}$ & $\begin{array}{l}\text { Yes } \\
\text { Yes }\end{array}$ & $\begin{array}{l}\text { YYs } \\
\text { Yes }\end{array}$ & $\begin{array}{l}\text { YYes } \\
\text { Yes }\end{array}$ & $\begin{array}{l}\text { Yes } \\
\text { Yes }\end{array}$ & $\begin{array}{l}\text { Yes } \\
\text { Yes }\end{array}$ & $\begin{array}{l}\text { YYes } \\
\text { Yes }\end{array}$ & $\begin{array}{l}\text { Yes } \\
\text { Yes }\end{array}$ & $\begin{array}{l}\text { YYes } \\
\text { Yes }\end{array}$ & Yes & $\begin{array}{l}\text { Yes } \\
\text { Yes }\end{array}$ & $\begin{array}{l}\text { Yes } \\
\text { Yes }\end{array}$ & $\begin{array}{l}\text { Yes } \\
\text { Yes }\end{array}$ & $\begin{array}{l}\text { YYes } \\
\text { Yes }\end{array}$ \\
\hline Observa & 302 & 302 & 302 & 302 & 307 & 307 & 307 & 307 & 307 & 307 & $\begin{array}{l}\text { res } \\
307\end{array}$ & $\begin{array}{l}\text { res } \\
307\end{array}$ & (100) & 307 & 307 & 307 & 307 \\
\hline Difference in Sargan test & & 1.96 & 1.33 3 & 4.43 & 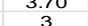 & 1.34 3 & 1.31 & 1.32 & 1.33 & 1.45 & 1.74 & 1.76 & 1.94 & 2.08 & 2.30 & 2.59 & 2.85 \\
\hline $\begin{array}{l}\text { Degree of freedom } \\
\text { p-value }\end{array}$ & 0.46 & 0.58 & 0.71 & 0.35 & 0.30 & 0.72 & 0.73 & 0.73 & 0.72 & $\begin{array}{l}3 \\
0.69\end{array}$ & $\begin{array}{l}3 \\
0.63\end{array}$ & $\begin{array}{l}3 \\
0.62\end{array}$ & $\begin{array}{l}3 \\
0.59\end{array}$ & 0.56 & $\begin{array}{l}3 \\
0.51\end{array}$ & $\begin{array}{l}3 \\
0.46\end{array}$ & $\begin{array}{l}3 \\
0.41\end{array}$ \\
\hline $\begin{array}{l}\text { KP Under identification test } \\
\text { Degree of freedom }\end{array}$ & $\begin{array}{c}13.20 \\
1\end{array}$ & $\begin{array}{c}11.90 \\
1\end{array}$ & $\begin{array}{c}12.00 \\
1\end{array}$ & $\begin{array}{c}11.90 \\
1\end{array}$ & $\begin{array}{c}13.70 \\
1\end{array}$ & $\begin{array}{c}12.70 \\
1\end{array}$ & $\begin{array}{c}12.90 \\
1\end{array}$ & $\begin{array}{c}12.70 \\
1\end{array}$ & $\begin{array}{c}12.90 \\
1\end{array}$ & $\begin{array}{c}13.30 \\
1\end{array}$ & $\begin{array}{c}13.20 \\
1\end{array}$ & $\begin{array}{c}13.10 \\
1\end{array}$ & $\begin{array}{c}13.10 \\
1\end{array}$ & $\begin{array}{c}12.90 \\
1\end{array}$ & $\begin{array}{c}12.80 \\
1\end{array}$ & $\begin{array}{c}12.60 \\
1\end{array}$ & $\begin{array}{c}12.50 \\
1\end{array}$ \\
\hline$p$-value & & & 0.00 & 0.00 & 0.00 & & 0.00 & & 0.00 & 0.00 & & & & & & & \\
\hline
\end{tabular}

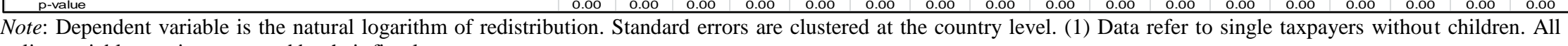
policy variables are instrumented by their first lags.

Significance levels: $* \mathrm{p}<.1 ; * * \mathrm{p}<.05 ; * * * \mathrm{p}<.01$, Bold highlights significant coefficients 
Table A.15. Taxes and redistribution: a focus on top tax rates and on the taxation of capital income IV estimation

\begin{tabular}{|c|c|c|c|c|c|c|c|c|c|}
\hline Dependent variable is $\ln$ (redistribution) & 1 & 2 & 3 & 4 & 5 & 6 & 7 & 8 & 9 \\
\hline Tax parameters & & & & & & & & & \\
\hline \multicolumn{10}{|l|}{ Top tax rates } \\
\hline \multirow{2}{*}{ Top statutory personal income tax rates } & $1.05^{\star \star}$ & $0.94^{\star \star}$ & & & & & & & \\
\hline & $(0.48)$ & $(0.42)$ & & & & & & & \\
\hline \multirow{2}{*}{ Top marginal tax rates - $\mathrm{PIT}$} & & & 0.67 & & & & & & \\
\hline & & & $(0.44)$ & & & & & & \\
\hline \multirow[t]{2}{*}{ Top marginal tax rates - PIT \& employee SSC } & & & & $0.69^{* \star}$ & $0.66^{*}$ & & & & \\
\hline & & & & $(0.33)$ & $(0.34)$ & & & & \\
\hline \multicolumn{10}{|l|}{ Taxation of capital income } \\
\hline \multirow{2}{*}{ Net personal tax on dividend income } & & & & & & $0.42^{\star}$ & $0.42^{\star}$ & & \\
\hline & & & & & & $(0.23)$ & $(0.23)$ & & \\
\hline \multirow[t]{2}{*}{ Share of overall tax rate on dividend income collected through the use of PIT } & & & & & & & & 0.21 & 0.22 \\
\hline & & & & & & & & $(0.14)$ & $(0.15)$ \\
\hline \multicolumn{10}{|l|}{ Average effective tax rates controls(1) } \\
\hline \multirow[t]{2}{*}{ Average effective tax rate at $67 \%$ of the AW } & & 0.12 & & & 0.67 & & -0.24 & & -0.35 \\
\hline & & $(1.24)$ & & & (1.52) & & $(1.26)$ & & "(1.30) \\
\hline \multirow[t]{2}{*}{ Average effective tax rate at $100 \%$ the $\mathrm{AW}$} & & 1.08 & & & 0.58 & & $1.79^{\star \star}$ & & $1.97^{\star \star}$ \\
\hline & & $(0.77)$ & & & $(1.00)$ & & $(0.79)$ & & $(0.89)$ \\
\hline \multicolumn{10}{|l|}{ Tax revenues } \\
\hline \multirow[t]{2}{*}{ Total Tax revenues (\% of GDP) } & -1.07 & -0.89 & -1.19 & -0.76 & -0.59 & -0.74 & -0.60 & -0.76 & -0.61 \\
\hline & $(1.81)$ & $(1.60)$ & $(2.06)$ & (1.89) & $(1.62)$ & $(2.01)$ & $(1.68)$ & $(2.08)$ & $(1.73)$ \\
\hline \multicolumn{10}{|l|}{ Technological change \& Globalisation } \\
\hline \multirow[t]{2}{*}{ Ln (openness) } & $0.26^{\star \star}$ & $0.19^{\star \star}$ & $0.26^{\star}$ & $0.26^{\star}$ & $0.19^{\star \star}$ & $0.25^{\star}$ & 0.16 & $0.25^{\star}$ & 0.16 \\
\hline & $(0.13)$ & $(0.088)$ & $(0.13)$ & $(0.14)$ & $(0.098)$ & $(0.15)$ & $(0.099)$ & $(0.15)$ & $(0.100)$ \\
\hline \multirow[t]{2}{*}{ Ln (MFP change) } & -0.27 & -0.24 & -0.32 & -0.42 & -0.34 & -0.24 & -0.21 & -0.25 & -0.22 \\
\hline & $(0.29)$ & $(0.25)$ & $(0.32)$ & $(0.34)$ & $(0.28)$ & $(0.27)$ & $(0.20)$ & $(0.29)$ & $(0.21)$ \\
\hline \multicolumn{10}{|l|}{ Labour market, sociodemographic conditions and earnings inequality } \\
\hline \multirow[t]{2}{*}{ In(Unemployment rate) } & $0.12^{\star \star \star}$ & $0.12^{\star \star \star}$ & $0.13^{\star \star \star}$ & $0.14^{\star \star \star}$ & $0.13^{\star \star \star}$ & $0.17^{\star \star \star}$ & $0.15^{\star \star \star}$ & $0.17^{\star \star \star}$ & $0.15^{\star \star \star}$ \\
\hline & $(0.040)$ & $(0.037)$ & "(0.041) & $(0.033)$ & $(0.029)$ & $(0.027)$ & $(0.027)$ & $(0.027)$ & $(0.029)$ \\
\hline \multirow[t]{2}{*}{ Earnings inequality: $\ln (\mathrm{d} 9 \mathrm{~d} 1)$} & $-0.46^{\star \star *}$ & $-0.48^{\star \star *}$ & $-0.59^{* \star}$ & $-0.56^{\star \star \star}$ & $-0.55^{\star \star \star}$ & $-0.44^{\star \star}$ & $-0.50^{\star \star \star}$ & $-0.40^{\star \star}$ & $-0.46^{\star \star}$ \\
\hline & $(0.17)$ & $(0.16)$ & $(0.24)$ & $(0.21)$ & $(0.19)$ & $(0.18)$ & $(0.18)$ & $(0.20)$ & $(0.20)$ \\
\hline \multirow[t]{2}{*}{ Share of workless families with children among working-age households } & 0.57 & 0.70 & 1.04 & 0.80 & 0.87 & 1.49 & $1.51^{*}$ & $1.75^{\star}$ & $1.78^{\star}$ \\
\hline & $(0.97)$ & $(0.89)$ & $(0.99)$ & $(0.85)$ & $(0.81)$ & $(0.97)$ & $(0.89)$ & $(1.02)$ & $(0.93)$ \\
\hline Time fixed effects & Yes & Yes & Yes & Yes & Yes & Yes & Yes & Yes & Yes \\
\hline Country fixed effects & Yes & Yes & Yes & Yes & Yes & Yes & Yes & Yes & Yes \\
\hline Observations & 312 & 307 & 312 & 312 & 307 & 312 & 307 & 312 & 307 \\
\hline Difference in Sargan test & 2.67 & 9.44 & 3.41 & 4.91 & 8.98 & 0.40 & 4.42 & 0.44 & 5.24 \\
\hline Degree of freedom & 2 & 4 & 2 & 2 & 4 & 2 & 4 & 2 & 4 \\
\hline $\mathrm{p}$-value & 0.26 & 0.05 & 0.18 & 0.09 & 0.06 & 0.82 & 0.35 & 0.80 & 0.26 \\
\hline KP Under identification test & 12.90 & 11.80 & 11.00 & 14.00 & 13.00 & 15.80 & 14.00 & 15.90 & 14.50 \\
\hline Degree of freedom & 1 & 1 & 1 & 1 & 1 & 1 & 1 & 1 & 1 \\
\hline $\mathrm{p}$-value & 0.00 & 0.00 & 0.00 & 0.00 & 0.00 & 0.00 & 0.00 & 0.00 & 0.00 \\
\hline
\end{tabular}

Note: Dependent variable is the natural logarithm of redistribution. Standard errors are clustered at the country level. (1) Data refer to single taxpayers without children. All policy variables are instrumented by their first lags.

Significance levels: $* \mathrm{p}<.1 ; * * \mathrm{p}<.05 ; * * * \mathrm{p}<.01$

Bold highlights significant coefficients 
Table A.16. The tax structure and income redistribution - IV estimation

\begin{tabular}{|c|c|c|c|c|c|c|}
\hline \multirow{2}{*}{\multicolumn{7}{|c|}{$\begin{array}{l}\text { Dependent variable is } \ln (\text { redistribution) } \\
\text { Tax structure (\% of Total Tax revenue) }\end{array}$}} \\
\hline & & & & & & \\
\hline \multirow[t]{2}{*}{ Tax revenue share from PIT and employees' SSC } & $1.46^{\star \star}$ & & & & & \\
\hline & $(0.65)$ & & & & & \\
\hline \multirow[t]{2}{*}{ From PIT } & & $1.65^{\star \star}$ & & & & \\
\hline & & $(0.79)$ & & & & \\
\hline \multirow[t]{2}{*}{ From employees' SSC } & & 0.88 & & & & \\
\hline & & $(0.68)$ & & & & \\
\hline \multirow[t]{2}{*}{ Tax revenue share from goods and services } & & & $-3.28^{\star \star \star}$ & $-3.25^{\star \star \star}$ & & \\
\hline & & & $(0.68)$ & $(0.62)$ & & \\
\hline \multirow[t]{2}{*}{ From production, sale transfer } & & & & & $-2.76^{\star \star \star}$ & $-2.75^{\star \star \star}$ \\
\hline & & & & & $(0.64)$ & $(0.64)$ \\
\hline \multirow[t]{2}{*}{ From use of goods and perform } & & & & & $-7.15^{\star \star \star}$ & * -7.26 *** \\
\hline & & & & & $(2.36)$ & $(2.40)$ \\
\hline \multirow[t]{2}{*}{ Tax revenue share from property } & & & 0.86 & & & -0.33 \\
\hline & & & $(1.72)$ & & & $(1.41)$ \\
\hline \multirow[t]{2}{*}{ From Recurrent taxes on immovable property } & & & & 1.68 & & \\
\hline & & & & $(1.77)$ & & \\
\hline \multirow[t]{2}{*}{ From Recurrent taxes on net wealth } & & & & 3.45 & & \\
\hline & & & & $(4.88)$ & & \\
\hline \multirow[t]{2}{*}{ From Estate, inheritance and gift taxes } & & & & -3.45 & & \\
\hline & & & & $(7.05)$ & & \\
\hline \multirow[t]{2}{*}{ From taxes on financial and capital transactions } & & & & -2.77 & & \\
\hline & & & & $(2.70)$ & & \\
\hline \multirow[t]{2}{*}{ From Non-recurrent taxes on property } & & & & 6.33 & & \\
\hline & & & & $(4.20)$ & & \\
\hline \multicolumn{7}{|l|}{ Tax revenues (\% of GDP) } \\
\hline \multirow[t]{2}{*}{ Total Tax revenues } & $2.51^{\star \star \star}$ & $2.41^{\star \star *}$ & -0.11 & 0.061 & 0.020 & 0.035 \\
\hline & $(0.68)$ & $(0.69)$ & $(1.16)$ & $(1.20)$ & $(0.90)$ & $(0.92)$ \\
\hline \multicolumn{7}{|l|}{ Technological change \& Globalisation } \\
\hline \multirow[t]{2}{*}{ Ln (openness) } & 0.028 & 0.030 & $0.29^{\star \star}$ & $0.26^{\star \star \star}$ & $0.24^{\star \star \star}$ & $0.24^{\star \star \star}$ \\
\hline & $(0.068)$ & $(0.070)$ & $(0.11)$ & $(0.085)$ & $(0.073)$ & $(0.087)$ \\
\hline \multirow[t]{2}{*}{ Ln (MFP change) } & -0.16 & -0.13 & $-0.69^{\star \star \star}$ & $-0.64^{\star \star}$ & $-0.61^{* \star *}$ & $-0.61^{\star * *}$ \\
\hline & $(0.17)$ & $(0.16)$ & $(0.26)$ & $(0.26)$ & $(0.22)$ & $(0.22)$ \\
\hline \multicolumn{7}{|l|}{ Labour market, sociodemographic conditions and earnings inequality } \\
\hline \multirow[t]{2}{*}{ In(Unemployment rate) } & $0.14^{\star \star \star}$ & $0.15^{\star \star \star}$ & ${ }^{\star} 0.14^{\star \star \star}$ & $0.11^{\star \star \star}$ & $0.14^{\star \star \star}$ & $0.14^{\star \star \star}$ \\
\hline & "(0.024) & $(0.023)$ & $(0.029)$ & $(0.037)$ & $(0.030)$ & $(0.030)$ \\
\hline \multirow[t]{2}{*}{ Earnings inequality: $\ln (\mathrm{d} 9 \mathrm{~d} 1)$} & $-0.28^{\star \star}$ & $-0.29^{\star *}$ & $-0.58^{\star \star \star}$ & $-0.57^{\star \star \star}$ & $-0.61^{\star \star *}$ & $-0.61^{\star \star \star}$ \\
\hline & $(0.14)$ & $(0.14)$ & $(0.16)$ & $(0.17)$ & $(0.16)$ & $(0.17)$ \\
\hline Share of workless families with children among working-age households & 0.54 & 0.48 & -0.47 & -0.76 & -0.088 & -0.092 \\
\hline & $(0.89)$ & $(0.93)$ & $(0.82)$ & $(0.74)$ & $(0.91)$ & $(0.90)$ \\
\hline Time fixed effects & Yes & Yes & Yes & Yes & Yes & Yes \\
\hline Country fixed effects & Yes & Yes & Yes & Yes & Yes & Yes \\
\hline Observations & 339 & 339 & 352 & 352 & 352 & 352 \\
\hline Difference in Sargan test & 7.58 & 9.11 & 12.70 & 16.20 & 10.70 & 10.70 \\
\hline Degree of freedom & 2 & 3 & 3 & 7 & 3 & 4 \\
\hline $\mathrm{p}$-value & 0.02 & 0.03 & 0.01 & 0.02 & 0.01 & 0.03 \\
\hline KP Under identification test & 17.70 & 15.80 & 14.50 & 11.00 & 12.60 & 13.10 \\
\hline Degree of freedom & 1 & 1 & 1 & 1 & 1 & 1 \\
\hline p-value & 0.00 & 0.00 & 0.00 & 0.00 & 0.00 & 0.00 \\
\hline
\end{tabular}

Note: Dependent variable is the natural logarithm of redistribution. Standard errors are clustered at the country level. All policy variables are instrumented by their first lags.

Significance levels: $* \mathrm{p}<.1 ; * * \mathrm{p}<.05 ; * * * \mathrm{p}<.01$

Bold highlights significant coefficients 
Table A.17. Transfers and redistribution: a focus on unemployment-related transfers - IV estimation

\begin{tabular}{|c|c|c|c|c|c|c|c|c|c|c|c|c|c|c|}
\hline $\begin{array}{l}\text { Dependent variable is In(redistribution) } \\
\text { Transfer parameters }\end{array}$ & 1 & 2 & 3 & 4 & 5 & 6 & 7 & 8 & 9 & 10 & 11 & $\overline{12}$ & 13 & 14 \\
\hline \multicolumn{15}{|l|}{ Net unemployment benefit replacement rate (1) } \\
\hline Over 5 years - at $100 \%$ of the AW, married couple & $0.90^{\star *}$ & & & & & & & 0.29 & & & 0.49 & & & \\
\hline Over 5 years - at $150 \%$ of the AW, married couple & & 0.79 & & & & & & & & & & & & \\
\hline Over 5 years - at $67 \%$ of the $A W$, married couple & & & $0.71^{* *}$ & & & & & & 0.30 & & & 0.31 & & \\
\hline & & & $(0.33)$ & & & & & & "(0.32) & & & $"(0.25)$ & & \\
\hline Initial - at $100 \%$ of the AW, married couple & & & & 0.66 & & & & & & & & & & \\
\hline & & & & $(0.42)$ & & & & & & & & & & \\
\hline Initial - at $67 \%$ of the AW, married couple & & & & & 0.16 & & & & & & & & & \\
\hline Long-term- at $100 \%$ of the AW, married couple & & & & & (0.34) & $0.84^{\star *}$ & & & & & & & & \\
\hline & & & & & & $(0.38)$ & & & & & & & & \\
\hline Long-term-at $67 \%$ of the $\mathrm{AW}$, married couple & & & & & & & $0.70^{\star \star}$ & & & 0.30 & & & 0.11 & -0.16 \\
\hline & & & & & & & $(0.29)$ & & & '(0.24) & & & $(0.20)$ & $(0.23)$ \\
\hline Unemployment insurance coverage (2) & & & & & & & & & & & $1.23^{\star \star}$ & $1.28^{\star \star}$ & $1.35^{\star *}$ & $1.68^{\star \star \star}$ \\
\hline & & & & & & & & & & & $(0.51)$ & $(0.50)$ & $(0.53)$ & $(0.45)$ \\
\hline Spending on active labour market policies (3) & \multicolumn{12}{|c|}{ Social spending (in $\%$ of GDP) } & & \\
\hline 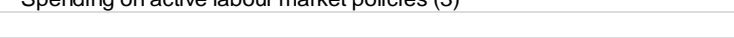 & & & & & & & & $(8.20)$ & $r(7.46)$ & $(7.09)$ & & & & $(10.5)$ \\
\hline Total Social spending & -0.75 & -0.76 & -0.73 & -0.56 & -0.56 & -0.77 & -0.66 & 1.07 & 1.02 & 1.01 & 1.35 & 1.40 & 1.54 & 1.56 \\
\hline & $(1.47)$ & (1.58) & (1.45) & $(1.40)$ & $(1.57)$ & (1.48) & (1.40) & $(0.90)$ & $(0.89)$ & $(0.91)$ & $(2.37)$ & $(2.39)$ & $(2.44)$ & (1.81) \\
\hline \multicolumn{15}{|l|}{ Technological change \& Globalisation } \\
\hline Ln (openness) & $0.20^{\star *}$ & $0.23^{\star \star *}$ & $0.18^{\star \star}$ & $0.21^{\star \star \star}$ & $0.25^{\star \star \star}$ & $0.20^{\star \star}$ & $0.18^{\star \star}$ & $0.18^{\star \star \star *}$ & $0.16^{\star \star \star}$ & $0.17^{\star \star \star}$ & 0.17 & 0.15 & 0.16 & 0.14 \\
\hline & $(0.080)$ & $(0.089)$ & $(0.076)$ & $(0.077)$ & $(0.093)$ & $(0.082)$ & $(0.074)$ & (0.059) & (0.060) & (0.055) & ) $(0.11)$ & $(0.11)^{\prime}$ & $(0.11)$ & $(0.12)$ \\
\hline Ln (MFP change) & -0.28 & -0.28 & -0.28 & -0.24 & -0.24 & -0.27 & -0.22 & -0.30 & -0.30 & -0.31 & -0.39 & -0.38 & -0.35 & 0.062 \\
\hline & $(0.26)$ & $(0.27)$ & $(0.26)$ & $(0.23)$ & $(0.23)$ & $"(0.27) "$ & " $(0.26)$ & $(0.23)$ & $(0.23)$ & $(0.23)$ & $"(0.48)$ " & "(0.48) " & $(0.48)$ & $(0.46)$ \\
\hline \multicolumn{15}{|l|}{ Labour market, sociodemographic conditions and } \\
\hline In (Unemployment rate) & $0.17^{\star \star \star}$ & $0.17^{\star \star \star}$ & $0.18^{\star \star \star}$ & $0.18^{\star \star \star}$ & $0.18^{\star \star \star}$ & $0.17^{\star \star \star}$ & $0.18^{\star \star \star}$ & $0.13^{\star \star \star}$ & $0.13^{\star \star \star}$ & $0.13^{\star \star \star}$ & 0.14 & 0.14 & 0.16 & $0.29^{\star \star \star}$ \\
\hline \multirow{3}{*}{ Earnings inequality: In (d9d1) } & $(0.043)$ & $(0.045)$ & $"(0.042) "$ & (0.039) & $(0.047)$ & $"(0.042)$ & $"(0.040)$ & $(0.029)$ & (0.030) & "(0.032) & )$^{\prime}(0.12)$ & $"(0.12)$ & $"(0.12)$ & (0.089) \\
\hline & $-0.58^{\star \star \star}$ & $-0.57^{\star \star \star}$ & $-0.57^{\star \star \star}$ & $-0.64^{\star \star \star}$ & $-0.56^{\star \star \star}$ & $-0.56^{\star \star \star}$ & $-0.57^{\star \star \star}$ & $-0.55^{\star \star}$ & $-0.55^{\star \star}$ & $-0.56^{\star \star}$ & $-0.72^{\star \star}$ & $-0.71^{\star \star}$ & $-0.70^{\star \star}$ & -0.49 \\
\hline & $(0.21)$ & $(0.20)$ & $(0.20)$ & $(0.21)$ & $(0.19)$ & $(0.20)$ & $(0.20)$ & $(0.22)$ & $(0.22)$ & $(0.22)$ & $"(0.35) "$ & $(0.35)^{\prime \prime}$ & $(0.35)$ & " (0.34) \\
\hline \multirow{2}{*}{ Share of workless families with children among working-age households } & 1.32 & 1.64 & 1.22 & $2.08^{*}$ & 2.05 & 1.15 & 1.00 & 1.42 & 1.28 & 1.23 & 1.52 & 1.58 & $\begin{array}{r}1.66 \\
-1.5\end{array}$ & 1.16 \\
\hline & $(1.35)$ & $(1.36)$ & $(1.36)$ & $(1.23)$ & $(1.27)$ & $(1.37) "$ & '(1.44) & $(1.33)$ & $(1.38)$ & $(1.34)$ & $(1.03)$ & $(1.05)^{\prime}$ & $(1.11)$ & $(0.88)$ \\
\hline Time fixed effects & Yes & Yes & Yes & Yes & Yes & Yes & Yes & Yes & Yes & Yes & Yes & Yes & Yes & Yes \\
\hline Country fixed effects & Yes & Yes & Yes & Yes & Yes & Yes & Yes & Yes & Yes & Yes & Yes & Yes & Yes & es \\
\hline Observations & 295 & 295 & 295 & 295 & 295 & 295 & 295 & 262 & 262 & 262 & 141 & 141 & 141 & 131 \\
\hline Difference in Sargan test & 1.95 & 1.94 & 1.82 & 1.40 & 0.98 & 3.29 & 3.28 & 0.61 & 0.45 & 1.17 & 4.04 & 4.16 & 4.33 & 7.38 \\
\hline Degree of freedom & 2 & 2 & 2 & 2 & 2 & 2 & 2 & 3 & 3 & 3 & 3 & 3 & 3 & 4 \\
\hline $\mathrm{p}$-value & 0.38 & 0.38 & 0.40 & 0.50 & 0.61 & 0.19 & 0.19 & 0.89 & 0.93 & 0.76 & 0.26 & 0.24 & 0.23 & 0.12 \\
\hline KP Under identification test & 10.70 & 11.80 & 13.80 & 14.00 & 9.60 & 7.18 & 8.30 & 9.47 & 12.30 & 7.34 & 11.00 & 9.69 & 11.40 & 7.83 \\
\hline Degree of freedom & 1 & 1.00 & 1 & 1 & $\begin{array}{c}3.00 \\
1\end{array}$ & 1.10 & $\begin{array}{c}0.00 \\
1\end{array}$ & 1 & 1 & $\begin{array}{c}1.04 \\
1\end{array}$ & 1 & 1 & 1.40 & $\begin{array}{c}1.00 \\
1\end{array}$ \\
\hline p-value & 0.00 & 000 & 0.00 & 0.00 & 000 & 0.01 & 0.00 & 000 & 000 & 0.01 & 0.00 & 0.00 & 000 & 0.01 \\
\hline
\end{tabular}


Table A.18. Transfers and redistribution: a focus on public policies for families and children - IV estimation

\begin{tabular}{|c|c|c|c|c|c|c|c|c|c|c|c|c|c|c|}
\hline \multirow{2}{*}{\begin{tabular}{|l} 
Dependent variable is In(redistribution) \\
Policy indicators \\
Total public spending on families as a share of GDP
\end{tabular}} & 1 & 2 & 3 & 4 & 5 & 6 & 7 & 8 & 9 & 10 & 11 & 12 & 13 & 14 \\
\hline & 9.04 & & & & & & & & & & & & & \\
\hline Public spending on cash benefits for families as a share of GDP & (49.2), & 2.70 & & & & & & & & & & & & \\
\hline & & $(5.43)$ & & & & & & & & & & & & \\
\hline Public spending on in-kind benefits for families as a share of GDP & & & $\begin{array}{l}12.1 \\
(12.7)\end{array}$ & & & & & & & & & & & \\
\hline Public spending on tax breaks for families as a share of GDP & & & & 3.88 & & & & & & & & & & \\
\hline Public spending on early childhood education and care as a share of GDP & & & & (19.0) & $26.6^{*+*+}$ & & & & & & & & & \\
\hline & & & & & (7.98) & & & & & & & & & \\
\hline Length of paid maternity leave & & & & & & $0.096^{\star \star}$ & & & & & & & & \\
\hline Length of paid paternity leave & & & & & & $(0.039)$ & & & & & & & & \\
\hline & & & & & & & (0.16) & & & & & & & \\
\hline Proportional difference in net transfers by single and equal-dual earner couples, household earnings at $133 \%$ of the AW & & & & & & & & -0.033 & & & & & & \\
\hline Proportional difference in net transfers by single and equal-dual earner couples, household earnings at $200 \%$ of the AW & & & & & & & & $(0.021)$ & & & & & & \\
\hline Labour market situation of women & & & & & & & & & (0.40) & & & & & \\
\hline Gender-gap in the full-time equivalent employment to population ratio & & & & & & & & & & $-2.67^{* *}$ & & & & \\
\hline Employment rate of mothers & & & & & & & & & & (1.15) & $0.79^{*}$ & & & \\
\hline Employment rate of partnered mothers & & & & & & & & & & & $(0.46)$ & & & \\
\hline Fmnloument raten foplenarents mothere & & & & & & & & & & & & (0.50) & & \\
\hline 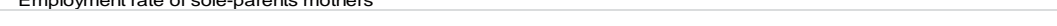 & & & & & & & & & & & & & ( & \\
\hline Women employment rate & & & & & & & & & & & & & & $=0.0056$ \\
\hline $\begin{array}{l}\text { Social spending (in\% of GDP) } \\
\text { Total Social spending }\end{array}$ & $=0.58$ & 0.97 & -0.099 & 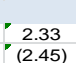 & $=0.86$ & $=\frac{1.10}{(1.28)}$ & 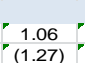 & {$\left[\begin{array}{ll}-0.33 \\
(1.86)\end{array}\right.$} & $=0.24$ & $=(1.60)$ & $=\frac{1.76}{(1.56)}$ & 0.2 .29 & $=2.23$ & {$\left[\begin{array}{l}1.13 \\
(1.41)\end{array}\right.$} \\
\hline Technological change \& Globalisation & & & & & & & & & & & & & & \\
\hline Ln (openness) & $=0.10$ & $(0.090)$ & $(0.097)$ & {$\left[\begin{array}{ll}-0.14 \\
(0.23)\end{array}\right.$} & $(0.10)$ & $(0.087)$ & $=(0.11)$ & $=0.15$ & $(0.11)$ & $=0.34)^{\circ}$ & $r(0.062)$ & 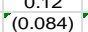 & $=0.074$ & {$\left[\begin{array}{ll}0.22^{* * *} \\
(0.082)\end{array}\right.$} \\
\hline Ln (MFP change) & 0.10 & $-0.43^{*+x}$ & $\begin{aligned}-0.28^{*} \\
(0.15)\end{aligned}$ & $\left.\begin{array}{l}0.42 \\
0.55\end{array}\right]$ & $\begin{array}{ccc}-0.32^{+*} \\
(0.16)\end{array}$ & {$\left[\begin{array}{r}-0.37 \\
(0.26\end{array}\right]$} & {$\left[\begin{array}{l}-0.40 \\
(0.25)\end{array}\right.$} & $\begin{array}{c}-0.46^{* *} \\
(0.22)\end{array}$ & 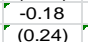 & $\begin{array}{l}-0.36^{+* x}= \\
(0.18)\end{array}$ & {$\left[\begin{array}{l}-0.14 \\
(0.14)\end{array}\right.$} & {$\left[\begin{array}{ll}-0.094 \\
(0.15)\end{array}\right.$} & {$\left[\begin{array}{l}-0.18 \\
(0.14)\end{array}\right.$} & $-0.39^{*}$ \\
\hline Labour market, sociodemographic conditions and earnings inequality & & & & & & & & & & & & & & \\
\hline & $=0.13$ & 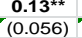 & 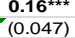 & $\left(\begin{array}{ll}0.0641^{\star} \\
(0.06)\end{array}\right.$ & $\begin{array}{ll}0.1 .4 * * t \\
(0.041)\end{array}$ & $(0.052)$ & 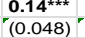 & $\begin{array}{ll}0.1 .19+4 \pi \\
(0.070)\end{array}$ & 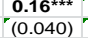 & $\frac{-0.010}{(0.062)}$ & 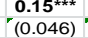 & 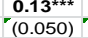 & (0.072)" & $\Rightarrow(0.048)$ \\
\hline Earnings inequality: $\ln (\mathrm{d} 9 \mathrm{~d} 1$ ) & 0.10 & $-0.50^{*+* x}$ & $-0.57^{\star \star \star}$ & 0.16 & $-0.56^{+*+\infty}$ & $-0.61^{\star}$ & $-0.64^{+*}$ & $-0.66^{* * *}$ & $-0.63^{*+\infty}$ & $-0.46^{x+* x}$ & $-0.46^{+* x+}$ & & $-0.45^{\star \star}$ & $-0.45^{*+*}$ \\
\hline & $(0.37)$ & $=(0.17)$ & $(0.16)$ & $(0.27)$ & $(0.19)$ & (0.31) & $(0.31)^{\prime}$ & $(0.21)$ & $(0.20)$ & $=0.16)$ & $=(0.15)$ & $\begin{array}{l}(0.15) \\
255\end{array}$ & $(0.18)$ & $=(0.17)$ \\
\hline Share of workless families with children among working-age households & $=0.0 .46$ & $=0.65$ & {$\left[\begin{array}{l}1.73 \\
(1.11)\end{array}\right.$} & {$\left[\begin{array}{l}-0.26 \\
(0.86)\end{array}\right.$} & $=0.088,(0.99)$ & $\begin{array}{l}0.47 \\
(0.86)\end{array}$ & $\begin{array}{l}0.40 \\
(0.82) \\
(0.0)\end{array}$ & $\begin{array}{l}-3.20^{*} \\
(1.71) \\
\end{array}$ & $\begin{array}{l}\left.2.0^{*}\right)^{*} \\
(1.12)^{n}\end{array}$ & $\begin{array}{l}0.98 \\
(1.23) \\
-\end{array}$ & $\begin{array}{l}-2.35 \\
(1.58) \\
\end{array}$ & $\begin{array}{l}2.52 \\
(1.69)\end{array}$ & $\begin{array}{l}2.95 \\
(2.09)^{\prime}\end{array}$ & $\begin{array}{l}0.60 \\
(0.76) \\
\end{array}$ \\
\hline $\begin{array}{l}\text { Time fixed effects } \\
\text { Thto }\end{array}$ & Yes & Yes & Yes & Yes & Yes & Yes & $Y_{E}$ & Yes & Yes & Yes & Yes & Yes & Yes & Yes \\
\hline $\begin{array}{l}\text { Coun } \\
\text { Obse }\end{array}$ & $\begin{array}{l}\text { Yes } \\
101\end{array}$ & 32 & 27 & 2 & & & & Yes & & & & Yes & & Yes \\
\hline Difference in Sargan test & 0.69 & $\begin{array}{l}323 \\
0.10\end{array}$ & 0.86 & $\begin{array}{l}102 \\
0.35\end{array}$ & 6.40 & $\begin{array}{l}312 \\
0.37\end{array}$ & 0.17 & $\begin{array}{l}295 \\
1.52\end{array}$ & 1.46 & 2.09 & $\begin{array}{l}246 \\
0.25\end{array}$ & 0.50 & 3.03 & $\begin{array}{l}350 \\
1.02\end{array}$ \\
\hline Degree of freedom & 2 & 2 & & 2 & 2 & & & 2 & : & & 2 & 2 & 2 & 2 \\
\hline & $\begin{array}{l}0.71 \\
139\end{array}$ & $\begin{array}{r}0.95 \\
1530\end{array}$ & $\begin{array}{l}0.65 \\
13.30\end{array}$ & $\begin{array}{l}0.84 \\
262 \\
262\end{array}$ & $\begin{array}{c}0.04 \\
1260\end{array}$ & $\begin{array}{c}0.83 \\
1210\end{array}$ & $\begin{array}{l}0.92 \\
8.17 \\
-17\end{array}$ & $\begin{array}{l}0.47 \\
0.49\end{array}$ & $\begin{array}{l}0.48 \\
9.63 \\
0\end{array}$ & $\begin{array}{r}0.35 \\
12.10\end{array}$ & $\begin{array}{l}0.88 \\
970\end{array}$ & $\begin{array}{c}0.78 \\
1200\end{array}$ & $\begin{array}{l}0.22 \\
5.10\end{array}-2$ & 0.60 \\
\hline $\begin{array}{l}\text { KP Under identification test } \\
\text { Degree of freedom }\end{array}$ & 1 & 1 & 1 & $\begin{array}{l}2.02 \\
1 \\
0.51\end{array}$ & 1 & 1 & 1 & $\begin{array}{l}0.49 \\
1\end{array}$ & $\begin{array}{c}9.00 \\
1\end{array}$ & 1 & 1 & 1 & 1 & $\begin{array}{l}5.06 \\
1\end{array}$ \\
\hline$p$-value & 0.24 & & & & & 0.00 & 0.00 & 0.48 & 0.00 & 0.00 & 0.00 & 0.00 & 0.02 & 0.00 \\
\hline
\end{tabular}

Note: Dependent variable is the natural logarithm of redistribution. Standard errors are clustered at the country level. R squared does not incorporate the effect of country fixed effects. All policy variables are instrumented by their first lags.

Significance levels: $* \mathrm{p}<.1 ; * * \mathrm{p}<.05 ; * * * \mathrm{p}<.01$, Bold highlights significant coefficients 
Table A.19. The effects of old-age pension systems and early retirement incentives on redistribution to the working-age population - IV estimation

\begin{tabular}{|c|c|c|c|c|c|c|c|c|c|c|c|c|c|}
\hline Dependent variable is $\ln$ (redistribution) & 1 & 2 & 3 & 4 & 5 & 6 & 7 & 8 & 9 & 10 & 11 & 12 & 13 \\
\hline \multicolumn{14}{|l|}{ Old-age pension parameters (1) } \\
\hline Normal retirement age & $\begin{array}{c}-0.011 \\
(0.0094)\end{array}$ & & & & & & & & & & & & \\
\hline Normal retirement age, men & & -0.0043 & & & & & & & & & & & \\
\hline \multirow[t]{2}{*}{ Normal retirement age, women } & & & -0.013 & & & & & & & & & & \\
\hline & & & $(0.0083)$ & & & & & & & & & & \\
\hline \multirow[t]{2}{*}{ Minimum retirement age } & & & & $0.0077^{* *}$ & & & & & & & & & \\
\hline & & & & $(0.0039)$ & & & & & & & & & \\
\hline \multirow[t]{2}{*}{ Minimum retirement, men } & & & & & $0.012^{\star \star \star \star}$ & & $0.020^{\star \star *}$ & $0.013^{* \star *}$ & $0.020^{\star *}$ & $0.016^{* \star \star}$ & $0.016^{\star \star \star}$ & & \\
\hline & & & & & $(0.0037)$ & & '(0.0047) & ' $(0.0034)$ & $(0.0084){ }^{\prime}$ & $(0.0055)$ & $(0.0058)$ & & \\
\hline \multirow[t]{2}{*}{ Minimum retirement, women } & & & & & & 0.0030 & & & & & & & \\
\hline & & & & & & '(0.0045) & & & & & & & \\
\hline \multirow[t]{2}{*}{ Replacement rate from the old-age pension system at age 60 (2) } & & & & & & & $0.12^{\text {** }}$ & & & & & & \\
\hline & & & & & & & $(0.051)$ & & & & & & \\
\hline \multirow{2}{*}{ Replacement rate from the old-age pension system at age 65 (2) } & & & & & & & & 0.12 & & & & & \\
\hline & & & & & & & & $(0.13)$ & & & & & \\
\hline \multirow[t]{2}{*}{ Replacement rate from the old-age pension system at age 69 (2) } & & & & & & & & & 1.01 & & & & \\
\hline & & & & & & & & & $(0.87)$ & & & & \\
\hline \multirow[t]{2}{*}{ Replacement rate from the old-age pension system between ages 60 \& 65 (average) (2) } & & & & & & & & & & 0.060 & & & \\
\hline & & & & & & & & & & $(0.069)$ & & & \\
\hline \multirow[t]{2}{*}{ Replacement rate from the old-age pension system between ages 65 \& 69 (average) (2) } & & & & & & & & & & & 0.57 & & \\
\hline & & & & & & & & & & & $(0.68)$ & & \\
\hline \multicolumn{14}{|l|}{ Effective retirement age } \\
\hline \multirow[t]{2}{*}{ Average effective retirement age, men } & & & & & & & & & & & & $-0.032^{* *}$ & \\
\hline & & & & & & & & & & & & $(0.014)$ & \\
\hline \multirow{2}{*}{ Average effective retirement age, women } & & & & & & & & & & & & & -0.012 \\
\hline & & & & & & & & & & & & & $(0.011)$ \\
\hline Social spending (in \% of GDP) & & & & & & & & & & & & & \\
\hline Social spending on old-age population & $\left(\begin{array}{c}4.19 \\
(3.60)\end{array}\right.$ & $\begin{array}{l}4.33 \\
(3.72)\end{array}$ & $\left(\begin{array}{l}4.07 \\
(3.52)\end{array}\right.$ & $\begin{array}{c}3.70 \\
(3.40)\end{array}$ & $\begin{array}{c}3.12 \\
(3.06)\end{array}$ & (3.10 & $\begin{array}{l}3.12 \\
(3.17)\end{array}$ & $\begin{array}{c}3.05 \\
(3.09)\end{array}$ & $\begin{array}{c}0.51 \\
(3.16)\end{array}$ & $\begin{array}{c}3.03 \\
(3.18)\end{array}$ & $\begin{array}{c}2.19 \\
(3.09)\end{array}$ & $\begin{array}{l}-3.36 \\
(3.89)\end{array}$ & $\begin{array}{l}-4.38 \\
(4.33)\end{array}$ \\
\hline Total Social spending & 2.16 & 1.96 & 2.34 & 2.24 & $2.39^{*}$ & 2.13 & $2.29^{*}$ & $2.37^{\star}$ & $2.16^{*}$ & $2.37^{*}$ & $2.23^{*}$ & $2.46^{*}$ & $2.67^{*}$ \\
\hline & '(1.45)' & $(1.47)$ & $(1.44)^{\prime}$ & $(1.37)$ & $(1.30)^{\prime}$ & $(1.45)$ & $(1.22)^{\prime}$ & $(1.27)^{\prime}$ & $(1.17)^{\prime}$ & (1.29) & $(1.23)$ & $(1.38)^{\prime}$ & (1.59) \\
\hline Technological change \& Globalisation & & & & & & & & & & & & & \\
\hline Ln (openness) & $0.24^{* *}$ & $0.23^{* *}$ & $0.24^{\star *}$ & $0.22^{* *}$ & $0.22^{* *}$ & $0.22^{\star *}$ & $0.21^{*}$ & $0.21^{*}$ & $0.24^{* *}$ & $0.21^{*}$ & 0.19 & $0.19^{* *}$ & $0.23^{\text {** }}$ \\
\hline & $(0.097) "$ & $(0.098)$ & $(0.098)$ & (0.11) & $(0.11)$ & $(0.11)$ & $(0.11)$ & $(0.11)$ & $(0.11)$ & $(0.11)$ & $(0.12)$ & $(0.083) "$ & "(0.096) \\
\hline Ln (MFP change) & -0.12 & -0.13 & -0.093 & -0.047 & -0.041 & -0.052 & -0.066 & $-0.073^{\prime}$ & -0.092 & -0.047 & -0.10 & $-0.45^{\star}$ & $-0.51^{*}$ \\
\hline & $(0.15)$ & $(0.16)$ & $(0.15)$ & $(0.16)$ & $(0.16)$ & $(0.17)$ & $(0.15)^{\prime}$ & $(0.16)$ & $(0.14)^{\prime}$ & $(0.16)$ & $(0.16)^{\prime}$ & $(0.24)^{\prime \prime}$ & $(0.27)$ \\
\hline Labour market, sociodemographic conditions and earnings inequality & & & & & & & & & & & & & \\
\hline Share of $55-65$ in working-age population & -0.98 & -1.00 & -0.97 & -0.95 & -0.97 & -0.89 & -0.52 & -1.07 & -2.02 & -0.85 & -1.48 & 0.57 & 0.78 \\
\hline & $(1.01)$ & $(1.03)$ & $(1.00)$ & $(0.98)$ & $(0.94)$ & $(1.00)$ & $(0.97)$ & $(0.94)$ & $(1.38)$ & $(0.99)$ & (1.16) & $(1.04)$ & (1.16) \\
\hline Old-age dependency ratio & -0.48 & -0.54 & -0.53 & -0.87 & -0.97 & -0.75 & -0.99 & -0.82 & -0.95 & -0.93 & -0.73, & -0.18 & 0.16 \\
\hline In (Unemployment rate) & 0.033 & 0.038 & 0.028 & 0.029 & 0.028 & 0.031 & 0.032 & 0.033 & 0.053 & 0.034 & 0.044 & $\left(0.11^{* *}\right.$ & $0.11^{* *}$ \\
\hline & $"(0.045) "$ & '(0.045) & $"(0.047) "$ & ' (0.045) & $(0.044) "$ & $(0.046) "$ & "(0.045) " & '(0.044) ' & '(0.040) & $"(0.047)$ & $'(0.043){ }^{\prime}$ & '(0.051) " & "(0.051) \\
\hline Earnings inequality: $\ln (\mathrm{d} 9 \mathrm{~d} 1$ ) & $-0.35^{\star \star}$ & $-0.33^{* \star}$ & $-0.37^{* *}$ & $-0.30^{*}$ & $-0.34^{* *}$ & $-0.29^{*}$ & $-0.33^{*}$ & $-0.35^{*}$ & $-0.50^{+* \star *}$ & $-0.33^{*}$ & $-0.42^{\star \star}$ & $-0.66^{* \star x}$ & $-0.67^{*+* x}$ \\
\hline & $(0.16)$ & $(0.17)$ & $(0.15)$ & $(0.18)$ & $(0.17)$ & $(0.17)$ & $(0.18)$ & $(0.18)$ & $(0.18)$ & $(0.18)$ & $(0.18)$ & $(0.22)$ & $(0.24)$ \\
\hline Share of workless families with children among working-age households & 0.84 & 0.95 & 0.78 & 1.18 & 1.23 & 1.08 & 1.25 & 1.08 & 0.89 & 1.16 & 0.93 & 0.30 & 0.64 \\
\hline & $(0.93)$ & $(0.94)$ & $(0.92)^{\prime}$ & $(0.93)$ & $(0.91)^{\prime}$ & $(0.94)^{\prime}$ & $(0.90)^{\prime}$ & $(0.91)^{\prime}$ & $(0.73)$ & $(0.90)$ & $(0.83)^{\prime}$ & $(0.83)^{n}$ & $(0.86)$ \\
\hline Time fixed effects & Yes & Yes & Yes & Yes & Yes & Yes & Yes & Yes & Yes & Yes & Yes & Yes & Yes \\
\hline Country fixed effects & Yes & Yes & Yes & Ye & Yes & Yes & Yes & Yes & Yes & Yes & Yes & Yes & Yes \\
\hline Observations & 229 & 229 & 229 & 224 & 224 & 224 & 224 & 224 & 224 & 224 & 224 & 321 & 321 \\
\hline Difference in Sargan test & 3.24 & 3.24 & 3.19 & 2.12 & 2.35 & 2.09 & 5.48 & 2.35 & 2.43 & 3.06 & 2.52 & 1.87 & 1.97 \\
\hline Degree of freedom & 3 & 3 & 3 & 3 & 3 & 3 & 4 & 4 & 4 & 4 & 4 & 3 & 3 \\
\hline $\mathrm{p}$-value & 0.36 & 0.36 & 0.36 & 0.55 & 0.50 & 0.55 & 0.24 & 0.67 & 0.66 & 0.55 & 0.64 & 0.60 & 0.58 \\
\hline KP Under identification test & 12.80 & 13.20 & 12.20 & 10.50 & 9.60 & 11.50 & 10.20 & 1.82 & 1.21 & 12.00 & 2.49 & 8.78 & 15.90 \\
\hline Degree of freedom & 1 & 1 & 1 & 1 & 1 & 1 & 1 & 1 & 1 & 1 & 1 & 1 & 1 \\
\hline
\end{tabular}

Note: Dependent variable is the natural logarithm of redistribution. Standard errors are clustered at the country level. (1) Legal age conditions for someone who enters the labour market at age 25 and exclude minimum contribution period conditions. The idea is to use legal ages that are referred to in public as the typical retirement ages. (2) Men. Excluding any kind of benefit received from. Unemployment benefit schemes or disability pension schemes. All policy variables are instrumented by their first lags.

Significance levels: * $\mathrm{p}<.1 ; * * \mathrm{p}<.05 ; * * * \mathrm{p}<.01$

Bold highlights significant coefficients 
Table A.20. Redistribution: the effects of social spending and tax revenues - Median regressions

\begin{tabular}{|c|c|c|c|c|c|c|c|c|c|c|c|}
\hline $\begin{array}{l}\text { Dependent variable is In(redistribution) } \\
\text { Social spending (in\% of GDP) }\end{array}$ & 1 & 2 & 3 & 4 & 5 & 6 & 7 & 8 & 9 & 10 & 11 \\
\hline \multirow{2}{*}{$\begin{array}{l}\text { Social spending (in\% of GDP) } \\
\text { Social spending on cash support to working-age population }\end{array}$} & $3.67^{\star \star *}$ & & & & & & & & & & \\
\hline & $(1.22)$ & & & & & & $(1.33)$ & & $(1.16)$ & & $(1.53)$ \\
\hline Total Social spending on working-age population & & $2.29^{\star \star}$ & & & & & & & & & \\
\hline Total Social spending on old-age population & & 0.78 & & & & & & & & & \\
\hline \multirow{2}{*}{$\begin{array}{l}\text { Total Social spending } \\
\text { Tax revenues (in } \% \text { of }\end{array}$} & & & $\begin{array}{l}1.72^{\star \star} \\
(0.86)\end{array}$ & & & & & $\begin{array}{r}1.52^{\star *} \\
(0.73)\end{array}$ & & $\begin{array}{ll}1.37 \\
(1.07)\end{array}$ & \\
\hline & & & & & & & & & & & \\
\hline nd employees' SSC & & & & $=1.99^{\star *}$ & & & 1.39 & & $1.22^{\star \star}$ & & 1.38 \\
\hline Tax revenues from $\mathrm{PT}$ & & & & (0.86) & 2.06 & & & & $(0.54)$ & & (0.93) \\
\hline \multirow{2}{*}{$\begin{array}{l}\text { Tax revenues from employees' SSC } \\
\text { Total Tax revenues }\end{array}$} & & & & & 1.58 & & & & & & \\
\hline & & & & & $(1.50)$ & 0.99 & & 0.43 & & 0.64 & \\
\hline \multirow{2}{*}{\multicolumn{12}{|c|}{$\begin{array}{l}\text { Interaction between openness and }\left(^{*}\right): \\
\text { Tax revenues from PIT and employees' SSC }\end{array}$}} \\
\hline & & & & & & & & & $=\frac{-0.91}{(0.72)}$ & & \\
\hline Total tax revenues & & & & & & & & & & -0.45 & \\
\hline \multirow[t]{2}{*}{ Social spending on cash support to working-age population } & & & & & & & & & & $(0.64)$ & -0.37 \\
\hline & & & & & & & & & & & $(1.03)$ \\
\hline Ln (openness) & $\begin{array}{l}0.15^{* *} \\
(0.059)\end{array}$ & $\begin{array}{l}0.14 \\
(0.084)\end{array}$ & $\begin{array}{l}0.082 \\
(0.090)\end{array}$ & $\begin{array}{l}\mathbf{0 . 1 2}^{*} \\
(0.066)\end{array}$ & 0.13 & $\stackrel{\mathbf{0 . 1 4}^{\star}}{(0.081)}$ & 0.086 & 0.082 & $\frac{\mathbf{0 . 1 3}^{\star \star}}{(0.061)}$ & $=0.084$ & 0.090 \\
\hline Ln (MFP change) & $-0.26^{*}$ & -0.23 & -0.21 & $-0.48^{\star \star}$ & $-0.47^{*}$ & $-0.37^{*}$ & $=-0.24$ & $=-0.16$ & -0.28 & -0.11 & $\begin{array}{l}-0.19 \\
-0.19)\end{array}$ \\
\hline \multicolumn{2}{|l|}{ Labour market, sociodemographic conditions and earnings inequality } & & & & & & & & & & \\
\hline $\begin{array}{l}\text { In(Unemployment rate) } \\
\text { In }\end{array}$ & $\frac{0.088^{\star *}}{(0.043)}$ & $\begin{array}{c}0.11^{*} \\
(0.056)\end{array}$ & $\begin{array}{ll}\mathbf{0}^{-098^{*}} \\
(0.050)\end{array}$ & 0.14 (0.035) & $\frac{0.13 * \star \star}{(0.038)}$ & $0.17^{\star \star *}$ & $=0.064$ & $\frac{0.10^{\star *}}{(0.047)}$ & $=0.065$ & $\begin{array}{l}0.11 \\
(0.072)\end{array}$ & $=0.069$ \\
\hline Earnings inequality: In (d9d1) & -0.24 & $-0.35^{\star \star}$ & $-0.33^{\star \star \star}$ & -0.15 & -0.16 & -0.24 & -0.18 & $-0.26^{\star}$ & -0.13 & -0.20 & -0.23 \\
\hline \multirow{2}{*}{ Share of workless families with children among working-age households } & $(0.16)$ & $(0.14)$ & $(0.12)$ & $(0.26)$ & $.0 .28)$ & $=(0.20)$ & $=(0.42)$ & $(0.15)$ & $(0.33)$ & $\because(0.27)$ & $:(0.20)$ \\
\hline & $=0.11$ & $(0.73)$ & $(0.78)$ & $(0.85)$ & $(0.97)$ & $(1.28)$ & $=0.77)$ & $(0.67)$ & $=0.92$ & $=0.95$ & $\begin{array}{l}0.93 \\
(0.87)\end{array}$ \\
\hline Time fixed effects & Yes & Yes & Yes & $\begin{array}{ll}\text { Yes } \\
\text { Yos }\end{array}$ & Yes & Yes & Yes & Yes & Yes & Yes & Yes \\
\hline Country fixed effects & Yes & Yes & Yes & Yes & Yes & Yes & $\begin{array}{r}\text { Yes } \\
318\end{array}$ & $\begin{array}{l}\text { Yes } \\
\text {. }\end{array}$ & $\begin{array}{l}\text { Yes } \\
318\end{array}$ & & $\begin{array}{l}\text { Yes } \\
318\end{array}$ \\
\hline $\begin{array}{l}\text { Observations } \\
\text { R squared }\end{array}$ & 328 & $\begin{array}{ll}328 \\
0.968\end{array}$ & $\begin{array}{l}356 \\
0.969\end{array}$ & 0.972 & $\begin{array}{l}344 \\
0.972\end{array}$ & 357 & $\begin{array}{l}318 \\
0.975\end{array}$ & $\begin{array}{l}356 \\
0.969\end{array}$ & $\begin{array}{ll}318 \\
0.976\end{array}$ & 356 & 0.975 \\
\hline
\end{tabular}

Note: Dependent variable is the natural logarithm of redistribution. Standard errors are clustered at the country level. $(*)$ Every variable in the interactions is demeaned. Results are based on conditional quantile regressions at the median.

Significance levels: * $\mathrm{p}<.1 ; * * \mathrm{p}<.05 ; * * * \mathrm{p}<.01$

Bold highlights significant coefficients 
Table A.21. Taxes and redistribution: a focus on the overall progressivity of personal income taxes on wage earnings - Median regressions

\begin{tabular}{|c|c|c|c|c|c|c|c|c|c|c|c|c|c|c|c|c|c|}
\hline $\begin{array}{l}\text { Dependent variable is In(redistribution) } \\
\text { Tax parameters }\end{array}$ & 1 & 2 & 3 & 4 & 5 & 6 & 7 & 8 & 9 & 10 & 11 & 12 & 13 & 14 & 15 & 16 & 17 \\
\hline$\frac{\text { Progressivity of personal income taxes }(1)}{\text { Overall structural progression of personal income taxes on wage earnings }}$ & $0.41^{\star \star \star *}$ & $0.40^{\star *}$ & $0.43^{\star \star * *}$ & $0.45^{* * *}$ & & & & & & & & & & & & & \\
\hline & (0.15) & $(0.19)$ & $(0.13)$ & $(0.15)$ & & & & & & & & & & & & & \\
\hline $\begin{array}{l}\text { Average effective tax rates across the distribution (1) } \\
\text { Average effective tax rate at } 67 \% \text { of the AW }\end{array}$ & & 0.20 & & -0.68 & {$\left[\begin{array}{ccc}-0.90 \\
0\end{array}\right.$} & $=-0.89$ & -0.70 & $=-0.52$ & -0.37 & $=-0.29$ & -0.21 & -0.23 & $-0.16:$ & -0.14 & $=-0.072$ & -0.016 & 0.0079 \\
\hline Average effective tax rate at $100 \%$ the $\mathrm{AW}$ & & & 0.63 & 0.97 & $: 1.45$ & & & & & & & & & & & & \\
\hline Average effective tax rate at $133 \%$ of the $\mathrm{AW}$ & & & & $(1.06)$ & (1.15) & $142^{* *}$ & & & & & & & & & & & \\
\hline & & & & & & $r(0.68)$ & & & & & & & & & & & \\
\hline Average effective tax rate at $167 \%$ of the $\mathrm{AW}$ & & & & & & & $1.21^{\star \star}$ & & & & & & & & & & \\
\hline Average effective tax rate at $200 \%$ of the $\mathrm{AW}$ & & & & & & & & $1.16^{* \star * *}$ & & & & & & & & & \\
\hline & & & & & & & & {$[(0.39)$} & & & & & & & & & \\
\hline Average effective tax rate at $233 \%$ of the $\mathrm{AW}$ & & & & & & & & & $1.08^{\star \star \star}$ & & & & & & & & \\
\hline Average effective tax rate at $267 \%$ of the $\mathrm{AW}$ & & & & & & & & & (0.38) & $1.04^{* \star *}$ & & & & & & & \\
\hline Average effective tax rate at $300 \%$ of the $\mathrm{AW}$ & & & & & & & & & & $(0.33)$ & $0.96^{\star \star \star *}$ & & & & & & \\
\hline & & & & & & & & & & & $(0.36)$ & & & & & & \\
\hline Average effective tax rate at $333 \%$ of the $\mathrm{AW}$ & & & & & & & & & & & & $1.00^{* *}$ & & & & & \\
\hline Average effective tax rate at $367 \%$ of the $\mathrm{AW}$ & & & & & & & & & & & & $(0.42)$ & $0.96^{* \star *}$ & & & & \\
\hline & & & & & & & & & & & & & $(0.37)$ & & & & \\
\hline Average effective tax rate at $400 \%$ of the $\mathrm{AW}$ & & & & & & & & & & & & & & $0.91^{\star *}$ & & & \\
\hline Average effective tax rate at $433 \%$ of the $A W$ & & & & & & & & & & & & & & $(0.39)$ & $0.87^{\star \star * *}$ & & \\
\hline Averace effective tax rate at $467 \%$ of the $A W$ & & & & & & & & & & & & & & & $(0.33)$ & & \\
\hline Average effective tax rate at $467 \%$ of the $A W$ & & & & & & & & & & & & & & & & $0.85^{\star \star *}$ & \\
\hline Average effective tax rate at $500 \%$ of the $\mathrm{AW}$ & & & & & & & & & & & & & & & & & $0.82^{* \star *}$ \\
\hline $\begin{array}{l}\text { Tax revenues } \\
\text { Total Tax revenues (\% of GDP) }\end{array}$ & 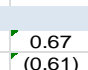 & 0.58 & {$\left[\begin{array}{l}0.53 \\
(0.79)\end{array}\right.$} & $\begin{array}{r}0.62 \\
(0.56)\end{array}$ & {$\left[\begin{array}{l}0.66 \\
0.711\end{array}\right.$} & $r_{0.5}^{0.5}$ & $=0.5$ & {$\left[\begin{array}{l}0.53 \\
(0.55)\end{array}\right.$} & 0. & {$\left[\begin{array}{l}0.46 \\
(0.53)\end{array}\right.$} & $=0.39$ & 0.35 & 0.35 ? & $=0.37$ & $=0.33$ & 0.32 & $=0.31$ \\
\hline Technological change \& Globalisation & & & & & & & & & & & & & & & & & \\
\hline Ln (openness) & 0.14 & {$\left[\begin{array}{ll}0.13 \\
0.11)\end{array}\right.$} & $=0.13$ & $=0.14^{\star}$ & $=0.12$ & $=0.14$ & $\frac{0.16^{\star}}{(0.088)}$ & $\begin{array}{ll}0.16^{*} \\
(0.088)\end{array}$ & $0.16^{*}$ & $\frac{0.17 * x}{(0.083)}$ & $0.17 \star x$ & $(0.081)$ & $\left.0.16^{\star *}\right)$ & $\frac{0.16^{*}}{(0.083)}$ & $\left.0.17^{\star \star}\right)$ & $\left(0.17^{\star}\right.$ & $\mid \begin{array}{ll}0.17 * * \\
(0.082)\end{array}$ \\
\hline Ln (MFP change) & $=0.20$ & -0.20 & -0.18 & -0.22 & -0.21 & -0.21 & $=0.24$ & $=0.23$ & -0.21 & -0.20 & -0.18 & -0.14 & -0.15 & -0.16 & -0.16 & -0.16 & -0.16 \\
\hline itions and earnings inequality & & & & & & & & & & & & & & & & & \\
\hline In(Unemployment rate) & $0.14^{* * *}$ & 0.14 & $0.13^{\star \star \star}$ & $0.13^{\star \star *}$ & $0.13^{* * *}$ & $0.14^{* \star * *}$ & $0.13^{\star \star *}$ & $0.13^{* * * *}$ & $0.13^{* \star \star}$ & $0.13^{* \star *}$ & $0.13^{\star \star \star}$ & $0.13^{\star \star \star}$ & $0.13^{\star \star \star *}$ & $0.13^{\star * *}$ & $0.13^{\star \star \star}$ & $0.13^{\star * \star}$ & $x^{*} 0.13^{* \star \star * *}$ \\
\hline Earnings inequality: In (d9d1) & -0.18 & $=0.040$ & -0.17 & & -0.24 m & -0.28 & -0.26 . & -0.24) & $(-0.25$. & -0.20 & -0.20 & -0.18 & -0.17 & -0.16 & -0.16 . & 15 & 14) \\
\hline & $(0.23)$ & & $(0.23)$ & $(0.19)$ & $(0.19)$ & $(0.18)$ & $(0.16)$ & $(0.19)$ & $(0.19)$ & $(0.17)$ & $(0$ & $(0.22)$ & $(0.19)$ & $(0.20)$ & $(0.26)$ & $(0.24)$ & 21) \\
\hline Share of workless families with children among working-age households & 1.01 & {$\left[\begin{array}{ll}1.07 \\
0.99\end{array}\right.$} & 1.15 & 0.92, & 1.09 & 0.71 & $0.74 \%$ & 0.61 & 0.53 & 0.52 & $(0.45)$ & 0.42 & 0.42 & 0.39 & 0.41 & 0.42 & 0.40 \\
\hline Time fix & Yes & Yes & Yes & $\mathrm{Ye}$ & Yes & Yes & Yes & $\mathrm{Ye}$ & Yes & Ye & Yes & Yes & Yes & (0.8) & $\begin{array}{l}\text { (0.10) } \\
\text { Yes }\end{array}$ & $\begin{array}{l}\text { (0.10) } \\
\text { Yes }\end{array}$ & $\frac{74)}{\text { es }}$ \\
\hline Country & $Y$ & Ye & Yes & 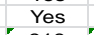 & Non & Yes & & 1es & Yes & Non & 000 & & & 300 & es & Tes & S \\
\hline Observatio & 318 & 318 & 318 & 318 & 322 & 322 & 322 & 322 & 322 & : 322 & 322 & 322 & 322 & 322 & 322 & 322 & 322 \\
\hline R squared & & & & & & & & & & & & & & & & & 0.971 \\
\hline
\end{tabular}

Note: Dependent variable is the natural logarithm of redistribution. Standard errors are clustered at the country level. (1) Data refer to single taxpayers without children. Results are based on conditional quantile regressions at the median.

Significance levels: * $\mathrm{p}<.1 ; * * \mathrm{p}<.05 ; * * * \mathrm{p}<.01$, Bold highlights significant coefficients 
Table A.22. Taxes and redistribution: a focus on top tax rates and on the taxation of capital income - Median regressions

\begin{tabular}{|c|c|c|c|c|c|c|c|c|c|}
\hline $\begin{array}{l}\text { Dependent variable is } \ln (\text { redistribution) } \\
\text { Tax parameters }\end{array}$ & 1 & 2 & 3 & 4 & 5 & 6 & 7 & 8 & 9 \\
\hline \multicolumn{10}{|l|}{ Top tax rates } \\
\hline Top statutory personal income tax rates & $\mathbf{0 . 4 7}^{*}$ & $\begin{array}{l}\mathbf{0 . 4 8} \\
=(0.20)\end{array}$ & & & & & & & \\
\hline Top marginal tax rates - PIT & & & 0.25 & & & & & & \\
\hline & & & $(0.55)$ & & & & & & \\
\hline Top marginal tax rates - PIT \& employee SSC & & & & $0.45^{\star \star \star}$ & $0.38^{\star \star \star}$ & & & & \\
\hline \multicolumn{4}{|l|}{ Taxation of capital income } & $(0.14)$ & $(0.11)$ & & & & \\
\hline Net personal tax on dividend income & & & & & & 0.29 & $0.30^{\star \star}$ & & \\
\hline & & & & & & $(0.19)$ & $(0.12)$ & & \\
\hline Share of overall tax rate on dividend income collected through the use of $\mathrm{PIT}$ & & & & & & & & 0.17 & $0.19^{\star}$ \\
\hline & & & & & & & & $(0.19)$ & "(0.095) \\
\hline \multicolumn{10}{|l|}{ Average effective tax rates controls( 1 ) } \\
\hline Average effective tax rate at $67 \%$ of the $\mathrm{AW}$ & & -0.32 & & & 0.082 & & -0.25 & & -0.41 \\
\hline & & (0.93) & & & (0.79) & & $(0.89)$ & & $(1.03)$ \\
\hline Average effective tax rate at $100 \%$ the AW & & 0.75 & & & 0.51 & & $1.45^{\star \star}$ & & $1.17^{\star}$ \\
\hline \multicolumn{10}{|l|}{ Tax revenues } \\
\hline Total Tax revenues (\% of GDP) & 0.25 & 0.19 & 0.50 & 0.25 & 0.34 & 0.87 & 0.51 & 0.87 & 0.73 \\
\hline \multicolumn{10}{|l|}{ Technological change \& Globalisation } \\
\hline Ln (openness) & $0.19^{\star \star}$ & $0.17^{\star \star}$ & $0.16^{\star}$ & $0.19^{\star \star}$ & $0.15^{\star \star}$ & 0.096 & 0.051 & 0.13 & 0.070 \\
\hline & $(0.083)$ & $(0.079)$ & $(0.086)$ & $(0.084)$ & $(0.063)$ & $(0.14)$ & $(0.096)$ & $(0.11)$ & $(0.13)$ \\
\hline Ln (MFP change) & -0.080 & -0.033 & -0.098 & -0.22 & -0.088 & -0.082 & -0.13 & -0.10 & -0.13 \\
\hline \multirow{2}{*}{\multicolumn{10}{|c|}{ Labour market, sociodemographic conditions and earnings inequality }} \\
\hline & & & & & & & & & \\
\hline & $(0.036)$ & $(0.024)$ & $(0.047)$ & $(0.036)$ & $(0.025)$ & $(0.046)$ & $(0.027)$ & $(0.047)$ & $(0.047)$ \\
\hline Earnings inequality: In (d9d1) & -0.072 & -0.071 & -0.17 & -0.24 & -0.19 & -0.18 & -0.25 & -0.12 & -0.17 \\
\hline & $(0.44)$ & $(0.18)$ & $(0.20)$ & $(0.16)$ & $(0.15)$ & $(0.26)$ & $(0.18)$ & $(0.19)$ & $(0.18)$ \\
\hline Share of workless families with children among working-age households & 0.56 & 0.53 & 0.97 & 0.91 & 0.79 & 1.41 & 1.04 & 1.52 & 1.06 \\
\hline & $(0.75)$ & $(0.63)$ & $(0.78)$ & $(0.67)$ & $(0.54)$ & $(1.21)$ & $(0.75)$ & $(0.93)$ & $(0.77)$ \\
\hline Time fixed effects & Yes & Yes & Yes & Yes & Yes & Yes & Yes & Yes & Yes \\
\hline Country fixed effects & Yes & Yes & Yes & Yes & Yes & Yes & Yes & Yes & Yes \\
\hline Observations & 326 & 322 & 326 & 326 & 322 & 326 & 322 & 326 & 322 \\
\hline R squared & 0.972 & 0.972 & 0.971 & 0.972 & 0.973 & 0.972 & 0.974 & 0.972 & 0.973 \\
\hline
\end{tabular}

Note: Dependent variable is the natural logarithm of redistribution. Standard errors are clustered at the country level. (1) Data refer to single taxpayers without children. Results are based on conditional quantile regressions at the median.

Significance levels: $* \mathrm{p}<.1 ; * * \mathrm{p}<.05 ; * * * \mathrm{p}<.01$

Bold highlights significant coefficients 
Table A.23. The tax structure and income redistribution - Median regressions

\begin{tabular}{|c|c|c|c|c|c|c|}
\hline Dependent variable is $\ln$ (redistribution) & 1 & 2 & 3 & 4 & 5 & 6 \\
\hline \multicolumn{7}{|l|}{ Tax structure (\% of Total Tax revenue) } \\
\hline \multirow[t]{2}{*}{ Tax revenue share from PIT and employees' SSC } & $0.56^{\star}$ & & & & & \\
\hline & $(0.31)$ & & & & & \\
\hline \multirow[t]{2}{*}{ From PIT } & & 0.53 & & & & \\
\hline & & $(0.41)$ & & & & \\
\hline \multirow[t]{2}{*}{ From employees' SSC } & & 0.69 & & & & \\
\hline & & $(0.48)$ & & & & \\
\hline \multirow[t]{2}{*}{ Tax revenue share from goods and services } & & & -1.17 & -1.06 & & \\
\hline & & & $(0.75)$ & $(0.65)$ & & \\
\hline \multirow[t]{2}{*}{ From production, sale transfer } & & & & & $-1.30^{\star \star}$ & $-1.22^{\star *}$ \\
\hline & & & & & $(0.62)$ & $(0.57)$ \\
\hline \multirow[t]{2}{*}{ From use of goods and perform } & & & & & $-4.49^{\star \star}$ & $-4.50^{\star \star}$ \\
\hline & & & & & $(2.11)$ & $(2.07)$ \\
\hline \multirow[t]{2}{*}{ Tax revenue share from property } & & & 0.059 & & & -0.52 \\
\hline & & & $(0.85)$ & & & $(0.86)$ \\
\hline \multirow[t]{2}{*}{ From Recurrent taxes on immovable property } & & & & 2.16 & & \\
\hline & & & & $(1.74)$ & & \\
\hline \multirow[t]{2}{*}{ From Recurrent taxes on net wealth } & & & & -0.26 & & \\
\hline & & & & $(2.32)$ & & \\
\hline \multirow[t]{2}{*}{ From Estate, inheritance and gift taxes } & & & & -2.18 & & \\
\hline & & & & $(5.91)$ & & \\
\hline \multirow[t]{2}{*}{ From taxes on financial and capital transactions } & & & & -1.93 & & \\
\hline & & & & $(1.49)$ & & \\
\hline \multirow[t]{2}{*}{ From Non-recurrent taxes on property } & & & & 1.78 & & \\
\hline & & & & $(5.35)$ & & \\
\hline \multicolumn{7}{|l|}{ Tax revenues ( $\%$ of GDP) } \\
\hline \multirow[t]{2}{*}{ Total Tax revenues } & $1.13^{\star \star}$ & $1.13^{\star \star}$ & 0.57 & 0.74 & 0.37 & 0.41 \\
\hline & $(0.45)$ & $(0.45)$ & $(0.55)$ & $(0.73)$ & $(0.63)$ & $(0.71)$ \\
\hline \multicolumn{7}{|l|}{ Technological change \& Globalisation } \\
\hline \multirow[t]{2}{*}{ Ln (openness) } & 0.10 & 0.093 & $0.21^{\star *}$ & $0.21^{*}$ & $0.23^{\star \star \star}$ & $0.24^{\star *}$ \\
\hline & $(0.079)$ & $(0.073)$ & $(0.11)$ & $(0.11)$ & $(0.079)$ & $(0.10)$ \\
\hline \multirow[t]{2}{*}{ Ln (MFP change) } & -0.39 & -0.37 & -0.48 & -0.43 & $-0.43^{*}$ & $-0.47^{\star}$ \\
\hline & $(0.25)$ & $(0.27)$ & $(0.31)$ & $(0.35)$ & $(0.22)$ & $(0.25)$ \\
\hline \multicolumn{7}{|l|}{ Labour market, sociodemographic conditions and earnings inequality } \\
\hline \multirow[t]{2}{*}{ In(Unemployment rate) } & $0.15^{\star \star *}$ & $0.15^{\star \star \star}$ & $0.16^{* * *}$ & $0.13^{\star *}$ & $0.18^{\star \star *}$ & $0.17^{\star \star \star}$ \\
\hline & $(0.042)$ & $(0.044)$ & $(0.054)$ & $(0.052)$ & $(0.029)$ & $(0.040)$ \\
\hline \multirow[t]{2}{*}{ Earnings inequality: $\ln (\mathrm{d} 9 \mathrm{~d} 1)$} & -0.098 & -0.079 & -0.13 & -0.12 & -0.14 & -0.16 \\
\hline & $(0.18)$ & $(0.18)$ & $(0.25)$ & $(0.27)$ & $(0.27)$ & $(0.32)$ \\
\hline \multirow[t]{2}{*}{ Share of workless families with children among working-age households } & 0.41 & 0.45 & -0.051 & -0.70 & -0.33 & -0.069 \\
\hline & $(1.08)$ & $(1.18)$ & $(1.20)$ & $(1.04)$ & $(0.90)$ & $(0.89)$ \\
\hline Time fixed effects & Yes & Yes & Yes & Yes & Yes & Yes \\
\hline Country fixed effects & Yes & Yes & Yes & Yes & Yes & Yes \\
\hline Observations & 344 & 344 & 357 & 357 & 357 & 357 \\
\hline R squared & 0.972 & 0.972 & 0.971 & 0.971 & 0.971 & 0.971 \\
\hline
\end{tabular}

Note: Dependent variable is the natural logarithm of redistribution. Standard errors are clustered at the country level. Results are based on conditional quantile regressions at the median.

Significance levels: $* \mathrm{p}<.1 ; * * \mathrm{p}<.05 ; * * * \mathrm{p}<.01$

Bold highlights significant coefficient 
Table A.24. Transfers and redistribution: a focus on unemployment-related transfers - Median regressions

\begin{tabular}{|c|c|c|c|c|c|c|c|c|c|c|c|c|c|c|}
\hline Dependent variable is $\ln$ (redistribution) & 1 & 2 & 3 & 4 & 5 & 6 & 7 & 8 & 9 & 10 & 11 & 12 & 13 & 14 \\
\hline \multirow{2}{*}{\multicolumn{15}{|c|}{\begin{tabular}{|l} 
Transfer parameters \\
Net unemployment benefit replacement rate (1)
\end{tabular}}} \\
\hline & & & & & & & & & & & & & & \\
\hline \multirow{2}{*}{ Over 5 years - at $100 \%$ of the AW, married couple } & $0.69^{\star \star}$ & & & & & & & $0.31^{*}$ & & & $0.71^{\star \star \star}$ & & & \\
\hline & $(0.32)$ & & & & & & & $(0.18)$ & & & $(0.21)$ & & & \\
\hline \multirow[t]{2}{*}{ Over 5 years - at $150 \%$ of the AW, married couple } & & $0.84^{\star}$ & & & & & & & & & & & & \\
\hline & & $(0.47)$ & & & & & & & & & & & & \\
\hline \multirow[t]{2}{*}{ Over 5 years - at $67 \%$ of the AW, married couple } & & & $0.56^{\star \star}$ & & & & & & $0.23^{*}$ & & & $0.57^{\star \star \star}$ & & \\
\hline & & & $(0.24)$ & & & & & & $(0.14)$ & & & $(0.12)$ & & \\
\hline \multirow[t]{2}{*}{ Initial - at $100 \%$ of the AW, married couple } & & & & 0.19 & & & & & & & & & & \\
\hline & & & & $(0.28)$ & & & & & & & & & & \\
\hline \multirow{2}{*}{ Initial - at $67 \%$ of the AW, married couple } & & & & & 0.067 & & & & & & & & & \\
\hline & & & & & $(0.21)$ & & & & & & & & & \\
\hline \multirow[t]{2}{*}{ Long-term- at $100 \%$ of the AW, married couple } & & & & & & $0.57^{\star \star \star}$ & & & & & & & & \\
\hline & & & & & & $(0.22)$ & & & & & & & & \\
\hline \multirow[t]{2}{*}{ Long-term- at $67 \%$ of the AW, married couple } & & & & & & & $0.50^{\star \star}$ & & & 0.22 & & & $0.37^{\star \star \star}$ & $0.25^{\star \star}$ \\
\hline & & & & & & & $(0.22)$ & & & $(0.16)$ & & & $(0.13)$ & $(0.12)$ \\
\hline \multirow{2}{*}{ Unemployment insurance coverage (2) } & & & & & & & & & & & $0.49^{\star *}$ & $0.45^{*}$ & 0.53 & 0.65 \\
\hline \multirow{2}{*}{\multicolumn{15}{|c|}{ Social spending (in $\%$ of GDP) }} \\
\hline & & & & & & & & & & & & & & \\
\hline \multirow{2}{*}{ Spending on active labour market policies (3) } & & & & & & & & $-9.54^{\star \star}$ & $-10.3^{\star \star}$ & $-12.3^{\star \star \star}$ & & & & $-11.7^{\star \star \star}$ \\
\hline & & & & & & & & $(4.83)$ & $(4.19)$ & $(3.56)$ & & & & $(4.38)$ \\
\hline \multirow{2}{*}{ Total Social spending } & 0.60 & 0.62 & 0.61 & 0.91 & 1.00 & 0.94 & 0.97 & $1.75^{\star \star \star}$ & $1.91^{\star \star \star}$ & $1.94^{\star \star \star}$ & $1.60^{*}$ & $1.27^{\star}$ & $1.47^{\star}$ & 1.57 \\
\hline & $(0.83)$ & $(0.91)$ & $(0.73)$ & "(1.07) & "(0.69) & " $(0.69)$ & $(0.80)$ & $(0.66)$ & $(0.61)$ & $(0.67)$ & $(0.83)$ & $(0.68)$ & $(0.80)$ & $(1.04)$ \\
\hline \multicolumn{15}{|l|}{ Technological change \& Globalisation } \\
\hline \multirow{2}{*}{ Ln (openness) } & $0.19^{\star \star \star}$ & $0.18^{\star \star}$ & $0.17^{\star \star}$ & $0.16^{\star}$ & $0.13^{\star}$ & $0.12^{*}$ & $0.10^{*}$ & 0.088 & 0.093 & 0.075 & 0.028 & -0.010 & -0.017 & 0.063 \\
\hline & $(0.071)$ & $(0.084)$ & $(0.064)$ & ) $(0.086)$ & $(0.071)$ & $(0.063)$ & )$(0.057)$ & $(0.089)$ & $(0.065)$ & $(0.100)$ & $(0.068)$ & $(0.080)$ & $(0.11)$ & $(0.090)$ \\
\hline \multirow[t]{2}{*}{ Ln (MFP change) } & -0.10 & -0.051 & -0.060 & -0.022 & 0.012 & 0.093 & 0.14 & 0.081 & 0.056 & 0.10 & -0.024 & -0.16 & -0.074 & -0.11 \\
\hline & $(0.23)$ & $(0.30)$ & $(0.15)$ & $(0.28)$ & $(0.24)$ & $(0.19)$ & $(0.19)$ & $(0.45)$ & $(0.41)$ & $(0.44)$ & $(0.25)$ & $(0.37)$ & $(0.66)$ & $(0.59)$ \\
\hline \multicolumn{15}{|l|}{ Labour market, sociodemographic conditions and earnings inequality } \\
\hline \multirow[t]{2}{*}{ In (Unemployment rate) } & $0.14^{\star \star \star}$ & $0.14^{\star \star}$ & $0.15^{\star \star \star}$ & * $0.13^{\star \star}$ & $0.13^{\star \star \star}$ & $0.14^{\star \star \star}$ & * $0.15^{\star \star \star}$ & $0.099^{\star \star \star}$ & $0.099^{\star \star \star}$ & $0.091^{\star \star \star}$ & $\star 0.099^{\star \star \star}$ & $0.096^{\star \star \star}$ & 0.12 & $0.15^{\star}$ \\
\hline & $(0.041)$ & $(0.054)$ & )$(0.056)$ & ) & $(0.035)$ & )$(0.042)$ & ) $(0.052)$ & $(0.033)$ & $"(0.032)$ & $"(0.030)$ & $"(0.034)$ & $(0.034)$ & "(0.098) & $(0.091)$ \\
\hline \multirow[t]{2}{*}{ Earnings inequality: $\ln (\mathrm{d} 9 \mathrm{~d} 1$ ) } & $-0.25^{\star}$ & -0.24 & -0.25 & -0.28 & -0.30 & -0.30 & $-0.31^{\star \star}$ & -0.29 & $-0.32^{\star \star}$ & $-0.32^{\star *}$ & $-0.45^{*}$ & $-0.48^{\star}$ & $-0.47^{\star \star \star}$ & $-0.41^{*}$ \\
\hline & $(0.15)$ & $(0.17)$ & $(0.16)$ & $(0.20)$ & (0.19) & $(0.19)$ & $(0.15)$ & $(0.21)$ & $(0.14)$ & $(0.16)$ & $(0.27)$ & $(0.26)$ & $(0.15)$ & $(0.25)$ \\
\hline \multirow[t]{2}{*}{ Share of workless families with children among working-age households } & 0.22 & 0.58 & 0.059 & 1.65 & 1.13 & 0.38 & 0.37 & 0.86 & 0.91 & 1.02 & 1.35 & 1.60 & 1.99 & 0.91 \\
\hline & $(1.27)$ & $(1.95)$ & $(1.44)$ & $(1.61)$ & $(0.83)$ & $(0.99)$ & $(1.08)$ & $(0.71)$ & $(0.70)$ & $(0.97)$ & $(1.18)$ & $(1.08)$ & $(2.00)$ & $(1.67)$ \\
\hline Time fixed effects & Yes & Yes & Yes & Yes & Yes & Yes & Yes & Yes & Yes & Yes & Yes & Yes & Yes & Yes \\
\hline Country fixed effects & Yes & Yes & Yes & Yes & Yes & Yes & Yes & Yes & Yes & Yes & Yes & Yes & Yes & Yes \\
\hline Observations & 304 & 304 & 304 & 304 & 304 & 304 & 304 & 272 & 272 & 272 & 152 & 152 & 152 & 142 \\
\hline R squared & 0.971 & 0.969 & 0.971 & 0.968 & 0.967 & 0.970 & 0.970 & 0.975 & 0.976 & 0.975 & 0.976 & 0.977 & 0.974 & 0.983 \\
\hline
\end{tabular}

Note: Dependent variable is the natural logarithm of redistribution. Standard errors are clustered at the country level. R squared does not incorporate the effect of country fixed effects. (1) Families without children. (2) \% of labour force insured for unemployment risk. (3) Active measures only (categories 10-70).

Significance levels: $* \mathrm{p}<.1 ; * * \mathrm{p}<.05 ; * * * \mathrm{p}<.01$, Bold highlights significant coefficient 
Table A.25. Transfers and redistribution: a focus on public policies for families and children - Median regressions

\begin{tabular}{|c|c|c|c|c|c|c|c|c|c|c|c|c|c|c|}
\hline \multirow{3}{*}{$\begin{array}{l}\text { Dependent variable is In(redistribution) } \\
\text { Policy indicators } \\
\text { Total public spending on families as a share of GDP }\end{array}$} & 1 & 2 & 3 & 4 & 5 & 6 & 7 & 8 & 9 & 10 & 11 & 12 & 13 & 14 \\
\hline & 3.74 & & & & & & & & & & & & & \\
\hline & "(4.52) & & & & & & & & & & & & & \\
\hline \multirow{2}{*}{ Public spending on cash benefits for families as a share of GDP } & & $\begin{array}{r}6.29 \\
(3.99)\end{array}$ & & & & & & & & & & & & \\
\hline & & & 7.96 & & & & & & & & & & & \\
\hline \multirow{2}{*}{ Public spending on tax breaks for families as a share of GDP } & & & (7.17) & & & & & & & & & & & \\
\hline & & & & " $(6.87)$ & & & & & & & & & & \\
\hline Public spending on early childhood education and care as a share of GDP & & & & & $\begin{array}{l}13.7 \\
(9.05)\end{array}$ & & & & & & & & & \\
\hline Length of paid maternity leave & & & & & & 0.058 & & & & & & & & \\
\hline \multirow{2}{*}{$\begin{array}{l}\text { Length of paid paternity leave } \\
\text { Proportional difference in net transfers by single and equal-dual earner couples, household earnings at } 133 \% \text { of the AW }\end{array}$} & & & & & & & 0.084 & & & & & & & \\
\hline & & & & & & & $(0.096)$. & & & & & & & \\
\hline \multirow{2}{*}{ Proportional difference in net transfers by single and equal-dual earner couples, household earnings at $200 \%$ of the AW } & & & & & & & & $(0.00086)$ & & & & & & \\
\hline & & & & & & & & & $\begin{array}{l}-0.38 \\
(0.75)\end{array}$ & & & & & \\
\hline \multirow{2}{*}{$\begin{array}{l}\text { Labour market situation of women } \\
\text { Gender-gap in the full-time equivalent employment to population ratio }\end{array}$} & & & & & & & & & & & & & & \\
\hline & & & & & & & & & & - $-1.43^{*+4 *}$ & & & & \\
\hline Employment rate of mothers & & & & & & & & & & & 0.47 & & & \\
\hline \multirow[t]{2}{*}{ Employment rate of partnered mothers } & & & & & & & & & & & & 0.49 & & \\
\hline & & & & & & & & & & & & $(0.43)$ & -0.016 & \\
\hline $\begin{array}{l}\text { Employment rate of sole-parents mothers } \\
\text { Women employment rate }\end{array}$ & & & & & & & & & & & & & $(0.15)$ & \\
\hline & & & & & & & & & & & & & & 0.27 \\
\hline $\begin{array}{l}\text { Social spending (in\% of GDP) } \\
\text { Total Social spending }\end{array}$ & $\begin{array}{l}0.00055 \\
(0.87)\end{array}$ & $(1.01)$ & $(0.60)$ & $=0.63$ & $\begin{array}{ll}1.56^{*} \\
(0.81)\end{array}$ & {$\left[\begin{array}{l}1.00 \\
(0.82)\end{array}\right.$} & $\begin{array}{c}1.19 \\
(0.85)\end{array}$ & $\begin{array}{c}1.12 \\
(0.80)\end{array}$ & $=1.36$ & 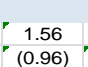 & $2.10^{* \star \star}$ & 2.10.68) & $\left(\begin{array}{ll}1.84^{* *} \\
(0.75)\end{array}\right.$ & $\begin{array}{l}\mathbf{1 . 6 2} 2^{\star} \\
(0.95)\end{array}$ \\
\hline \multirow{2}{*}{$\begin{array}{l}\text { Technological change \& Globalisation } \\
\text { Ln (openness) }\end{array}$} & & & & & & & & & & & & & & \\
\hline & $\begin{aligned} 0.15 \\
(0.12)\end{aligned}$ & & $=0.098)$ & $=0.18$ & $\frac{0.21 \times}{(0.082)}$ & $(0.10)$ & {$\left[\begin{array}{ll}0.13 \\
(0.11)\end{array}\right.$} & $\begin{array}{l}0.14 \\
(0.093)\end{array}$ & $=0.16$ & $(0.10)$ & $=0.077)$ & $=0.091)$ & 0.08 & $=0.10$ \\
\hline Ln (MFP change) & $-0.62^{*+*}$ & -0.22 & -0.13 & -0.51 & $=-0.15$ & $=-0.36$ & -0.38 & 0.035 & $0.20:$ & {$\left[\begin{array}{ll}-0.23 \\
0\end{array}\right.$} & 0.052 & 0.13 & 0.091 & $=-0.22$ \\
\hline \multirow{2}{*}{$\begin{array}{l}\text { Labour market, sociodemographic conditions and earnings inequality } \\
\text { In (Unemployment rate) }\end{array}$} & & & & & & & & & & & & & & \\
\hline & $0.15^{* * *}$ & $0.096^{*}$ & $0.13^{* \star \star}$ & $0.14^{\star \star \star *}$ & $0.100^{\star \star}$ & $0.12^{\text {** }}$ & $0.12^{\star \star *}$ & $0.14^{\star \star \star * *}$ & $0.12^{\star \star \star}$ & 0.029 & $0.11^{\star \star \star}$ & & $0.11^{+* \pm *}$ & $0.12^{\star * *}$ \\
\hline \multirow{2}{*}{ Earnings inequality: In (d9d1) } & -0.24 & $-0.29^{\star \star}$ & -0.30 & -0.22 & $-0.33^{\star+}$ & -0.31 & -0.28 & -0.25 & $-0.30^{*}$ & $-0.24^{*}$ & -0.087 & $-0.060^{\circ}$ & -0.074 & $-0.32^{* \star}$ \\
\hline & $:(0.37)$ & $(0.13)$ & $(0.19)$ & $(0.26)$ & $(0.14)$ & ; $(0.24)$ & {$\left[(0.23)^{n}\right.$} & $(0.18)$ & $(0.18)$ & {$[0.10)$} & & & & $(0.14)$ \\
\hline \multirow{2}{*}{ Share of workless families with children among working-age households } & 1.12 & 0.44 & 1.16 & 0.54 & 1.11 & 0.52 & 0.49 & $1.53^{*}$ & 1.31 & 0.16 & 0.73 & 0.77 & 0.97 & 0.86 \\
\hline & $\frac{(1.02)}{\text { Yes }}$ & (0.73) & $\frac{(0.95)}{\text { Yes }}$ & $\frac{(1.33)}{\text { Yes }}$ & $\begin{array}{l}(1.36) \\
\text { Yes }\end{array}$ & (0.82) & (0.70) & $(0.83)$ & $(1.51)^{n}$ & $\frac{(0.79)}{Y e s}$ & $\frac{(0.68)}{Y)^{\prime}}$ & $(0.79)$ & $\frac{(1.09)}{Y_{0}}$ & (0.79) \\
\hline Country fixed effects & Yes & Yes & Yes & $\begin{array}{l}\text { Yes } \\
\text { Yes }\end{array}$ & $\begin{array}{l}\text { Yres } \\
\text { Yes }\end{array}$ & $\begin{array}{l}\text { Yes } \\
\text { Yes }\end{array}$ & $\begin{array}{l}\text { Yes } \\
\text { Yes }\end{array}$ & $\begin{array}{l}\text { Yes } \\
\text { Yes }\end{array}$ & $\begin{array}{l}\text { Yes } \\
\text { Yes }\end{array}$ & $\begin{array}{l}\text { Yes } \\
\text { Yes }\end{array}$ & $\begin{array}{l}\text { Yes } \\
\text { Yes }\end{array}$ & $\begin{array}{l}\text { Yes } \\
\text { Yes }\end{array}$ & $\begin{array}{l}\text { Yes } \\
\text { Yes }\end{array}$ & Yes \\
\hline Observations & 178 & 329 & 280 & 179 & 293 & 320 & 320 & 304 & 304 & 304 & 263 & 254 & 254 & 356 \\
\hline R squared & 0.984 & 0.970 & 0.973 & 0.983 & 0.972 & 0.964 & 0.964 & 0.967 & 0.968 & 0.965 & $0.969^{2}$ & 0.970 & 0.971 & 0.969 \\
\hline
\end{tabular}

Note: Dependent variable is the natural logarithm of redistribution. Standard errors are clustered at the country level. Results are based on conditional quantile regressions at the median.

Significance levels: $* \mathrm{p}<.1 ; * * \mathrm{p}<.05 ; * * * \mathrm{p}<.01$

Bold highlights significant coefficients 
Table A.26. The effects of old-age pension systems and early retirement incentives on redistribution to the working-age population - Median regressions

\begin{tabular}{|c|c|c|c|c|c|c|c|c|c|c|c|c|c|}
\hline Dependent variable is $\ln$ (redistribution) & 1 & 2 & 3 & 4 & 5 & 6 & 7 & 8 & 9 & 10 & 11 & 12 & 13 \\
\hline \multicolumn{14}{|l|}{ Old-age pension parameters (1) } \\
\hline \multirow[t]{2}{*}{ Normal retirement age } & -0.0077 & & & & & & & & & & & & \\
\hline & $(0.011)$ & & & & & & & & & & & & \\
\hline \multirow[t]{2}{*}{ Normal retirement age, men } & & -0.0019 & & & & & & & & & & & \\
\hline & & '(0.0060) & & & & & & & & & & & \\
\hline \multirow[t]{2}{*}{ Normal retirement age, women } & & & -0.0077 & & & & & & & & & & \\
\hline & & & $(0.011)$ & & & & & & & & & & \\
\hline \multirow[t]{2}{*}{ Minimum retirement age } & & & & $0.013^{\star \star \star}$ & & & & & & & & & \\
\hline & & & & '(0.0048) & & & & & & & & & \\
\hline \multirow[t]{2}{*}{ Minimum retirement, men } & & & & & $0.013^{\star \star \star}$ & & $0.015^{\star \star \star}$ & $\star 0.013^{\star \star \star}$ & $0.015^{\star \star \star}$ & * $0.018^{\star \star}$ & $0.014^{\star \star \star}$ & & \\
\hline & & & & & '(0.0041) & & $(0.0048)$ & ) $(0.0031)$ & $(0.0036)$ & ) $(0.0070)$ & )$^{\prime}(0.0034)$ & & \\
\hline \multirow[t]{2}{*}{ Minimum retirement, women } & & & & & & 0.0073 & & & & & & & \\
\hline & & & & & & $"(0.013)$ & & & & & & & \\
\hline \multirow[t]{2}{*}{ Replacement rate from the old-age pension system at age 60 (2) } & & & & & & & 0.041 & & & & & & \\
\hline & & & & & & & $(0.045)$ & & & & & & \\
\hline \multirow{2}{*}{ Replacement rate from the old-age pension system at age 65 (2) } & & & & & & & & $0.10^{\star \star \star}$ & & & & & \\
\hline & & & & & & & & $(0.033)$ & & & & & \\
\hline \multirow[t]{2}{*}{ Replacement rate from the old-age pension system at age 69 (2) } & & & & & & & & & 0.27 & & & & \\
\hline & & & & & & & & & $(0.36)$ & & & & \\
\hline \multirow[t]{2}{*}{ Replacement rate from the old-age pension system between ages $60 \& 65$ (average) (2) } & & & & & & & & & & 0.070 & & & \\
\hline & & & & & & & & & & $(0.085)$ & & & \\
\hline Replacement rate from the old-age pension system between ages $65 \& 69$ (average) (2) & & & & & & & & & & & 0.17 & & \\
\hline \multirow{2}{*}{\multicolumn{14}{|c|}{ Effective retirement age }} \\
\hline \multirow{2}{*}{ Average effective retirement age, men } & & & & & & & & & & & & & \\
\hline & & & & & & & & & & & & $r(0.011)$ & \\
\hline \multirow[t]{2}{*}{ Average effective retirement age, women } & & & & & & & & & & & & & -0.0015 \\
\hline & & & & & & & & & & & & & '(0.0098) \\
\hline \multicolumn{14}{|l|}{ Social spending (in $\%$ of GDP) } \\
\hline Social spending on old-age population & $\begin{array}{l}1.64 \\
(2.63)\end{array}$ & $\begin{array}{l}1.47 \\
(2.56)\end{array}$ & $\begin{array}{l}1.51 \\
(2.96)\end{array}$ & 2.13 & 1.91 & $(2.79)$ & $\frac{1.20}{(3.81)}$ & 2.03 & 0.85 & 0.96 & $\begin{array}{c}1.62 \\
(2.14)\end{array}$ & $(-1.44$ & $\begin{array}{l}-1.29 \\
(2.53)\end{array}$ \\
\hline Total Social spending & 1.99 & 1.98 & 2.17 & 2.18 & 2.28 & 2.17 & 2.37 & 2.06 & 2.29 & 2.37 & $2.17^{*}$ & 2.27 & $2.37^{\star}$ \\
\hline & "(1.25) & $(1.44)$ & (1.49) & $(1.96)$ & "(1.92) & $(1.60)$ & (2.28) & "(1.67) & (1.53) & "(1.72) & $(1.22)$ & (2.10) & $(1.40)$ \\
\hline Technological change \& Globalisation & & & & & & & & & & & & & \\
\hline Ln (openness) & 0.24 & $0.17^{\star}$ & 0.25 & 0.20 & 0.20 & 0.17 & 0.18 & $0.19^{* *}$ & 0.15 & 0.17 & $0.18^{\text {** }}$ & 0.12 & 0.088 \\
\hline Ln (MFP change) & $=0.14$ & $(0.090)$ & (0.18) & $(0.14)$ & (0.13) & $(0.11)$ & $(0.14)$ & $(0.092)$ & $(0.099)$ & $(0.12)$ & $(0.078)$ & $(0.19)$ & $(0.088)$ \\
\hline & $\begin{array}{l}-0.14 \\
(0.22)\end{array}$ & $\begin{aligned}-0.042 \\
(0.20)\end{aligned}$ & -0.085 & $\begin{array}{l}0.062 \\
(0.19)\end{array}$ & 0.085 & $(0.037$ & $\begin{array}{l}0.061 \\
(0.25)\end{array}$ & $\begin{array}{l}0.057 \\
(0.16)\end{array}$ & 0.050 & .0 .080 & 0.040 & -0.19 & $\begin{array}{l}-0.18 \\
(0.23)\end{array}$ \\
\hline Labour market, sociodemographic conditions and earnings inequality & & & & & & & & & & & & & \\
\hline Share of 55-65 in working-age population & -1.25 & -1.36 & -1.05 & -1.56 & -1.50 & -1.42 & -1.36 & $-2.03^{*}$ & $-1.79^{* *}$ & -1.58 & -1.94 & -0.018 & -0.038 \\
\hline & $(1.11)$ & $(0.99)$ & $(1.38)$ & $(1.13)$ & $(1.12)$ & $(0.86)$ & $(1.79)$ & $(1.17)$ & $(0.82)$ & $(1.19)$ & $(1.18)$ & $(1.68)$ & $(1.18)$ \\
\hline Old-age dependency ratio & -0.85 & -1.11 & -0.92 & -1.57 & -1.58 & $-1.43^{*}$ & -1.18 & $-1.56^{\star}$ & -1.45 & -1.40 & -1.43 & -0.22 & -0.11 \\
\hline & $(1.03)$ & $(0.92)$ & $(1.04)$ & $(1.02)$ & $(0.99)$ & $(0.84)$ & $(1.18)$ & $(0.81)$ & $(0.98)$ & $(1.06)$ & $(0.87)$ & $(2.00)$ & $(0.91)$ \\
\hline In (Unemployment rate) & 0.043 & 0.059 & 0.044 & 0.034 & 0.034 & 0.046 & 0.044 & 0.038 & 0.040 & 0.049 & 0.039 & 0.11 & $0.090^{*}$ \\
\hline & $(0.064)$ & $(0.045)$ & $(0.068)$ & (0.039) & ' & $"(0.039)$ & ) (0.039) & ' & "(0.045) & ' & "(0.039) & ) '(0.12) & $(0.054)$ \\
\hline Earnings inequality: In (d9d1) & -0.31 & -0.19 & -0.28 & -0.12 & -0.14 & -0.11 & -0.17 & -0.16 & -0.20 & -0.12 & -0.18 & -0.29 & $-0.33^{\star \star}$ \\
\hline & $(0.28)$ & $(0.21)$ & $(0.27)$ & $(0.18)$ & $(0.16)$ & $(0.17)$ & $(0.25)$ & $(0.16)$ & $(0.20)$ & $(0.21)$ & $(0.18)$ & $(0.25)$ & $(0.16)$ \\
\hline Share of workless families with children among working-age households & 1.02 & 0.93 & 0.79 & 1.04 & 0.97 & 1.01 & 0.87 & 0.85 & 0.98 & 0.73 & 0.97 & 0.71 & 0.80 \\
\hline & $(1.13)$ & $(0.86)$ & $(1.42)$ & $(0.79)$ & $(0.91)$ & $(0.84)$ & $(1.05)$ & $(0.74)$ & $(0.98)$ & $(0.77)$ & $(0.90)$ & $(1.83)$ & $(0.78)$ \\
\hline Time fixed effects & Yes & Yes & Yes & Yes & Yes & Yes & Yes & Yes & Yes & Yes & Yes & Yes & Yes \\
\hline Country fixed effects & Yes & Yes & Yes & Yes & Yes & Yes & Yes & Yes & Yes & Yes & Yes & Yes & Yes \\
\hline Observations & 233 & 233 & 233 & 229 & 229 & 229 & 229 & 229 & 229 & 229 & 229 & 327 & 327 \\
\hline R squared & 0.926 & 0.923 & 0.925 & 0.926 & 0.926 & 0.925 & 0.928 & 0.928 & 0.931 & 0.927 & 0.930 & 0.968 & 0.967 \\
\hline
\end{tabular}

Note: Dependent variable is the natural logarithm of redistribution. Standard errors are clustered at the country level. (1) Legal age conditions for someone who enters the labour market at age 25 and exclude minimum contribution period conditions. The idea is to use legal ages that are referred to in public as the typical retirement ages. (2) Men. Excluding any kind of benefit received from unemployment benefit schemes or disability pension schemes. Results are based on conditional quantile regressions at the median.

Significance levels: $* \mathrm{p}<.1 ; * * \mathrm{p}<.05 ; * * * \mathrm{p}<.01$

Bold highlights significant coefficient 